\title{
Paleoceanography
}

\section{RESEARCH ARTICLE \\ 10.1002/2016PA003028 \\ Anatomy of Heinrich Layer 1 and its role in the last deglaciation}

Key Points:

- Heinrich Layer 1 is represented by a double peak in the central North Atlantic

- Best estimates for the ages of the two peaks are $\sim 16.1$ (H1.1) and $\sim 15 \mathrm{ka}$ (H1.2)

- Heinrich Event 1 cannot account for cooling and weakened AMOC during early Heinrich Stadial 1 ( 20-16.1 ka)

Supporting Information:

- Supporting Information S1

- Movie S1

- Movie S2

- Figure S1

- Figure S2

- Figure S3

Correspondence to:

D. A. Hodell,

dah73@cam.ac.uk

\section{Citation:}

Hodell, D. A., et al. (2017), Anatomy of Heinrich Layer 1 and its role in the last deglaciation, Paleoceanography, 32, 284-303, doi:10.1002/2016PA003028.

Received 29 AUG 2016 Accepted 8 MAR 2017

Accepted article online 15 MAR 2017

Published online 30 MAR 2017

C2017. American Geophysical Union. All Rights Reserved.

\section{Introduction} North Atlantic, to $<1 \mathrm{~cm}$ in the east [Dowdeswell et al., 1995].

\author{
David A. Hodell' (D), Joseph A. Nicholl ${ }^{1}$ (D), Tomaso R. R. Bontognali ${ }^{2}$, Steffan Danino ${ }^{3}$ (D, \\ Javier Dorador 4 (D), Julian A. Dowdeswell ${ }^{3}$, Joshua Einsle ${ }^{1}$ iD, Holger Kuhlmann ${ }^{5}$ (D), \\ Belen Martrat $^{6}$ (D, Maryline J. Mleneck-Vautravers ${ }^{1}$, Francisco Javier Rodríguez-Tovar ${ }^{4}$ iD, \\ and Ursula Röhl ${ }^{5}$ in
}

${ }^{1}$ Godwin Laboratory for Palaeoclimate Research, Department of Earth Sciences, University of Cambridge, Cambridge, UK, ${ }^{2}$ Geological Institute and Institute of Geochemistry and Petrology, ETH Zurich, Zurich, Switzerland, ${ }^{3}$ Scott Polar Research Institute, Department of Geography, University of Cambridge, Cambridge, UK, ${ }^{4}$ Departamento de Estratigrafía y Paleontología, Universidad de Granada, Granada, Spain, ${ }^{5}$ MARUM-Center for Marine Environmental Sciences, University of Bremen, Bremen, Germany, ${ }^{6}$ Department of Environmental Chemistry, Institute of Environmental Assessment and Water Research (IDÆA), Spanish Council for Scientific Research (CSIC), Barcelona, Spain

Abstract X-ray fluorescence (XRF) core scanning and X-ray computed tomography data were measured every $1 \mathrm{~mm}$ to study the structure of Heinrich Event 1 during the last deglaciation at International Ocean Discovery Program Site U1308. Heinrich Layer 1 comprises two distinct layers of ice-rafted detritus (IRD), which are rich in detrital carbonate (DC) and poor in foraminifera. Each DC layer consists of poorly sorted, coarse-grained clasts of IRD embedded in a dense, fine-grained matrix of glacial rock flour that is partially cemented. The radiocarbon ages of foraminifera at the base of the two layers indicate a difference of $1400{ }^{14} \mathrm{C}$ years, suggesting that they are two distinct events, but the calendar ages depend upon assumptions made for surface reservoir ages. The double peak indicates at least two distinct stages of discharge of the ice streams that drained the Laurentide Ice Sheet through Hudson Strait during HE1 or, alternatively, the discharge of two independent ice streams containing detrital carbonate. Heinrich Event 1.1 was the larger of the two events and began at $\sim 16.2 \mathrm{ka}(15.5-17.1 \mathrm{ka})$ when the polar North Atlantic was already cold and Atlantic Meridional Overturning Circulation (AMOC) weakened. The younger peak (H1.2) at 15.1 ka (14.3 to $15.9 \mathrm{ka}$ ) was a weaker event than $\mathrm{H} 1.1$ that was accompanied by minor cooling. Our results support a complex history for Heinrich Stadial 1 (HS1) with reduction in AMOC during the early part ( 20-16.2 ka) possibly driven by melting of European ice sheets, whereas the Laurentide Ice Sheet assumed a greater role during the latter half $(\sim 16.2-14.7 \mathrm{ka})$.

Heinrich layers (HLs) in North Atlantic sediments are formed from massive discharges of the Hudson Strait ice stream that drained the Laurentide Ice Sheet [Heinrich, 1988; Bond et al., 1992; Broecker et al., 1992; Hemming, 2004]. These layers are identified in North Atlantic sediment cores by poorly sorted sediments that are almost devoid of foraminifera and contain large amounts of ice-rafted detritus (IRD), which is rich in detrital carbonate (DC) sourced from Paleozoic limestone and dolostone from the region of Hudson Bay and Hudson Strait [Broecker et al., 1992]. The layers are found from the Labrador Sea in the western Atlantic to off the coast of Portugal in the eastern North Atlantic along a zonal axis between 40 and $50^{\circ} \mathrm{N}$ in the so-called "Ruddiman IRD belt" [Ruddiman, 1977]. The deposits thin eastward from $40-70 \mathrm{~cm}$ in the Labrador Sea to $<5 \mathrm{~cm}$ in the central

Although Heinrich layers were first identified in the open North Atlantic [Heinrich, 1988], they have been correlated with detrital carbonate deposits from the Labrador Sea [Andrews and Tedesco, 1992; Stoner et al., 1996]. Deposits close to Hudson Strait show a more complete history of Heinrich layers but are affected by depositional processes other than ice rafting [Hesse et al., 2004; Rashid et al., 2012; Hesse, 2016]. The complexity of the deposits is related to the release of subglacial meltwater that entrains sediment, triggering the transport of fine material within nepheloid flows and turbidity currents [Hesse and Khodabakhsh, 1998, 2016; Rashid et al., 2003, 2012]. Such flows provide an additional mechanism for the delivery of detrital to the deep sea, resulting in several different types of deposits in the Labrador Sea [Hesse, 2016].

In distal deposits in the open North Atlantic, Heinrich layers consist mainly of IRD and are almost devoid of planktonic foraminifera [Heinrich, 1988; Broecker et al., 1992]. Rashid et al. [2003] suggested that distal 


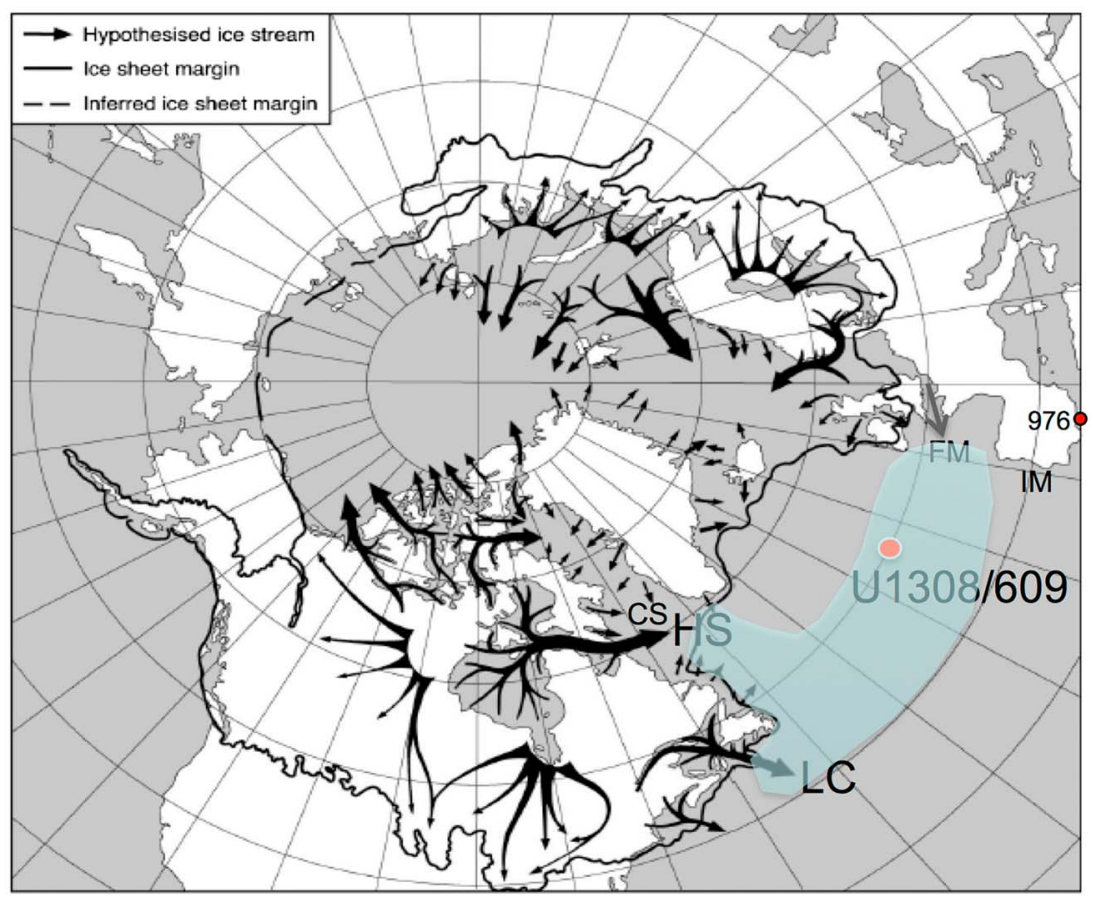

Figure 1. Location of Site U1308 in the IRD belt (blue shade) relative to reconstructed ice sheet extent in the Northern Hemisphere (continuous solid black line) showing the inferred locations of ice streams (black arrows; after Denton and Hughes [1981]) at the Last Glacial Maximum. HS = Hudson Strait; CS = Cumberland Sound; LC = Laurentian Channel; and FM = Fleuve Manche. Figure modified after Stokes and Clark [2001]. Also shown is the Iberian Margin (IM) and location of Site 976.

events are recorded as a single IRD layer that corresponds to only part of the sequence found in cores proximal to Hudson Strait. However, some detailed studies of distal HEs have suggested that the events may be more complex than a single episode of ice rafting. For example, a record of IRD from the Iberian Margin shows two distinct peaks in IRD during HE1 (i.e., H1a and H1b) [Bard et al., 2000], although only the older of these peaks contains DC ( $\mathrm{H} 1 \mathrm{~b})$. The younger H1a contains hematite-coated grains (3\%) but almost no detrital carbonate. On the Laurentian Fan, Gil et al. [2015] identified two ice-rafting events during H1 that are associated with strong cooling and expansion of sea ice. Similar to the Iberian Margin, the older peak is rich in detrital carbonate and the younger is rich in hematite-stained grains.

Here we examined the detailed structure of Heinrich Stadial 1 at International Ocean Discovery Program (IODP) Site U1308 $\left(49^{\circ} 52.6661^{\prime} \mathrm{N} ; 24^{\circ} 14.2875^{\prime} \mathrm{W}\right)$ (Figure 1), which is located within the ice-rafted detritus (IRD) belt of the North Atlantic [Ruddiman, 1977]. Site U1308 represents the reoccupation of DSDP Site 609 , which has played an important role in the recognition of Heinrich events and correlation of millennial-scale climate variability between marine sediment and Greenland ice cores [Broecker et al., 1992; Bond et al., 1992, 1993, 1999; McManus et al., 1994; Bond and Lotti, 1995].

Site U1308 is located $2800 \mathrm{~km}$ from the mouth of Hudson Strait and represents a distal location for deposition by icebergs originating from the Labrador Sea. Heinrich layers are relatively thin in distal deposits, and consequently, bioturbation can easily blur the signal or obliterate internal structure of the event. To assess stratigraphic integrity and resolution, we used X-ray computed tomography (X-ray CT) to conduct a detailed analysis of sediment structure and bioturbation by examining $1 \mathrm{~mm}$ slices of cores from multiple holes at Site U1308. Core scanning XRF was conducted at $1 \mathrm{~mm}$ in Holes U1308A, U1308B, and U1308C, and discrete samples at $5 \mathrm{~mm}$ intervals were taken from Hole U1308A for IRD and foraminiferal point counting, faunal assemblages, mineralogy (X-ray diffraction, XRD), and stable isotope analysis.

\section{Heinrich Terminology}

The literature is confounded by different usages of the terms Heinrich layer (HL), Heinrich event (HE), and Heinrich stadial (HS). Following suggestions from other authors [Barker et al., 2009; Sanchez Goñi and 


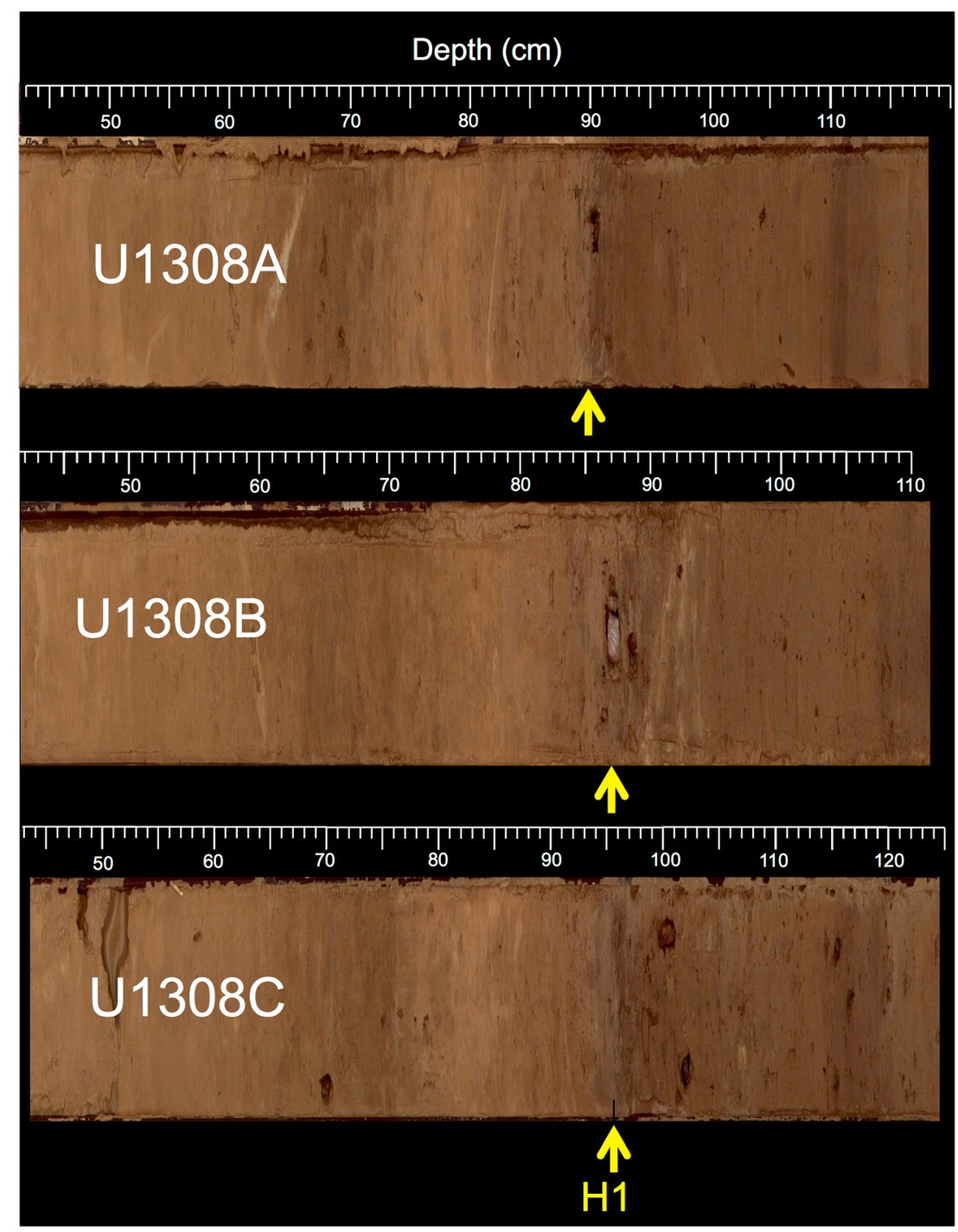

Figure 2. Images of Core 1, Section 1 from Holes U1308A, U1308B, and U1308C. Yellow arrows indicate the base of Heinrich Layer $1(\mathrm{H} 1)$. The dark layer below $\mathrm{H} 1$ is rich in manganese.

Harrison, 2010], we adopt consistent definitions and usage of these terms throughout this paper as described below. A Heinrich event (sensu stricto) is the climate event produced by a massive discharge of the Laurentide Ice Sheet through Hudson Strait. Heinrich events occurred during some but not all stadials, which were part of millennial-scale Dansgaard-Oeschger (D-O) oscillations during the last glaciation. A Heinrich layer is the physical manifestation of a Heinrich event preserved in a marine sediment core. A Heinrich stadial is the cold period that contains the Heinrich event. For the last deglaciation, Heinrich Stadial 1 is synonymous with the "Mystery Interval" (17.5 to $14.5 \mathrm{ka}$ ) [Broecker and Barker, 2007]. A Heinrich event and Heinrich stadial are not the same because Heinrich events are shorter in duration than the Heinrich stadials in which they occur.

\section{Results}

\subsection{Core Images}

Heinrich Layer 1 was recovered in IODP Holes U1308A, U1308B, and U1308C and in two holes at DSDP Site 609. All core images show similar features including a sharp color contrast at the base (Figure 2 and supporting information), representing the contact between light colored carbonate-rich sediment of the 


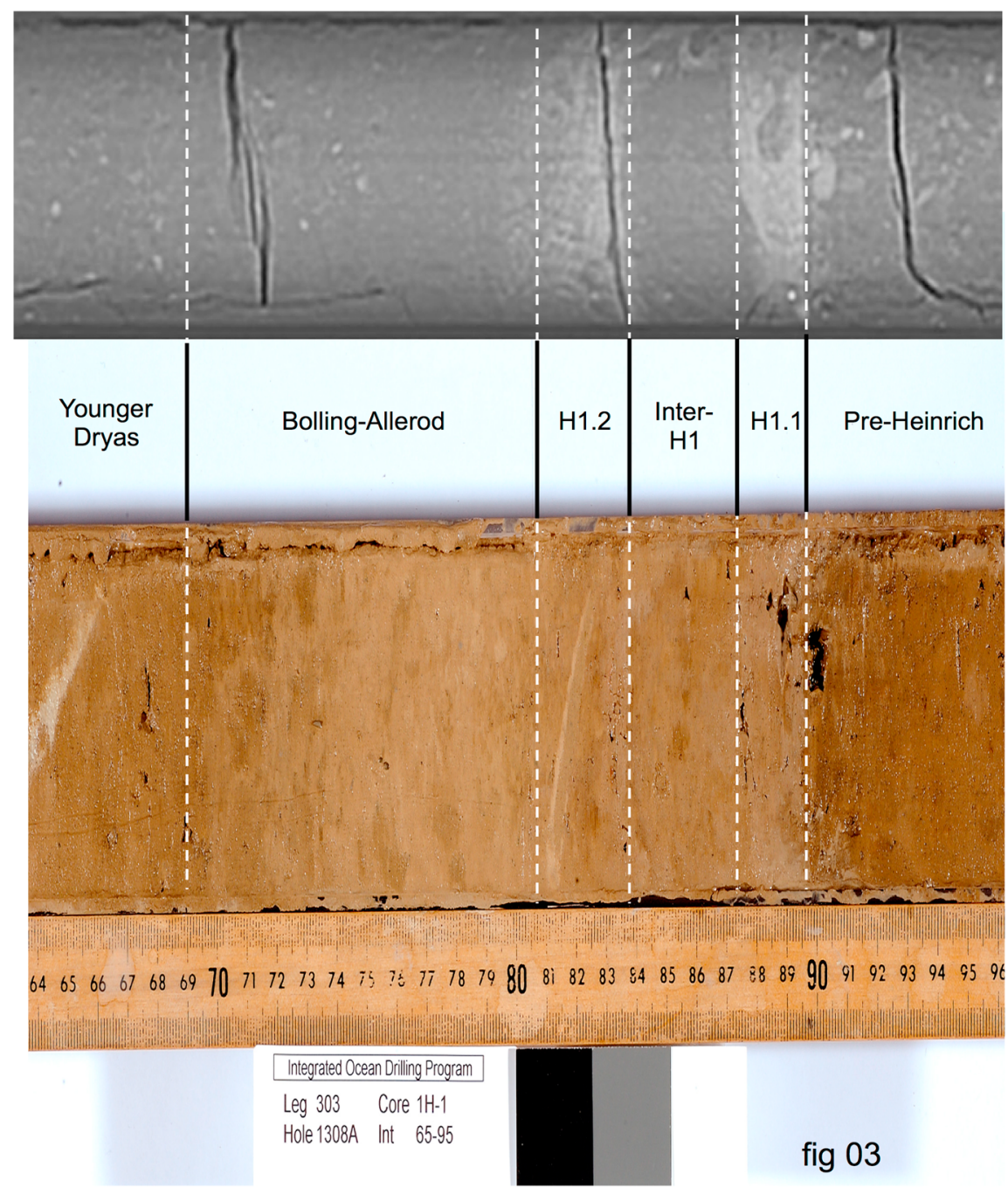

Figure 3. X-ray CT and split core images of Section U1308A-1H-1 showing the various climatic subdivisions of the core.

Heinrich layer and a dark layer below that is rich in manganese. Heinrich Layer 1 is overlain by lighter colored sediments deposited during the Bølling-Allerød (B-A) followed by a transition to the Younger Dryas (Y-D).

\subsection{X-Ray CT Images}

X-ray CT images were acquired for Holes U1308A and U1308B (see supporting information) but could not be obtained for U1308C because of heavy sampling of both archive and working halves of the core. The CT images reflect density contrasts such that ice-rafted detritus has a greater density than the background pelagic sediments that consists mostly of nannofossil ooze and clay [Expedition 303 Scientists, 2006]. Two dense layers are distinctly visible in the CT scan of Hole U1308A, whereas a single mixed layer occurs in Hole U1308B (Figure 3 and supporting information). We refer to the lower peak as $\mathrm{H} 1.1$ and the upper peak as $\mathrm{H} 1.2$ to distinguish them from $\mathrm{H} 1 \mathrm{a}$ and $\mathrm{H} 1 \mathrm{~b}$ defined by Bard et al. [2000] because we are not certain they represent the same events. Each Heinrich layer is poorly sorted, consisting of coarse-grained clasts of IRD embedded in a dense fine-grained matrix. Some large millimeter-sized clasts of IRD are visible in the dark layers immediately below the base of the Heinrich layer in both holes.

Density was calculated for each $1 \mathrm{~mm}$ X-ray CT slice in Hole U1308 by averaging the gray scale of all pixels after removing holes and cracks from each slice (Figure 4; see supporting information). In Hole U1308B, the lower layer is up to $2 \mathrm{~cm}$ thick, whereas the upper layer is $1 \mathrm{~cm}$ thick and the top is bioturbated. The layers also correspond to increases in wet bulk density of the core measured during Expedition 303 by gamma ray attenuation (GRA), which reaches $1.8 \mathrm{~g} \mathrm{~cm}^{-3}$ in each of the two peaks of $\mathrm{H} 1$ in Hole U1308A (Figure 4) 


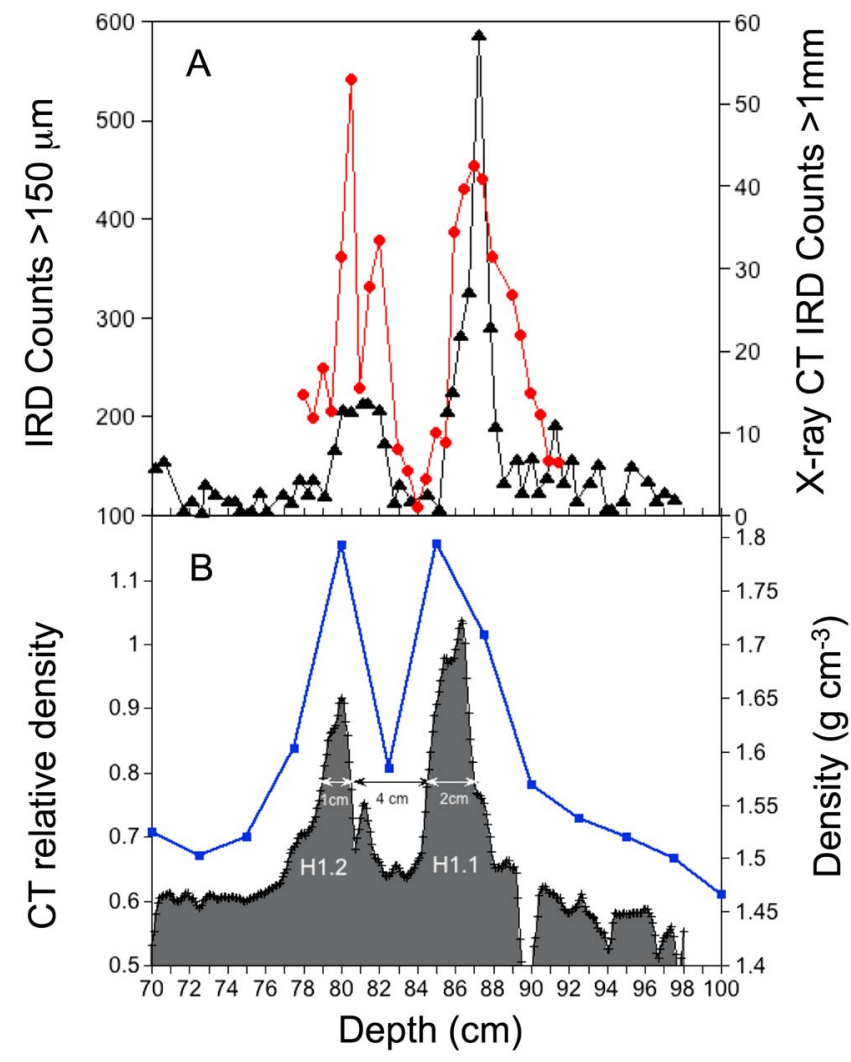

Figure 4. (a) Comparison of IRD point counts from the $>150 \mu \mathrm{m}$ fraction (black) and IRD $>1 \mathrm{~mm}$ estimated by image analysis of the $\mathrm{X}$-ray $\mathrm{CT}$ images (red). (b) Density estimated by CT core scanner (filled gray area) and gamma ray attenuation (blue) for Section U1308A-1H-1 between 70 and $100 \mathrm{~cm}$. The sediment thicknesses at half peak of $\mathrm{H} 1.1$ and 1.2 and the intervening interval are indicated.
[Expedition 303 Scientists, 2006]. The GRA was measured at $2.5 \mathrm{~cm}$ intervals in Hole U1308A, and the peaks are defined by single points, and fine-scale structure is not captured.

The number of grains of IRD in the CT images was automatically counted using FIJ (ImageJ) software [Schindelin et al., 2012] by thresholding each $1 \mathrm{~mm}$ slice to exclude fine-grained, lowdensity matrix sediment and isolate individual IRD grains (Figure 4). IRD grains ( $>1 \mathrm{~mm}$ in size) that were large enough to cross images consisting of $1 \mathrm{~mm}$ slices were counted. Grains were counted using a plug-in for FIJI called BoneJ [Doube et al., 2010], which hosts an object counter called Particle Analyzer. The plug-in is extremely efficient at quantifying the particles in an image stack but only recognizes particles that span more than one image (i.e., $>1 \mathrm{~mm}$ in size). IRD counts were binned in $5 \mathrm{~mm}$ intervals so that they could be compared with actual counts of IRD obtained from the $>150 \mu \mathrm{m}$ fraction in discrete samples taken every $5 \mathrm{~mm}$ (see section 3.4). The pattern of the automated grain counts of $>1 \mathrm{~mm}$ shows two distinct peaks as do the IRD counts from the $>150 \mu \mathrm{m}$ fraction (Figure 4).

\subsection{X-Ray Fluorescence Core Scanning}

The quality of XRF data is highly dependent on the physical properties of the sediment core (e.g., varying porosity) [Grützner and Higgins, 2010; Röhl and Abrams, 2000] and condition of the split core sediment surface and is affected by mineral heterogeneities and surface roughness [Tjallingii et al., 2007]. This is particularly problematic for sediment containing IRD because a single grain at the surface can cause large anomalies in elemental variations. Comparison of XRF scans in multiple holes is necessary to evaluate the reproducibility and integrity of the XRF results.

Hodell et al. [2008] demonstrated that $\mathrm{Ca} / \mathrm{Sr}$ is a reliable proxy for the concentration of detrital carbonate at Site U1308. HL1 is marked by increases in $\mathrm{Ca} / \mathrm{Sr}$ in all three holes, but subtle differences exist in the structure of the signal among holes (Figure 5). In Hole U1308A, HL1 consists of two sharp peaks in Ca/Sr corresponding with the density peaks in the $\mathrm{CT}$ images. The lower, older $(\mathrm{H} 1.1)$ peak is the stronger of the two and is about $2 \mathrm{~cm}$ wide, whereas the upper, younger $(\mathrm{H} 1.2)$ peak is $1 \mathrm{~cm}$ wide. The two peaks are separated by about $3 \mathrm{~cm}$ of intervening sediment that contains no detrital carbonate. In Hole U1308B, HL1 consists of a single diffuse $\mathrm{Ca} / \mathrm{Sr}$ peak that is spread over $7 \mathrm{~cm}$. In Hole U1308C, HL1 consists of two peaks including a larger older peak and smaller second peak separated by less than a centimeter of sediment. The second peak is much weaker and less well defined in Hole U1308C than it is in U1308A. There is also some indication that HL 2 may be double peaked (Figure 5), but we have not studied this event in any detail.

$\mathrm{Si} / \mathrm{Sr}$ reflects the relative contribution of silicate-rich IRD ( $\mathrm{Si}$ ) and biogenic carbonate ( $\mathrm{Sr}$ ) and has been shown to correlate well with \%lithics or total lithics per gram at Sites 609 and U1308 [Hodell et al., 2008; Obrochta et al., 2014]. High Si/Sr values indicate increased abundance of silicate-rich IRD at Site U1308 [Hodell et al., 2008]. Si/Sr is high within both DC-rich layers of Heinrich 1 and is also elevated in the interval leading up 


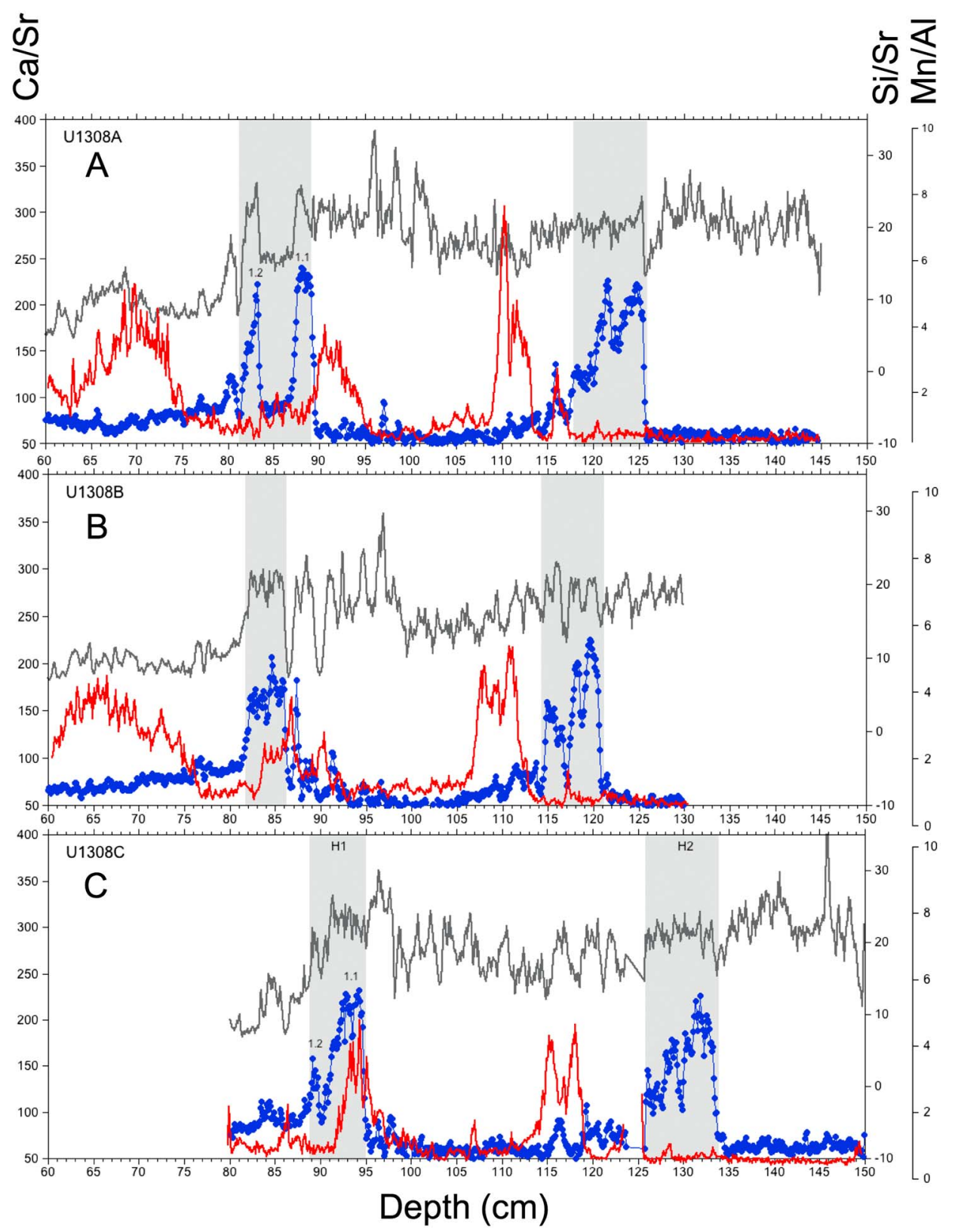

Figure 5. $\mathrm{Ca} / \mathrm{Sr}$ (blue), $\mathrm{Si} / \mathrm{Sr}$ (gray), and $\mathrm{Mn} / \mathrm{Al}$ (red) measured at $1 \mathrm{~mm}$ resolution by core scanning XRF for Holes (a) U1308A, (b) U1308B, and (c) U1308C. Gray shading designates the positions of Heinrich Events $1(\mathrm{H} 1)$ and 2 (H2). Note the differences in the shapes and number of the $\mathrm{Ca} / \mathrm{Sr}$ peaks that is attributed to bioturbation.

to $\mathrm{H} 1$ (Figure 5). There is an increase in $\mathrm{Si} / \mathrm{Sr}$ at $97 \mathrm{~cm}$ in Hole U1308B and $107 \mathrm{~cm}$ in Hole U1308A during HS1, which define the end of the Last Glacial Maximum and beginning of Heinrich Stadial 1.

$\mathrm{Mn} / \mathrm{Al}$ shows three peaks in the top $150 \mathrm{~cm}$ of Site U1308. Two peaks occur between Heinrich Layers 1.1 and 2 with one peak above $\mathrm{H} 2$ and the other near the base of HL1.1 (Figure 5). The third peak occurs at about 65-70 cm above HL1.2.

\subsection{XRD and Point Counting}

Point counting of the $>150 \mu \mathrm{m}$ size fraction in Hole U1308A confirmed the two peaks in DC (Figures 6 and 7), corresponding to the IRD layers that are observed in the CT images and recorded by elemental ratios $(\mathrm{Ca} / \mathrm{Sr})$ measured using the XRF scanner (Figure 5). In Hole U1308A, \% total IRD counts begin to increase between 88 and $88.5 \mathrm{~cm}$. A peak in quartz at $89-89.5 \mathrm{~cm}$ precedes the increase in detrital carbonate at $87-88 \mathrm{~cm}$ (Figure 6) 


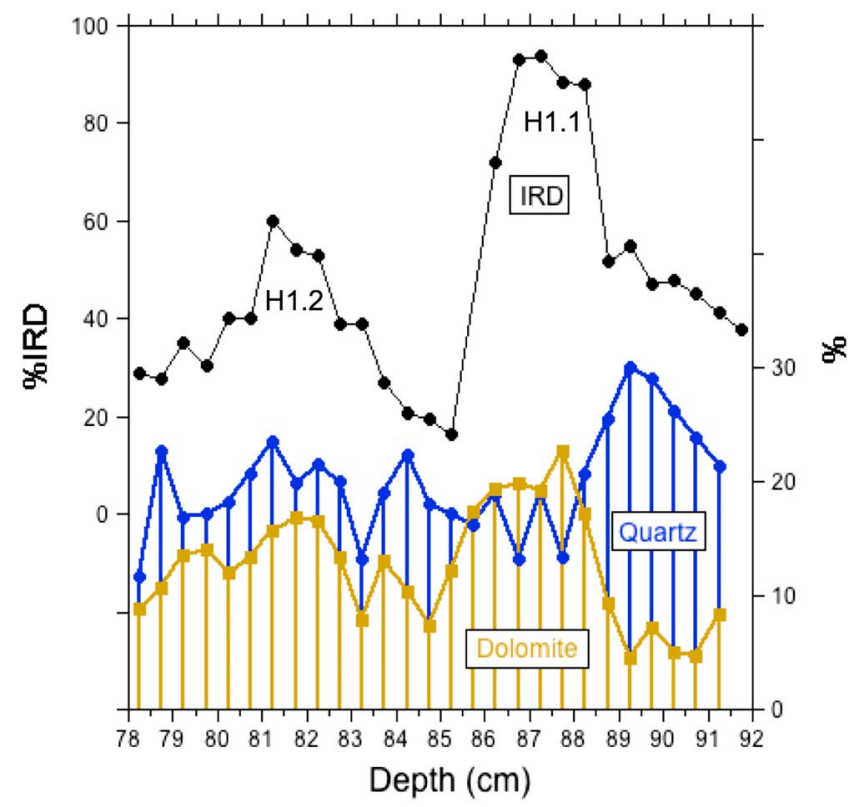

Figure 6. \%IRD in the $>150 \mu \mathrm{m}$ size fraction determined by point counting in Section U1308A-1H-1. \%Dolomite and Quartz were determined by XRD of bulk sediment (Allmann and Hinek, 2007; Madsen and Scarlett, 2008; Cohelo, 2007). The peak in \%quartz at $89-90 \mathrm{~cm}$ is a precursor to Heinrich Events 1.1 and 1.2 that are marked by the peaks in \%IRD and dolomite.

and corresponds with a peak in $\mathrm{Si} / \mathrm{Sr}$ (Figure 5). This early IRD is rich in quartz and may represent a "precursor event" as observed at other sites in the North Atlantic [Grousset et al., 2001].

A double peak also occurs in detrital carbonate and IRD during $\mathrm{H} 1$ at Site 609 [Bond et al., 1992, 1993; Bond and Lotti, 1995], but the sampling resolution at Site 609 was $1 \mathrm{~cm}$ rather than $0.5 \mathrm{~cm}$ used at Site U1308. Nonetheless, two peaks in \% detrital carbonate at 78.5 and $81.5 \mathrm{~cm}$ at Site 609 match the peaks at Site U1308 (see supporting information). The lower IRD layer is the thicker of the two and has a greater concentration of IRD grains and dolomite.

\subsection{Planktonic \\ Foraminiferal Assemblages}

Planktonic foraminifera were counted using standard methods [Vautravers et al., 2004; Vautravers and Shackleton, 2006] following the taxonomy of Kennett and Srinivasan [1983]. Foraminiferal assemblages are nearly $100 \%$ N. pachyderma (sin) below HL1 (Figure 8). The abundance of foraminifera is at a minimum, and \% N. pachyderma (sin) remains near $100 \%$ during HL1.1. Toward the top of HL1.1 at $86.5 \mathrm{~cm}$, the percentage of $N$. pachyderma (sin) declines abruptly as the temperate planktonic foraminifera increase, indicating a rapid warming of surface waters. The sediment between the two IRD peaks of $\mathrm{H} 1 \mathrm{con}$ tains abundant foraminifera consisting of a temperate water assemblage with relatively low percentages of $N$. pachyderma (sin), averaging $30 \%$ of the total assemblage. A small increase in $N$. pachyderma (sin) and

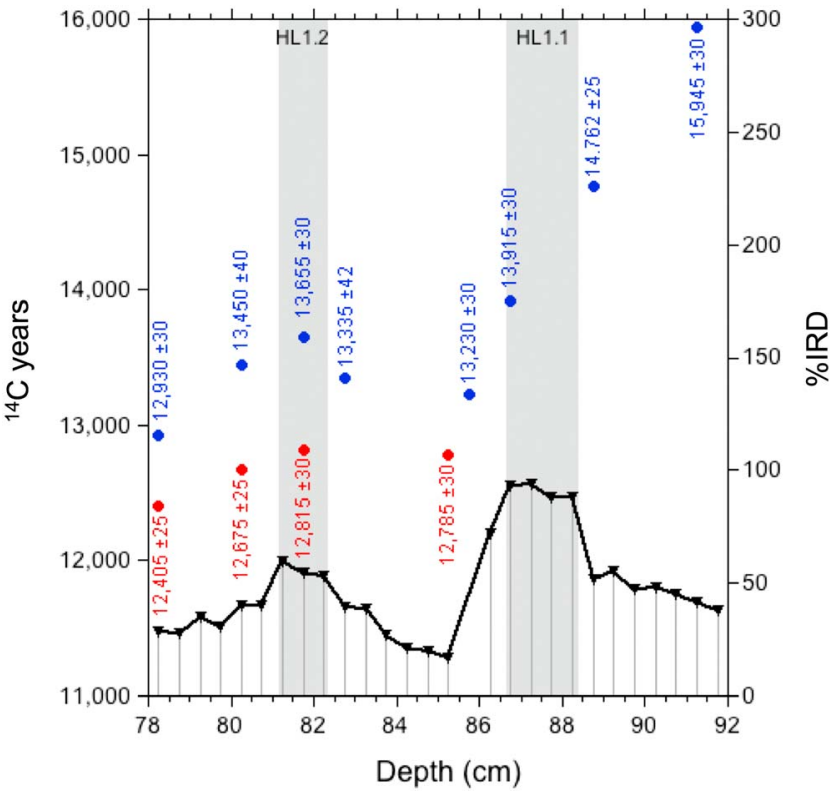

Figure 7. Radiocarbon dates for N. pachyderma (sin) (blue) and G. bulloides (red) in Section U1308A-1H-1 relative to percent ice-rafted detritus. The peaks of HL1.1 and HL1.2 are indicated by gray shading. decrease in foraminiferal abundance is associated with the younger IRD peak $(\mathrm{H} 1.1)$ at $82.0 \mathrm{~cm}$.

\subsection{Stable Isotopes}

The $\delta^{18} \mathrm{O}$ of bulk carbonate was measured using the method of Spötl and Vennemann [2003] and reflects the relative proportion of detrital and biogenic carbonate [Hodell and Curtis, 2008] and shows two distinct lows during HL1, reaching minimum values at 87.5 and $82.5 \mathrm{~cm}$ (Figure 9). Bulk carbonate oxygen isotopes have negative values reaching as low as $-5 \%$. These values are outside the range of biogenic carbonate seen at Site U1308 and are diagnostic of detrital carbonate derived from Hudson Strait [Hodell and Curtis, 2008].

The $\delta^{18} \mathrm{O}$ of $N$. pachyderma (sin) decreases below the base of HL1 beginning $\sim 90 \mathrm{~cm}$ and reaches minimum values at $87.25 \mathrm{~cm}$ in Hole U1308A 


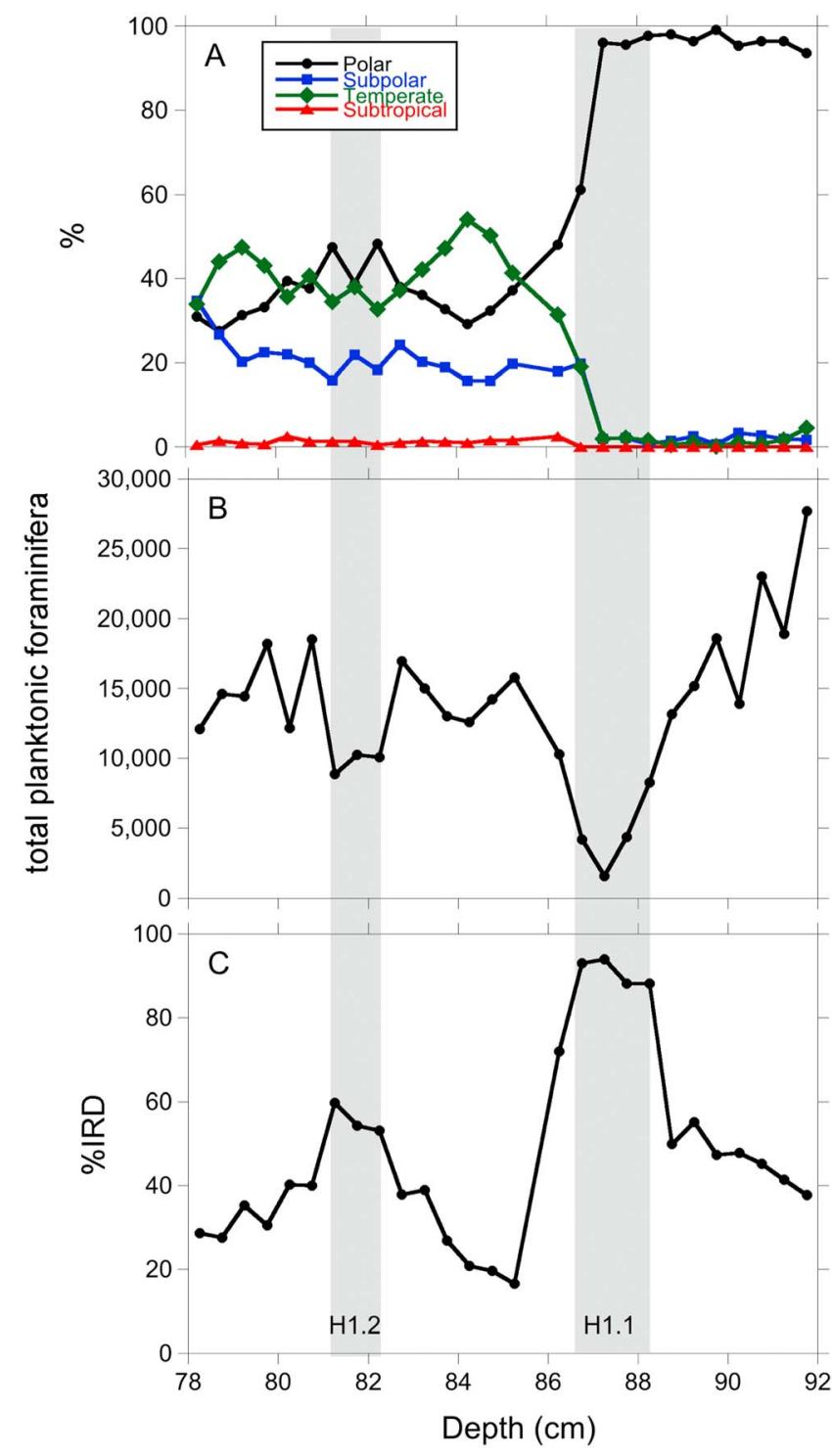

Figure 8. Foraminiferal abundances and \%IRD in Section U1308A-1H-1. (a) \% faunal assemblages species of total foraminifera: polar $=N$. pachyderma $(\mathrm{s}) ;$ subpolar $=T$. quinqueloba + G. glutinata + G. bulloides; temperate/transitional $=G$. inflata $+N$. pachyderma $(\mathrm{d})+G$. scitula; and subtropical $=G$. falconensis $+G$. rubescens $+G$. ruber + G. truncatulinoides $+H$. aequilateralis $+B$. digitata. (b) Total number of whole foraminifer shells of size $>150$. (c) \% IRD in total (= IRD + others) particles $>150 \mu \mathrm{m}$. the distinct double peak in Hole U1308A was primary in origin and not caused by upward dispersal of detrital carbonate from the lower peak by bioturbation. Moreover, the absence of a double peak in Hole U1308B is attributed to bioturbational disturbance that has mixed the two peaks. We therefore focused our efforts on Hole U1308A because it has been less affected by bioturbation than Hole U1308B.

\subsection{Radiocarbon Ages}

Radiocarbon dating was performed in Section U1308A-1H-1 across HL1.1 and HL1.2 to constrain the ages of the two IRD layers. The polar form $N$. pachyderma was measured in eight samples, and G. bulloides was analyzed in four samples. The ages of N. pachyderma are consistently older than G. bulloides at the same stratigraphic level by an average of 650 years (Figure 7 and Table 1). Radiocarbon ages decrease from 92 to $86 \mathrm{~cm}$ and remain relatively constant from 86 to $80 \mathrm{~cm}$ before decreasing again to $78 \mathrm{~cm}$ (Figure 7). 


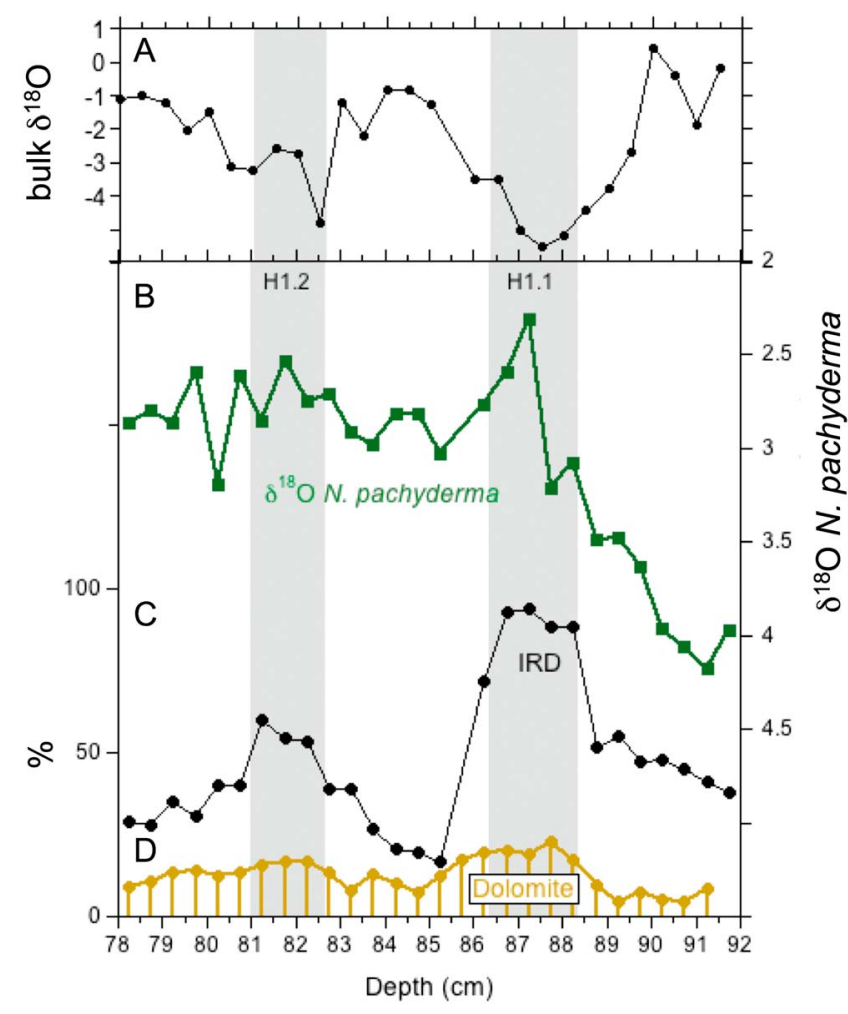

Figure 9. (a) The $\delta^{18} \mathrm{O}$ of bulk carbonate (black) and (b) N. pachyderma (green) compared to (c) \% IRD and (d) \% dolomite in Section U1308A$1 \mathrm{H}-1$.

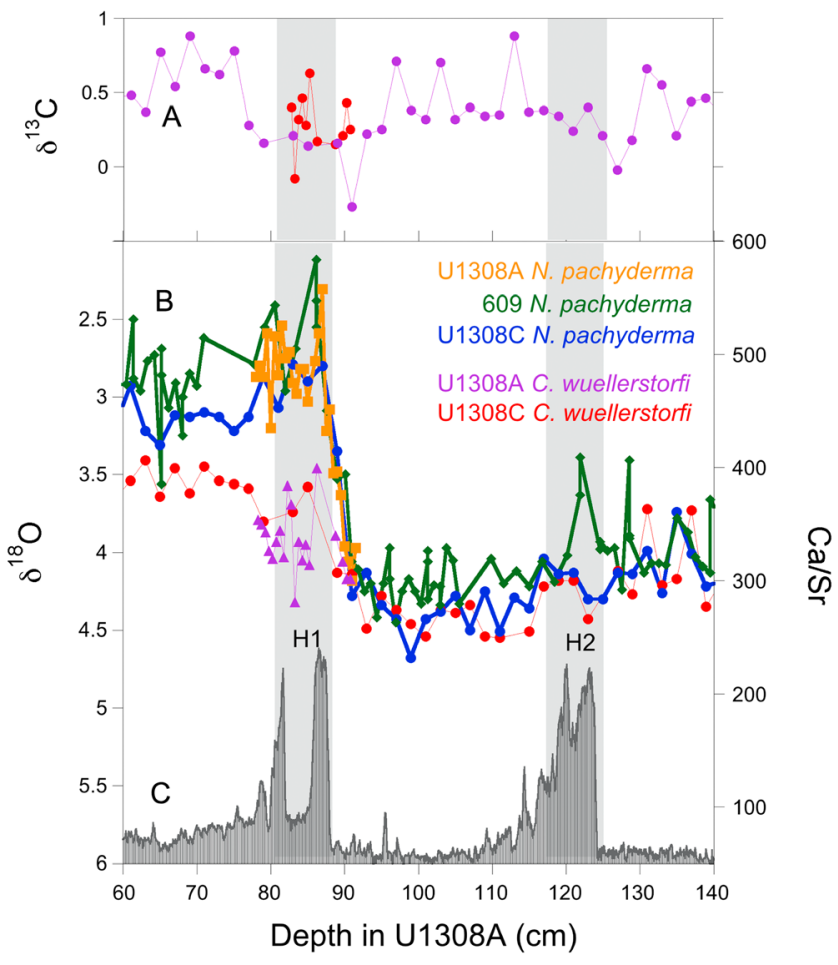

Figure 10. Comparison of (a) benthic carbon and (b) oxygen isotope records of foraminifera at Site U1308 with (c) $\mathrm{Ca} / \mathrm{Sr}$ indicating detrital carbonate-rich IRD events.
The lower DC layer (H1.1) has a sharp base indicating little mixing of material from below the IRD layer (Figures 2 and 3 ). The uncorrected radiocarbon age obtained just below the increase in IRD is $14,762 \pm 45 \Delta^{14} C$ years B.P. at $88.5-89 \mathrm{~cm}$ (Figure 7). The calendar age is dependent upon the assumption made for the reservoir age correction [Reimer et al., 2013]. It is likely that reservoir ages in the glacial North Atlantic were significantly greater than the modern value of 400 years during Heinrich Stadial 1. Stern and Lisiecki [2013] suggested that the reservoir age in the North Atlantic during the early deglacial increased to $>1000{ }^{14} \mathrm{C}$ years between 18.5 and $16.5 \mathrm{kyr}$ B.P. Sarnthein et al. [2015] suggested a reservoir age of 1300 to $1650{ }^{14} \mathrm{C}$ years during HS-1 in the subtropical North Atlantic. Assuming a reservoir age of 1200 years [Stern and Lisiecki, 2013], the calibrated age at $88.5-89 \mathrm{~cm}$ is between 16.2 and $16.5 \mathrm{ka}$ ( 2 sigma), suggesting that the onset of $\mathrm{H} 1.1$ is younger than this age range. This represents a maximum age because bioturbation is suppressed by rapid deposition of the Heinrich layer [Manighetti et al., 1995]. The next dated level at 86.5 to $87 \mathrm{~cm}$ occurs where the $\%$ IRD is high but $N$. pachyderma (s) has decreased to $60 \%$. The radiocarbon age of $13,915 \pm 30{ }^{14} \mathrm{C}$ years gives an age range of 15.6 to 15.2 (2 sigma) assuming a 1000 year reservoir age. This represents a minimum age because Heinrich layers are virtually devoid of foraminifera and downward bioturbation of foraminifera from above is likely (Figure 8b) [Manighetti et al., 1995].

The younger DC layer (H1.2) occurs at $81.5 \mathrm{~cm}$ with a radiocarbon date of $13,355 \pm 42 \quad \Delta^{14} \mathrm{C}$ years B.P. at $82.5-83 \mathrm{~cm}$ just below its base (Figure 7). The calibrated age is between 15.6 and $15.2 \mathrm{ka}$ assuming a reservoir age of 500 years for this time period [Stern and Lisiecki, 2013] (Table 1). HL1.2 has a sharp base but shows evidence of bioturbation at the top of the layer (Figure 11). Radiocarbon ages at $81.75 \mathrm{~cm}$ from the peak of HL1.2 are 


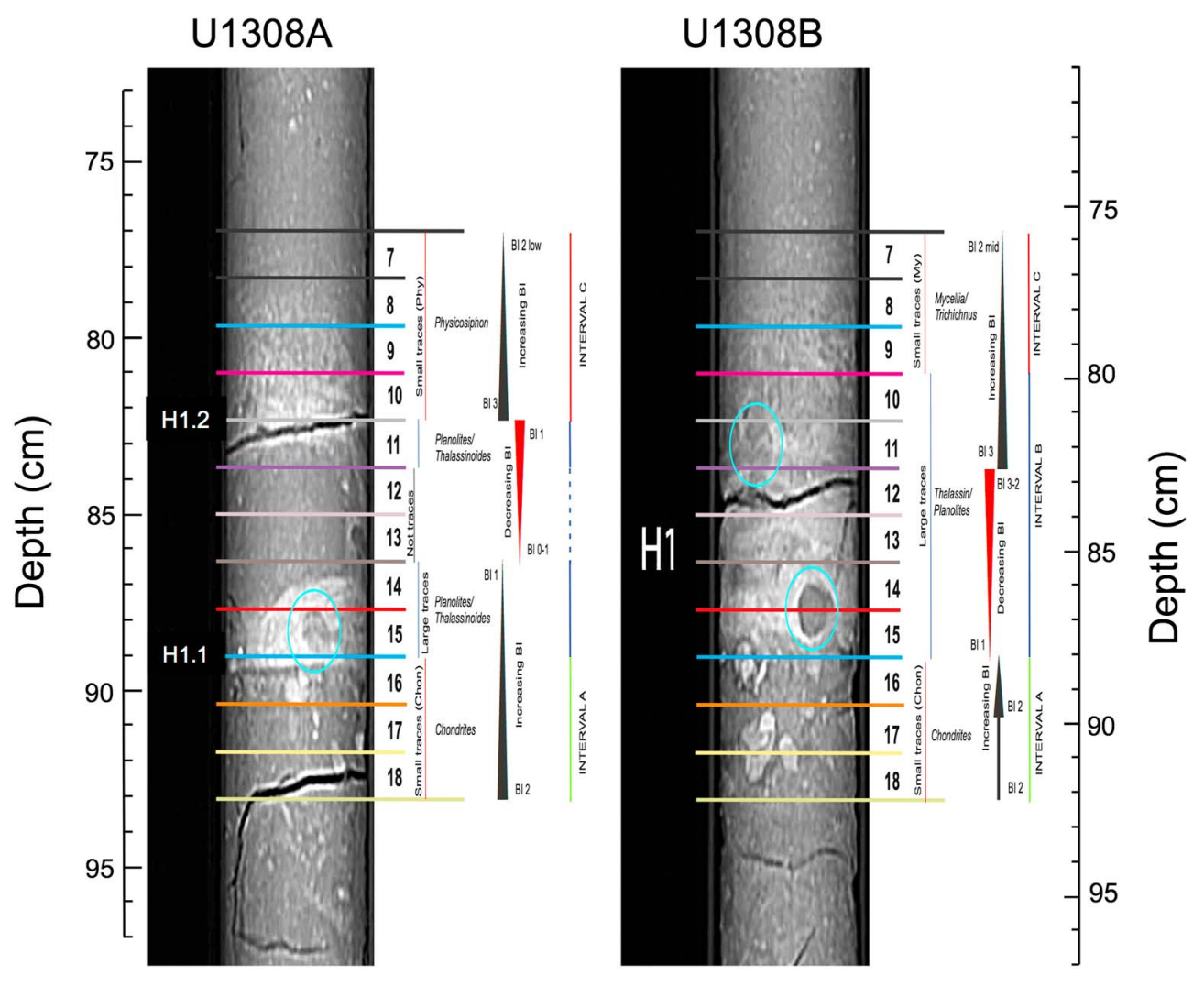

Figure 11. Trace fossil distribution and bioturbation index (BI) in the studied Holes U1308A and U1308B, through the differentiated intervals 18 to 7 . Note the absence of discrete trace fossils in intervals 12 and $13(\mathrm{BI}=0)$ of Hole U1308A and the presence of Thalassinoides and Planolites $(\mathrm{BI}=2-3)$ in the corresponding intervals in Hole U1308B.

$13,655 \pm 30{ }^{14} \mathrm{C}$ years B.P. for N. pachyderma and $12,815 \pm 30{ }^{14} \mathrm{C}$ years B.P. for G. bulloides. The calibrated age range for $N$. pachyderma is 16 to $15.6 \mathrm{ka}$ assuming a 500 year reservoir age and 15.2 to $14.8 \mathrm{ka}$ assuming a 1000 year reservoir age. Radiocarbon dates for $G$. bulloides suggest a younger age (13.9 to $13.7 \mathrm{ka}$ ) for HL1.2 that is within the Bolling-Allerod. N. pachyderma (sin) and G. bulloides may have different reservoir ages given that the environmental tolerances and depth habitats differ between the two species. Alternatively, specimens of G. bulloides may have been mixed down into HL1.2 from the Bolling-Allerod interval above [Manighetti et al., 1995]. The similar ages of both foraminiferal species between 86 and $81 \mathrm{~cm}$ may reflect rapid deposition between HL1.1 and 1.2 or a radiocarbon plateau identified by Sarnthein et al. [2015] between 16.05 and $15.25 \mathrm{ka}$ (Figure 7). The plateau presents difficulty in accurately dating HL1.2.

Table 1. Radiocarbon Dates in Section U1308A-1H-1 ${ }^{\text {a }}$

\begin{tabular}{lccccc} 
Laboratory ID & Hole-Core-Section & Depth $(\mathrm{cm})$ & Species & ${ }^{14}$ C Years (Uncorrected) & \pm \\
\hline 180648 & U1308A-1H-1 & 78.25 & N. pachyderma $(s)$ & 12,930 & 30 \\
180649 & U1308A-1H-1 & 78.25 & G. bulloides & 12,405 & 25 \\
180650 & U1308A-1H-1 & 80.25 & N. pachyderma (s) & 13,450 & 40 \\
180651 & U1308A-1H-1 & 80.25 & G. bulloides & 12,675 & 25 \\
180652 & U1308A-1H-1 & 81.75 & N. pachyderma (s) & 13,655 & 30 \\
180653 & U1308A-1H-1 & 81.75 & G. bulloides & 12,815 & 30 \\
1517.1010 & U1308A-1H-1 & 82.75 & N. pachyderma (s) & 13,355 & 42 \\
180655 & U1308A-1H-1 & 85.25 & G. bulloides & 12,785 & 30 \\
180654 & U1308A-1H-1 & 85.75 & N. pachyderma (s) & 13,230 & 30 \\
180656 & U1308A-1H-1 & 86.75 & N. pachyderma (s) & 13,915 & 30 \\
1517.1010 & U1308A-1H-1 & 88.75 & N. pachyderma (s) & 14,762 & 45 \\
180657 & U1308A-1H-1 & 91.25 & N. pachyderma (s) & 15,945 & 35 \\
\hline
\end{tabular}

${ }^{\mathrm{a}}$ Foraminiferal specimens were cleaned using a modified version of the clay and organic removal cleaning steps of Barker et al. [2003]. 
The radiocarbon dates from Hole U1308A (Table 1) agree well with radiocarbon ages reported by Bond et al. [1992] for Site 609 (see supporting information). At Site 609, the two detrital carbonate peaks occur at 81.5 and $78.5 \mathrm{~cm}$ and the nearest radiocarbon dates are at $84-85 \mathrm{~cm}(14,990 \pm 230)$ and $79-81 \mathrm{~cm}(13,650 \pm 90)$. The radiocarbon dates from Site 609 are in close agreement with the basal dates for $\mathrm{H} 1.1(14,762 \pm 45)$ and H1.2 $(13,355 \pm 42)$ obtained for Hole U1308A.

We produced a radiocarbon age model by combining dates on N. pachyderma from Site U1308 with similar analyses from Site 609 [Bond et al., 1992]. The two sites were correlated precisely to one another using color reflectance [Hodell et al., 2008; Obrochta et al., 2012, 2014]. We used estimates of high-latitude North Atlantic reservoir ages and errors given by Stern and Lisiecki [2013]. The age model was developed with Bacon [Blaauw and Christen, 2011], which uses Bayesian statistics to reconstruct the accumulation history of the profile. Errors in both radiocarbon calibration and estimation of reservoir age are considered. Results include the mean, median, maximum, and minimum ages for each level in the profile (see supporting information). The age model likely overestimates the duration of HL1.1 and 1.2, which were deposited rapidly and likely lasted for only a few hundred years [Francois and Bacon, 1994; Thomson et al., 1995; McManus et al., 1998].

The peak of HL1.1 is estimated at 16.2 ka with a 2 sigma range from 15.5 to $17.1 \mathrm{ka}$. The age of $\sim 16.2 \mathrm{ka}$ for H1.1 agrees well with estimates of $16.13 \pm 0.12$ ka from an ice core drilled into the West Antarctic Ice Sheet (WAIS) [Rhodes et al., 2015], $16.2 \mathrm{ka}$ from the Cariaco Basin off Venezuela [Deplazes et al., 2013], and 16.07 ka from Hulu Cave, China [Treble et al., 2007; Southon et al., 2012; Zhang et al., 2014]. The peak of HL1.2 is estimated at $15.1 \mathrm{ka}$ with a range of 14.3 to $15.9 \mathrm{ka}$. The age model gives an age of $14.7 \mathrm{ka}$ for the base of the Bolling-Allerod warming in the core that matches the date obtained in the Greenland ice core chronology [Svensson et al., 2008].

\section{Discussion}

\subsection{IRD in a Dense Fine-Grained Matrix}

In Hole U1308A, Heinrich Event 1 consists of two discrete density peaks (Figure 4). The coarse IRD grains of $\mathrm{H} 1.1$ and $\mathrm{H} 1.2$ are set within a dense matrix of fine-grained sediment, which is expressed in the CT slices by a cloud of high-density material (Figure 3; also see supporting information). We interpret the fine sediment as glacial flour that is released and dispersed from melting icebergs along with coarser-grained material [Gilbert, 1990]. Glacial flour or rock flour is clay- and silt-sized sediment produced by mechanical grinding of bedrock by glaciers. Glacial-aged icebergs derived from the Laurentide Ice Sheet likely had a greater proportion of fine-grained carbonate than modern Atlantic icebergs, which are derived mainly from the Greenland Ice Sheet, because of efficient grinding of Paleozoic carbonates that underlie Hudson Strait and Hudson Bay [Hiscott and Aksu, 1996; Hesse and Khodabakhsh, 2016; Hesse, 2016].

Although IRD layers are often identified through properties of the coarse-sediment fraction, the sand fraction is usually a relatively small portion of most glacial-derived sediment, which is typically in the silt and clay size range [Andrews, 2000; Andrews and Principato, 2002]. This smaller size fraction is missed in counts of coarsegrained IRD but is a major contributor to glacimarine sedimentation. Glacial flour and especially carbonate can remain in suspension for a long time because of its fine grain size and resistance to flocculation. It can be transported to great distances by currents after release from icebergs. As a result, glacial flour was likely widely dispersed throughout the North Atlantic IRD belt during Heinrich events. The glacial flour increases water turbidity during Heinrich events and, together with low temperatures and increased stratification, suppresses primary productivity that would further hinder this fine material from being incorporated into fecal pellets and sinking [Syvitski, 1989]. As a result, the wide distribution and low $\delta^{18}$ O values of the detrital carbonate from Hudson Strait are particularly useful for detecting Heinrich events within and outside the margins of the North Atlantic IRD belt [Hodell and Curtis, 2008].

Within the poorly sorted IRD layers, the fine-grained glacial flour fills the voids between larger particles resulting in a substantial increase in sediment packing, thereby resulting in high bulk density (Figure 4). The high density may also be a result of partial cementation of Heinrich layers by authigenic dolomite and ankerite [Tamburini et al., 2002]. Heinrich layers were originally described as "cemented marls" in German cruise reports [Heinrich, 1988; Hemming, 2004], and scanning electron microscope photos of Heinrich 
layers at Site U1308 reveal rhombohedral crystals of dolomite, suggesting that at least some of the dolomite is authigenic (see supporting information).

\subsection{Twin Peaks}

Our results from Hole U1308A indicate that Heinrich Layer 1 consisted of two discrete pulses of IRD (Figure 6). The two peaks are not the result of bioturbation or coring disturbance. The twin peaks are also observed in the low-resolution counts of detrital carbonate of Bond et al. [1992] from nearby Site 609, supporting the dual nature of $\mathrm{H} 1$ (see supporting information). Other records also exhibit twin peaks for $\mathrm{H} 1$ across the North Atlantic indicating that it may be a pervasive feature. For example, Heinrich layers typically feature two peaks in coarse-grained detrital carbonate within the Labrador Sea [Rashid et al., 2003]. This pattern has been attributed to the dilution of the middle of a single IRD layer by meltwater input of fine material [Hesse and Khodabakhsh, 1998, 2016; Clarke et al., 1999; Rashid et al., 2003]. However, a record from sediment core GGC31 on the crest of Orphan Knoll (water depth $1796 \mathrm{~m}$ ) also shows the pattern of two peaks in detrital carbonate as observed at Site U1308 [Bond and Lotti, 1995]. This core is relatively shallow, and located on an isolated high, and so is not affected by turbidity currents originating from Hudson Strait and is too far from Hudson Strait to be affected by meltwater plumes derived from the ice sheet terminus [Hesse, 1989; Hesse and Khodabakhsh, 2016]. Similarly, Core EW9302-2JPC (1251 m, 48 $\left.47.70^{\prime} \mathrm{N}, 45^{\circ} 05.09^{\prime} \mathrm{W}\right)$ on the Flemish Cap also shows two distinct peaks during H1 [Marcott et al., 2011]. Site U1302/U1303 at $3600 \mathrm{~m}$ water depth on Orphan Knoll also shows a small secondary peak associated with the main $\mathrm{H} 1$ event (see supporting information).

Sediment core SU90-09, on the southern fringe of the IRD belt, displays two peaks in the proportion of IRD that is detrital carbonate within $\mathrm{H} 1$ [Grousset et al., 2001]. A record from core SU81-18 from the Iberian Margin shows two distinct IRD peaks that coincide with those seen at Site U1308, although only the earlier of the two peaks is rich in detrital carbonate [Bard et al., 2000]. Bard et al. [2000] provided ages of 16.0 $(\mathrm{H} 1 \mathrm{a})$ and $17.5 \mathrm{ka}(\mathrm{H} 1 \mathrm{~b})$ for the two peaks, assuming a reservoir age of 400years for Core SU81-18 on the Iberian Margin. However, Skinner et al. [2014] demonstrated that reservoir ages on the lberian Margin were not a constant 400 years but varied by up to 1800 years during Heinrich Stadial 1. Applying a reservoir correction of $>1000$ years to Core SU81-18 would make $\mathrm{H} 1 \mathrm{~b}$ significantly younger than $17.5 \mathrm{ka}$. We suggest that $\mathrm{H} 1 \mathrm{~b}$ of Bard et al. [2000] is synchronous with $\mathrm{H} 1.1$ at Site U1308. It is the stronger of the two peaks and likely occurred at $16.1 \pm 0.123 \mathrm{ka}$ [Rhodes et al., 2015]. It is uncertain whether H1a of Bard et al. [2000] corresponds to $\mathrm{H} 1.2$ because it does not contain detrital carbonate on the lberian Margin. Two peaks in IRD are similarly recorded on the Laurentian Fan [Gil et al., 2015] and dated at 17.5 and 16 cal kyr B.P. These dates are also based on an age model that used a standard marine reservoir correction of 400 years [Keigwin et al., 2005].

\subsection{Implication of Twin Peaks for Ice Sheet Dynamics}

The two DC-rich IRD layers during $\mathrm{H} 1$ in Hole U1308A suggests that rapid iceberg discharge from the Hudson Strait ice stream may have occurred in two stages or, alternatively, it involved two independent ice streams. Alley and MacAyeal [1994] predicted that all Heinrich events should have a double-peak structure related to the process of freeze on and incorporation of debris into glacial ice. According to their "binge-purge" model [MacAyeal, 1993], ice calved early during the surge is debris laden from the previous freeze-on portion of the binge-purge cycle. When debris-laden basal ice is completely melted off the ice stream, clean icebergs are produced resulting in continued freshwater forcing but a hiatus occurs in IRD deposition, producing a "midpurge hiatus." After freeze on commences but before the purge ends, IRD flux resumes and continues to the end of the purge. Thus, three stages were proposed by Alley and MacAyeal [1994]: (i) the initial IRD output, (ii) a midpurge hiatus devoid of IRD, and (iii) a late purge IRD output. The IRD hiatus occurs because debris-laden basal ice is completely melted from the base of the ice stream during the middle portion of the purge.

Although the two peaks recorded at Hole U1308A appear to support the prediction of Alley and MacAyeal [1994] that IRD flux should reach a maximum twice during each Heinrich event, there are aspects that may not fit the model. According to the model, IRD is absent during the midpurge hiatus but meltwater is still produced from the melting of clean bergs. Planktonic foraminifera assemblages in the intervening sediment between $\mathrm{H} 1.1$ and $\mathrm{H} 1.2$ do not support the presence of cold meltwater at Site U1308 but instead are dominated by subpolar species, especially G. bulloides (Figure 8). The warming between H1.1 and H1.2 at Site 
U1308 does not preclude the possibility of continued iceberg delivery and cooling in the western Atlantic closer to Hudson Strait, but not in the central North Atlantic.

Another consideration is the time difference between the two peaks. Alley and MacAyeal [1994] estimated the total duration of the Heinrich event to be 750 years with the debris hiatus lasting 250 years. The age difference between the base of $\mathrm{H} 1.1$ and $\mathrm{H} 1.2$ is 1400 radiocarbon years, but the absolute age difference between the two peaks depends upon assumptions about the reservoir correction for each date. If the two events occurred at $\sim 16.2$ and $15.1 \mathrm{ka}$, then 1100 years is longer than the predicted duration of 250 years for the midpurge hiatus. The problem is that the 95\% age ranges for HL1.1 (15.5-17.1 ka) and HL1.2 (14.3 to $15.9 \mathrm{ka}$ ) overlap. If $\mathrm{H} 1.2$ is toward the older age of $15.9 \mathrm{ka}$, then the duration of the midpurge hiatus would be consistent with the estimate of Alley and MacAyeal [1994].

Alternatively, the two peaks may represent rapid iceberg delivery from different ice streams, both of which would be underlain by bedrock containing detrital carbonate. The older and main event involved the Hudson Strait Ice Stream. The younger event could be linked to sources from any number of other ice streams draining the eastern margin of the Laurentide Ice Sheet (Figure 1); for example, Rashid et al. [2012] suggested that discharge from the Hudson Strait Ice Stream in $\mathrm{H} 1$ was followed by the Cumberland Sound Ice Stream (Figure 1). A potential problem with this suggestion is that ice sheet basins such as those draining Cumberland Sound are 1 to 2 orders of magnitude smaller that the Hudson Bay-Hudson Strait system, making the delivery of very large numbers of icebergs unlikely. Another possibility is the Laurentian Channell Ice Stream (Figure 1), which has a relatively large drainage-basin area [Dowdeswell et al., 1995]. However, although the St. Lawrence valley contains limestone, we would also expect other lithologies (e.g., Permian-Carboniferous red beds).

\subsection{Warming During HE1}

Several studies have reported warming during or preceding Heinrich events either in the surface or subsurface waters [Jonkers et al., 2010; Marcott et al., 2011; Naafs et al., 2013]. Warming in the subsurface has been observed in several models during Heinrich events and has led to the suggestion that subsurface warming may have been responsible for destabilization of grounded ice shelves followed by surging of ice streams [Hulbe, 1997; Hulbe et al., 2004; Álvarez-Solas et al., 2010; Marcott et al., 2011; Bassis et al., 2017]. A possible problem for models invoking the collapse of extensive floating ice shelves in the delivery of IRD is that strong basal melting, which is common close to ice shelf grounding lines [e.g., Enderlin and Howat, 2013; Rignot et al., 2013], means that icebergs derived from the floating ice shelves themselves may be largely devoid of basal debris [e.g., Alley et al., 2005]. Debris-rich icebergs with significant thicknesses of basal debris more probably come from icebergs sourced from grounded ice streams. Alternatively, ice sheet models can simulate a Heinrich event in response to subsurface warming without the necessity of a floating ice shelf [Bassis et al., 2017].

In Hole U1308A, planktonic foraminifera assemblages suggest that cold conditions occurred prior to and during H1.1. Toward the latter part of H1.1 moderate warming of surface water occurred and continued through the intervening period between $\mathrm{H} 1.1$ and H1.2 (Figure 8). We suggest that the warming during late $\mathrm{H} 1.1$ was related to the breakdown in stratification that occurred once the flux of icebergs was reduced. A slight cooling occurred during $\mathrm{H} 1.2$ followed by a return to warm conditions during the Bølling-Allerød.

The cold conditions during $\mathrm{H} 1.1$ are consistent with model results indicating widespread cooling of North Atlantic SSTs in the IRD belt during Heinrich events in response to freshwater forcing and expanded winter sea ice. Farther south at Site U1313 (41 $\left.{ }^{\circ} \mathrm{N}\right)$, Naafs et al. [2013] found evidence of rapid warming of $2-4^{\circ} \mathrm{C}$ associated with Heinrich events. At Site 976 in the Alboran Sea on the southern Iberian Margin $\left(36^{\circ} 12.3^{\prime} \mathrm{N}\right.$, $\left.4^{\circ} 18.7^{\prime} \mathrm{W}\right), \mathrm{HS} 1$ is punctuated by a sudden brief warming $\left(\sim 4^{\circ} \mathrm{C}\right.$ in less than eight centuries) at $\sim 16 \mathrm{ka}$ (Figure 12) [Martrat et al., 2014]. Measurement of bulk carbonate $\delta^{18} \mathrm{O}$ at Site 976 demonstrates that the warming preceded the decrease in bulk $\delta^{18} \mathrm{O}$, which indicates the arrival of fine-grained detrital carbonate during Heinrich Event 1 (Figure 12). Previous studies have shown that meltwater reached the western Mediterranean during Heinrich events [Sierro et al., 2005], which likely contained fine-grained detrital carbonate from Hudson Strait [Hodell and Curtis, 2008]. Our results indicate a pattern of cooling and sea ice expansion in the high-latitude North Atlantic during H1.1 when warming occurred in the subtropical eastern North Atlantic [Martrat et al., 2014]. These results support oceanic forcing and subsurface warming as a 


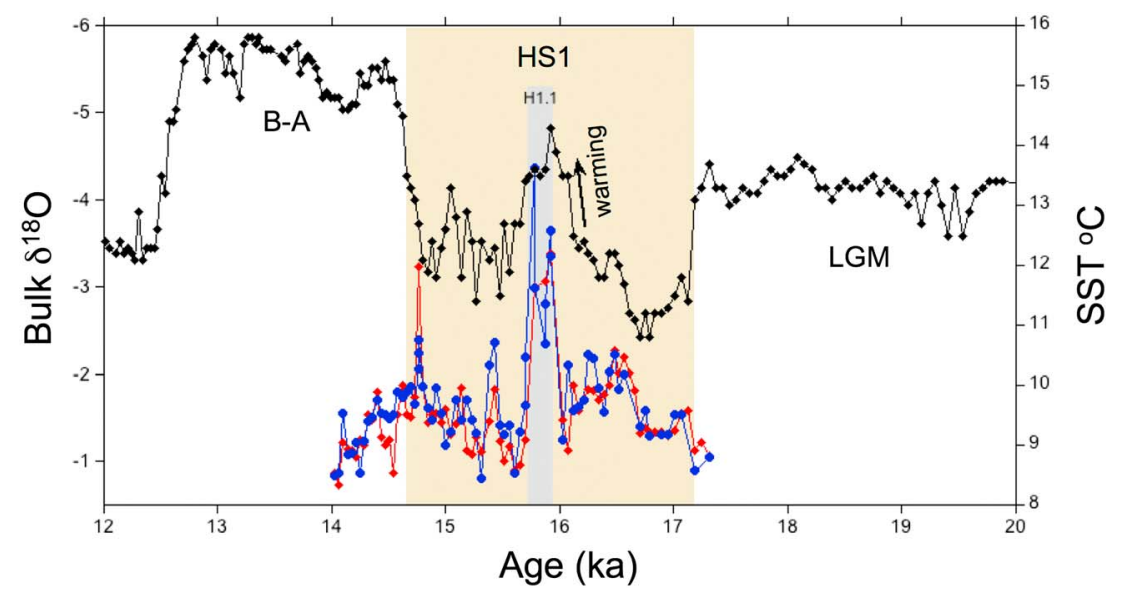

Figure 12. Sea surface temperatures (SSTs) recorded by alkenones [Martrat et al., 2014] relative to the $\delta^{18} \mathrm{O}$ of bulk carbonate at Site 976 in the Alboran Sea (this study), which we interpret as the delivery of fine-grained detrital carbonate to the site during Heinrich Event 1. The yellow shading defines Heinrich Stadial 1 and gray shading HL 1.1. The bulk carbonate $\delta^{18} \mathrm{O}$ was analyzed twice as indicated by the filled circles (blue) and diamonds (red). Note the warming in SST preceded the decrease in bulk carbonate $\delta^{18} \mathrm{O}$ and peaks during $\mathrm{H} 1.1$.

trigger of Heinrich Event 1 [Marcott et al., 2011; Naafs et al., 2013] with [Hulbe, 1997; Hulbe et al., 2004; ÁlvarezSolas et al., 2010, 2011] or without [Bassis et al., 2017] the existence of an ice shelf in the Labrador Sea.

\subsection{Relationship of Heinrich Event 1 and Heinrich Stadial 1?}

It has been proposed that HE1 occurred when the polar North Atlantic was already cold and AMOC weakened [Bond et al., 1992; McManus et al., 1994]. Thus, HE1 was not the trigger for Heinrich Stadial 1 but increased freshwater forcing associated with HE1 may have weakened AMOC further. Figure 13 compares $\mathrm{Ca} / \mathrm{Sr}$ from Site U1308 with Pa/Th from the Bermuda Rise [McManus et al., 1994] and Iberian Margin [Gherardi et al., 2005]. Overturning circulation in the western Atlantic Basin was suppressed throughout HS1 but was particularly weak during the latter half of HS1. The two detrital carbonate peaks at U1308 correspond with the minima in $\mathrm{Pa} / \mathrm{Th}$ between $\sim 16$ and $15 \mathrm{ka}$. The $\mathrm{Pa} / \mathrm{Th}$ record from the Iberian Margin suggests a somewhat different history in that the $\mathrm{Pa} / \mathrm{Th}$ remains low during the first part of HS1 and increases later than the record from the Bermuda Rise [Gherardi et al., 2005, 2009]. On the Iberian Margin, the weakest period of overturning circulation occurs during the period when HL1.1 and HL1.2 were deposited (Figure 13).

Broecker and Putnam [2012] proposed a two-stage subdivision of Heinrich Stadial 1 with a transition at $\sim 16.1 \mathrm{ka}$. During the early stage of HS1 (18 to $16.1 \mathrm{ka}$ ), $\delta^{18} \mathrm{O}$ in Greenland ice cores was less negative indicating warmer temperatures than the latter stages of HS1 (Figure 13). The coldest conditions occurred during the latter half of HS1 (16.1 to $14.7 \mathrm{ka}$ ). The observation that $\mathrm{H} 1$ was not the cause of HS1 raises the question what was responsible for cooling and weakening of overturning circulation in early HS1 prior to the Heinrich event? Several studies show that IRD deposition prior to $\mathrm{H} 1$ in the central and eastern North Atlantic was derived mainly from European and Iceland ice sheets [Grousset et al., 2001; Peck et al., 2006]. Peck et al. [2006] suggested that instability and meltwater forcing by the Northwest European Ice Sheet temporarily weakened AMOC prior to HE1, illustrating that even modest ice sheets can have a disproportionate impact on deep-water circulation if the ice sheet is close to the source of deep-water formation. Toucanne et al. [2010, 2015] found a significant increase in sediment load to the Bay of Biscay at circa 20 ka that reflects the start of European deglaciation with a pronounced peak in Fleuve Manche discharge at 18 ka (Figure 13). The reduction in AMOC during the early part of HS1 may have been driven by earlier melt from the European ice sheet ( 20-16.5 ka) [Peck et al., 2006; Toucanne et al., 2015], whereas the Laurentide played a more significant role during the latter half of HS1 from 16.5 to $14.7 \mathrm{ka}$.

\subsection{Significance of Manganese Peaks}

The base of HL1.1 is sharp and underlain by dark sediment enriched in Mn (Figures 2, 3, and 5). $\mathrm{Mn}^{2+}$ is mobile under reducing conditions and precipitates as $\mathrm{Mn}$ (III, IV) under oxic conditions. It is typically enriched in oxic sediments with a concentration maximum near the surface where reduced $\mathrm{Mn}^{2+}$ migrates from reducing 


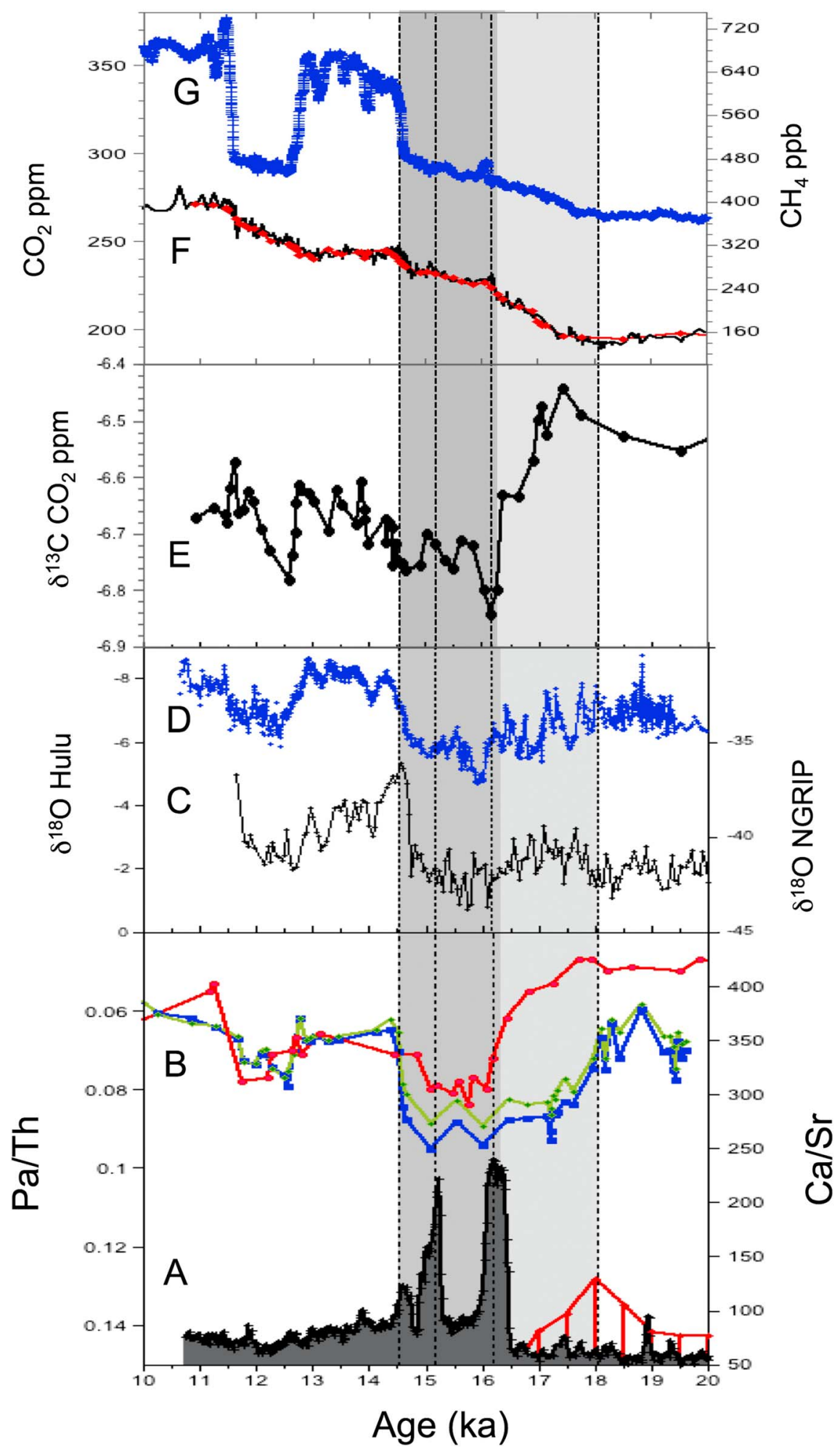

Figure 13. Comparison of (a) Ca/Sr of Site U1308 (filled black) and flux of Fleuve Manche sediment load (red, Toucanne et al., 2010); (b) Pa/Th from the Bermuda Rise (green and blue) [McManus et al., 2004] and Iberian Margin (red) [Gherardi et al., 2005]; (c) the oxygen isotope record of Greenland [North Greenland Project Members, 2004]; (d) the oxygen isotope record of Hulu Cave, China [Wang et al., 2001; Wu et al., 2009, on time scale of Southon et al., 2012]; (e) $\delta^{13} \mathrm{C}$ of atmospheric $\mathrm{CO}_{2}$ from Taylor Glacier [Bauska et al., 2016]; (f) $\mathrm{CO}_{2}$ [Marcott et al., 2014], and (g) $\mathrm{CH}_{4}$ [Rhodes et al., 2015] from the WAIS Divide ice core. The gray shaded areas denote the two-stage subdivision of HS1 at $16.1 \mathrm{ka}$ as suggested by Broecker and Putnam [2012]. 
sediment below and is oxidized at the redox boundary that occurs near the depth of oxygen penetration into the sediments. Three Mn peaks occur in the upper $150 \mathrm{~cm}$ of Site U1308 indicating nonsteady state Mn redox cycling (Figure 5) [Burdige, 1993]. We suggest that the two older peaks represent relict Mn-rich layers that formed at former redox boundaries, whereas the uppermost peak is actively forming today. Dissolution of the older Mn peaks may have been retarded by the deposition of HL1, which impeded upward diffusion of $\mathrm{Mn}^{2+}$ because of its high density and low porosity.

Manganese peaks are often found at glacial-interglacial transitions suggesting a change in redox conditions [Mangini et al., 1990, 1991; Jaccard et al., 2016; Gottschalk et al., 2016]. Because $\mathrm{Mn}^{2+}$ migrates in the sediments, the age of the sediment hosting the $\mathrm{Mn}$ peak provides a maximum age of the redox change [Mangini et al., 2001]. We suggest that the Mn peak associated with HL1.1 formed by a shoaling of the redox boundary in response to lowered oxygen and diminished ventilation of deep water. Similarly, the oldest $\mathrm{Mn}$ peak formed sometime during or after the Last Glacial Maximum. Both peaks are consistent with very old deep-water reservoir ages (between $\sim 2250$ and $~ 3400$ years) in the North Atlantic during the Last Glacial Maximum and HS1 [Skinner et al., 2014] and with lower oxygen concentrations of deep water on the Iberian Margin especially during HS1 [Hoogakker et al., 2015].

In addition to bottom-water oxygenation, several factors can also influence Mn accumulation in marine sediments including changes in organic matter flux and sediment accumulation rate. Certainly, the deposition of the Heinrich layers resulted in large changes in sedimentation rate and we cannot rule out that the enrichment in $\mathrm{Mn}$ is a diagenetic consequence of changing sediment or organic fluxes [Thomson et al., 1996, 1999] rather than changes in deep-water oxygenation.

\subsection{Relationship of Heinrich Event 1 to Deglaciation}

It is uncertain whether HE1 was merely a symptom of the last deglaciation or whether it played a more active role in Termination I. For example, $\mathrm{HE} 1$ may have led to $\mathrm{CO}_{2}$ degassing in the Southern Ocean through a bipolar seesaw mechanism [Sigman et al., 2007; Cheng et al., 2009; Wolff et al., 2009; Denton et al., 2010; Skinner et al., 2014; Marcott et al., 2014; Menviel et al., 2014], thereby hastening deglaciation. In order to evaluate the importance of the observed changes at Site U1308 across the last deglaciation, we compare our record with ice core records of atmospheric $\mathrm{CH}_{4}$ [Rhodes et al., 2015], $\mathrm{CO}_{2}$ [Marcott et al., 2014], and the $\delta^{13} \mathrm{C}$ of atmospheric $\mathrm{CO}_{2}$ [Bauska et al., 2016] (Figure 13).

Rhodes et al. [2015] found a methane spike at $16.1 \mathrm{ka}$ in a WAIS ice core that is not matched by an equivalent increase in Greenland methane. Their interpretation is that $\mathrm{CH}_{4}$ is sourced from the Southern Hemisphere and occurs during Heinrich events when the ITCZ is driven far south. Thus, the methane event provides a constraint on the age of the Heinrich event and duration of its climate impact. The age of $\mathrm{H} 1$ is estimated to be $16.13 \pm 0.12 \mathrm{ka}$, and the duration of the climatic impact is $1515 \pm 38$ years, which agrees within error of age estimate of HL1.1 at Site U1308/609 (Figure 13).

Marcott et al. [2014] reported a high-resolution record of atmospheric $\mathrm{CO}_{2}$ for the last deglaciation and defined two modes of change based on rates of $\mathrm{CO}_{2}$ rise. The first mode is marked by relatively gradual $\mathrm{CO}_{2}$ rise $\left(10 \mathrm{ppm} \mathrm{kyr}^{-1}\right)$ that occurred from 18.1 to $16.1 \mathrm{ka}$ and 13.0 to $11.5 \mathrm{ka}$. The second mode of $\mathrm{CO}_{2}$ change is a series of small, rapid increases during the last termination that occurred at 16.3, 14.8, and $11.7 \mathrm{ka}$ and were synchronous with abrupt increases in $\mathrm{CH}_{4}$ of the order of $\sim 10 \mathrm{ppm}$ in 100-200years [Marcott et al., 2014] (Figure 13). HL1.1 is associated with the small rapid increases in $\mathrm{CO}_{2}$ at $16.3 \mathrm{ka}$. The rapid increases in $\mathrm{CO}_{2}$ and $\mathrm{CH}_{4}$ around 16.3 ka correspond to a negative excursion in $\delta^{13} \mathrm{Cof}_{2} \mathrm{CO}_{2}$ and are associated with H1.1 [Bauska et al., 2016]. The $\delta^{13} \mathrm{C}$ decrease has been interpreted to represent a rapid release of terrestrial organic carbon as a consequence of drying in the Northern Hemisphere related to Heinrich Event 1 when the ITCZ shifted far to the south (Figure 13) [Bauska et al., 2016].

\section{Conclusions}

We have demonstrated that high-resolution XRF core scanning and CT scanning are valuable tools for evaluating internal structure and bioturbation of Heinrich layers. Hole U1308A is minimally affected by bioturbation in the interval between HL1.1 and HL1.2, indicating the deposition of two distinct layers of IRD that are rich in detrital carbonate. Each detrital layer is composed of poorly sorted, coarse-grained clasts 
of IRD embedded in a dense, fine-grained matrix of glacial rock flour that is partially cemented (Figure 3). When sedimentation rates are low and the Heinrich layers are relatively thin, bioturbation can modify or obliterate internal structure of the event, as documented for $\mathrm{H} 1$ in Hole U1308B where only a single mixed peak is observed (Figure 11).

A Bayesian age model of radiocarbon dates provides best estimates for the ages of the two peaks: 16.2 (15.5-17.1) ka for H1.1 and 15.1 (14.3 to 15.9) ka for HL1.2. Uncertainty in reservoir ages and a plateau in radiocarbon ages between 81 and $86 \mathrm{~cm}$ prevent an unambiguous estimate of absolute ages, especially for H1.2 (Figure 7). HL1.1 is clearly the stronger of the two peaks and the estimated age correlates well with climate events recorded in Chinese speleothems [Treble et al., 2007], ice cores [Rhodes et al., 2015], and the sediments of the Cariaco Basin [Deplazes et al., 2013]. HL1.2 is thinner and weaker than HL1.1, and its age is less certain.

The twin peak nature of HL1 is consistent with the model prediction of Alley and MacAyeal [1994] that IRD flux should reach a maximum twice during each Heinrich event. However, planktonic foraminifera indicate a moderate warming during the would-be midpurge hiatus period between HL1.1 and 1.2 (Figure 8), which is not predicted by the model. Alternatively, the two peaks could represent discharge of two independent ice streams that are underlain by limestone, although this appears less likely.

Heinrich Stadial 1 marks the start of the last deglaciation and is characterized by cooling in the North Atlantic at the same time as Antarctic temperatures warmed, $\mathrm{CO}_{2}$ and $\mathrm{CH}_{4}$ began to increase, $\delta^{13} \mathrm{C}_{\text {of }} \mathrm{CO}_{2}$ decreased, and the radiocarbon age of the atmosphere became older [Broecker and Barker, 2007; Marcott et al., 2014; Rhodes et al., 2015; Bauska et al., 2016]. Our results suggest a complex history for Heinrich Stadial 1 and support a twofold subdivision suggested by Broecker and Putnam [2012] with a transition at 16.1-16.2 ka. Heinrich Event 1.1 occurred midway through Heinrich Stadial 1 when the polar North Atlantic was already cold and overturning circulation weakened. Warming ensued in the subtropical North Atlantic prior to and during H1.1, whereas it was delayed at Site U1308 until the end of H1.1 when the production of icebergs waned and surface water stratification declined. HS1 may have been influenced by melting of European ice sheets during the early phase ( 19 to $16.1 \mathrm{ka}$ ), whereas Laurentide Ice Sheet dynamics dominated during the latter half of HS1 (16.2 to $14.7 \mathrm{ka})$.

Acknowledgments

We thank Nick Evans and Giulio Lampronti for XRD analysis and Vera Lukies (MARUM) for assistance with XRF core scanning. David Naafs and an anonymous referee substantially improved the manuscript through their detailed reviews. This research used data acquired at the XRF Core Scanner Lab at the MARUM-Center for Marine Environmental Sciences, University of Bremen, Germany. This research used samples provided by the International Ocean Discovery Program (IODP). Funding for this research was provided by the UK Natural Environmental Research Council (NERC) to Hodell. The NERC Radiocarbon Facility supported two radiocarbon dates, and Wally Broecker generously supported the remainder with funding from the Comer Family Foundation. Research by Rodríguez-Tovar and Dorador was financed by Project CGL2015-66835-P. B.M. acknowledges support from the CSIC-Ramón y Cajal postdoctoral programme RYC-2013-14073. J.F.E. would like to acknowledge funding under ERC Advanced grant 320750Nanopaleomagnetism. All data are archived with Pangaea (https://www. pangaea.de/) and NOAA (https://www. ncdc.noaa.gov/data-access/paleoclimatology-data) information systems.

\section{References}

Alley, R. B., and D. R. MacAyeal (1994), Ice-rafted debris associated with binge/purge oscillations of the Laurentide Ice Sheet, Paleoceanography, 9(4), 503-512, doi:10.1029/94PA01008.

Alley, R. B., J. T. Andrews, D. C. Barber, and P. U. Clark (2005), Comment on "Catastrophic ice shelf breakup as the source of Heinrich event icebergs" by C. L. Hulbe et al., Paleoceanography, 20, PA1009, doi:10.1029/2004PA001086.

Allmann, R., and R. Hinek (2007), The introduction of structure types into the Inorganic Crystal Structure Database ICSD, Acta Cryst, A63, 412-417.

Álvarez-Solas, J., S. Charbit, C. Ritz, D. Paillard, G. Ramstein, and C. Dumas (2010), Links between ocean temperature and iceberg discharge during Heinrich events, Nat. Geosci., 3, 122-126.

Álvarez-Solas, J., M. Montoya, C. Ritz, G. Ramstein, S. Charbit, C. Dumas, K. Nisancioglu, T. Dokken, and A. Ganopolski (2011), Heinrich event 1: An example of dynamical ice-sheet reaction to oceanic changes, Clim. Past, 7, 1297-1306, doi:10.5194/cp-7-1297-2011.

Andrews, J. T. (2000), Icebergs and iceberg rafted detritus (IRD) in the North Atlantic: Facts and assumptions, Oceanography, 13(3), 100-108.

Andrews, J. T., and K. Tedesco (1992), Detrital carbonate-rich sediments, northwestern Labrador Sea: Implications for ice-sheet dynamics and iceberg rafting (Heinrich) events in the North Atlantic, Geology, 20, 1087-1090.

Andrews, J. T., and S. M. Principato (2002), Grain-size characteristics and provenance of ice-proximal glacial marine sediments (or why do we do grain-size analyses anyway?), in Glacier Influenced Sedimentation at High Latitude Continental Margins, vol. 203, edited by J. A. Dowdeswell and C. O'Cofaigh, pp. 305-324, Geol. Soc. London Spec. Publ., Bath, U. K.

Bard, E., F. Rostek, J.-L. Turon, and S. Gendreau (2000), Hydrological impact of Heinrich events in the subtropical Northeast Atlantic, Science, $289,1321-1324$.

Barker, S., M. Greaves, and H. Elderfield (2003), A study of cleaning procedures used for foraminiferal Mg/Ca paleothermometry, Geochem. Geophys. Geosyst., 4(9), 8407, doi:10.1029/2003GC000559.

Barker, S., P. Diz, M. J. Vautravers, J. Pike, G. Knorr, I. R. Hall, and W. S. Broecker (2009), Interhemispheric Atlantic seesaw response during the last deglaciation, Nature, 457, 1097-1103.

Bassis, J. N., S. V. Petersen, and L. Mac Cathles (2017), Heinrich events triggered by ocean forcing and modulated by isostatic adjustment, Nature, 542, 332-334.

Bauska, T. K., D. Baggenstos, E. J. Brook, A. C. Mix, S. A. Marcott, V. V. Petrenko, H. Schaefer, J. P. Severinghaus, and J. E. Lee (2016), Carbon isotopes characterize rapid changes in atmospheric carbon dioxide during the last deglaciation, Proc. Nat. Acad. Sci. U.S.A., 113(13), 3465-3470.

Blaauw, M., and J. A. Christen (2011), Flexible paleoclimate age-depth models using an autoregressive gamma process, Bayesian Anal., 6 , 457-474.

Bond, G. C., and R. Lotti (1995), Iceberg discharges into the North Atlantic on millennial time scales during the last glaciation, Science, 267 1005-1010, doi:10.1126/science.267.5200.1005. 
Bond, G. C., W. Showers, M. Elliot, M. Evans, R. Lotti, I. Hajdas, G. Bonani, and S. Johnson (1999), The North Atlantic's 1-2 kyr climate rhythm: Relation to Heinrich events, Dansgaard/Oeschger cycles and the Little Ice Age, in Mechanisms of Global Climate Change at Millennial Time Scales, Geophys. Monogr. Ser., vol. 112, edited by P. U. Clark, R. S. Webb, and L. D. Keigwin, pp. 35-58, AGU, Washington, D. C.

Bond, G., et al. (1992), Evidence for massive discharges of icebergs into the North Atlantic Ocean during the last glacial period, Nature, 360 , 245-249, doi:10.1038/360245a0.

Bond, G., W. Broecker, S. Johnsen, J. McManus, L. Labeyrie, J. Jouzel, and G. Bonani (1993), Correlations between climate records from North Atlantic sediments and Greenland ice, Nature, 365, 143-147.

Broecker, W., and A. E. Putnam (2012), How did the hydrologic cycle respond to the two-phase mystery interval?, Quat. Sci. Rev., 57, $17-25$.

Broecker, W. S., G. Bond, M. Klas, E. Clark, and J. McManus (1992), Origin of the northern Atlantic's Heinrich events, Clim. Dyn., 6, 265-273, doi:10.1007/BF00193540.

Broecker, W. S., and S. Barker (2007), A 190\%o drop in atmosphere's $\Delta^{14} \mathrm{C}$ during the "Mystery Interval" (17.5 to $\left.14.5 \mathrm{kyr}\right)$, Earth Planet. Sci. Lett., 256(1), 90-99, doi:10.1016/j.epsl.2007.01.015.

Burdige, D. J. (1993), The biogeochemistry of manganese and iron reduction in marine sediments, Earth Sci. Rev., 35, $249-284$.

Cheng, H., R. L. Edwards, W. S. Broecker, G. H. Denton, X. Kong, Y. Wang, R. Zhang, and X. Wang (2009), Ice age terminations, Science, 326(5950), 248-252.

Clarke, G. K. C., S. J. Marshall, C. Hillaire-Marcel, G. Bilodeau, and C. Veiga-Pires (1999), A glaciological perspective on Heinrich events, in Mechanisms of Global Climate Change at Millennial Time Scales, vol. 112, edited by P. U. Clark, R. S. Webb, and L. D. Keigwin, pp. 243-262, AGU, Washington, D. C.

Cohelo, A. (2007), TOPAS-Academic, Coelho Software, Brisbane, Australia.

Denton, G. H. and T. J. Hughes (Eds.) (1981), The Last Great Ice Sheets, 484 pp., John Wiley, New York.

Denton, G. H., R. F. Anderson, J. R. Toggweiler, L. Edwards, J. M. Schaefer, and A. E. Putnam (2010), The last glacial termination, Science, 328, 1652-1656.

Deplazes, G., et al. (2013), Links between tropical rainfall and North Atlantic climate during the last glacial period, Nat. Geosci., 6, $213-217$.

Dorador, J., and F. J. Rodríguez-Tovar (2014), A novel application of digital image treatment by quantitative pixel analysis to trace fossil research in marine cores, Palaios, 29, 533-538.

Dorador, J., F. J. Rodríguez-Tovar, and IODP Expedition 339 Scientists (2014a), Digital image treatment applied to ichnological analysis of marine core sediments, Facies, 60, 39-44.

Dorador, J., F. J. Rodríguez-Tovar, and IODP Expedition 339 Scientists (2014b), Quantitative estimation of bioturbation based on digital image analysis, Mar. Geol., 349, 55-60.

Doube, M., M. M. Kłosowski, I. Arganda-Carreras, F. P. Cordelieres, R. P. Dougherty, J. S. Jackson, B. Schmid, J. R. Hutchinson, and S. J. Shefelbine (2010), BoneJ: Free and extensible bone image analysis in ImageJ, Bone, 47(6), 1076-1079.

Dowdeswell, J. A., M. A. Maslin, J. T. Andrews, and I. N. McCave (1995), Iceberg production, debris rafting, and the extent and thickness of Heinrich layers (H-1, H-2) in North Atlantic sediments, Geology, 23(4), 301-304.

Enderlin, E. M., and I. M. Howat (2013), Submarine melt rate estimates for floating termini of Greenland outlet glaciers (2000-2010), J. Glaciol., $59,67-75$.

Expedition 303 Scientists (2006), Site U1308, in Proc. IODP, 303/306, edited by J. E. T. Channell et al., Integrated Ocean Drilling Program Management International, Inc., College Station, Tex., doi:10.2204/iodp.proc.303306.108.2006.

Francois, R., and M. P. Bacon (1994), Heinrich events in the North Atlantic: Radiochemical evidence, Deep Sea Res., Part I, 41, 315-334.

Gherardi, J.-M., L. Labeyrie, J. F. McManus, R. Francois, L. C. Skinner, and E. Cortijo (2005), Evidence from the northeastern Atlantic basin for variability in the rate of the meridional overturning circulation through the last deglaciation, Earth Planet. Sci. Lett., 240, 710-723.

Gherardi, J.-M., L. Labeyrie, S. Nave, R. Francois, J. F. McManus, and E. Cortijo (2009), Glacial-interglacial circulation changes inferred from ${ }^{231} \mathrm{~Pa} /{ }^{230}$ Th sedimentary record in the North Atlantic region, Paleoceanography, 24, PA2204, doi:10.1029/2008PA001696.

Gil, I. M., L. D. Keigwin, and F. Abrantes (2015), The deglaciation over Laurentian Fan: History of diatoms, IRD, ice and fresh water, Quat. Sci. Rev., 129, 57-67.

Gilbert, R. (1990), Rafting in glacimarine environments, in Glacimarine Processes and Sedimentation, vol. 53, edited by J. A. Dowdeswell and J. D. Scourse, pp. 105-120, Geol. Soc. London Spec. Publ., Bath, U. K.

Gottschalk, J., L. C. Skinner, J. Lippold, H. Vogel, N. Frank, S. L. Jaccard, and C. Waelbroeck (2016), Biological and physical controls in the Southern Ocean on past millennial-scale atmospheric $\mathrm{CO}_{2}$ changes, Nat. Commun., 7, 11,539, doi:10.1038/ncomms 11539 .

Grousset, F. E., E. Cortijo, S. Huon, L. Herve, T. Richter, D. Burdloff, J. Duprat, and O. Weber (2001), Zooming in on Heinrich layers, Paleoceanography, 16(3), 420-259, doi:10.1029/2000PA000559.

Grützner, J., and S. M. Higgins (2010), Threshold behavior of millennial scale variability in deep water hydrography inferred from a $1.1 \mathrm{Ma}$ long record of sediment provenance at the southern Gardar Drift, Paleoceanography, 25, PA4204, doi:10.1029/2009PA001873.

Heinrich, H. (1988), Origin and consequences of cyclic ice rafting in the northeast Atlantic Ocean during the past 130,000 years, Quat. Res., 29, 142-152, doi:10.1016/0033-5894(88)90057-9.

Hemming, S. R. (2004), Heinrich events: Massive late Pleistocene detritus layers of the North Atlantic and their global climate imprint, Rev. Geophys., 42, RG1005, doi:10.1029/2003RG000128.

Hesse, R. (2016), Ice-proximal Labrador Sea Heinrich layers: A sedimentological approach, Can. J. Earth Sci., 53, 71-100.

Hesse, R. (1989), Drainage systems associated with mid-ocean channels and submarine yazoos: Alternative to submarine fan depositional systems, Geology, 17, 1148-1151.

Hesse, R., and S. Khodabakhsh (1998), Depositional facies of late Pleistocene Heinrich events in the Labrador Sea, Geology, 26, $103-106$. Hesse, R., and S. Khodabakhsh (2016), Anatomy of Labrador Sea Heinrich layers, Mar. Geol., 380, 44-66, doi:10.1016/j.margeo.2016.05.019.

Hesse, R., H. Rashid, and S. Khodabakhsh (2004), Fine-grained sediment lofting from meltwater-generated turbidity currents during Heinrich events, Geology, 32, 449-452.

Hiscott, R. N., A. E. Aksu (1996), Quaternary sedimentary processes and budgets in Orphan Basin, Southwestern Labrador Sea, Quat. Res., 4(2), $160-175$.

Hodell, D. A., and J. H. Curtis (2008), Oxygen and carbon isotopes of detrital carbonate in North Atlantic Heinrich events, Mar. Geol., 256, 30-35, doi:10.1016/j.margeo.2008.09.010.

Hodell, D. A., J. E. T. Channell, J. H. Curtis, O. E. Romero, and U. Röhl (2008), Onset of "Hudson Strait" Heinrich events in the eastern North Atlantic at the end of the middle Pleistocene transition ( 640 ka)?, Paleoceanography, 23, PA4218, doi:10.1029/2008PA001591.

Hoogakker, B. A. A., H. Elderfield, G. Schmiedl, N. McCave, and R. E. M. Rickaby (2015), Glacial-interglacial changes in bottom-water oxygen content on the Portuguese margin, Nat. Geosci., 8, 40-43. 
Hulbe, C. L. (1997), An ice shelf mechanism for Heinrich layer production, Paleoceanography, 1(5), 711-717, doi:10.1029/97PA02014.

Hulbe, C. L., D. R. MacAyeal, G. H. Denton, J. Kleman, and T. V. Lowell (2004), Catastrophic ice shelf breakup as the source of Heinrich event icebergs, Paleoceanography, 19, PA1004, doi:10.1029/2003PA000890.

Jaccard, S. L., E. D. Galbraith, A. Martinez-Garcia, and R. R. Anderson (2016), Covariation of deep Southern Ocean oxygenation and atmospheric $\mathrm{CO}_{2}$ through the last ice age, Nature, 530, 207-210.

Jonkers, L., M. Moros, M. A. Prins, T. Dokken, C. Andersson Dahl, N. Dijkstra, K. Perner, and G.-J. A. Brummer (2010), A reconstruction of sea surface warming in the northern North Atlantic during MIS 3 ice-rafting events, Quat. Sci. Rev., 29(15), 1791-1800.

Keigwin, L. D., J. Sachs, Y. Rosenthal, and E. A. Boyle (2005), The 8200 year B.P. event in the slope water system, western subpolar North Atlantic, Paleoceanography, 20, PA2003, doi:10.1029/2004PA001074.

Kennett, J. P., and M. S. Srinivasan (1983), Neogene Planktonic Foraminifera: A Phylogenetic Atlas, Hutchinson Ross, Stroudsburg, Pa.

MacAyeal, D. R. (1993), Binge/purge oscillations of the Laurentide Ice Sheet as a cause of the North Atlantic's Heinrich events, Paleoceanography, 8, 775-784, doi:10.1029/93PA02200.

Madsen, I. C., and N. V. Y. Scarlett (2008), Quantitative phase analysis, in Powder Diffraction: Theory and Practice, edited by R. E. Dinnabier, Royal Society of Chemistry, Cambridge.

Mangini, A., A. Eisenhauer, and P. Walter (1990), Response of manganese in the ocean to the climatic cycles in the Quaternary, Paleoceanography, 5(5), 811-821, doi:10.1029/PA005i005p00811.

Mangini, A., A. Eisenhauer, and P. Walter (1991), A spike of $\mathrm{CO}_{2}$ in the atmosphere at glacial-interglacial boundaries induced by raid deposition of manganese in the oceans, Tellus, Ser. $B, 43,97-105$.

Mangini, A., M. Jung, and S. Laukenmann (2001), What do we learn from peaks of uranium and of manganese in deep sea sediments?, Mar Geol., 177, 63-78.

Manighetti, B., I. N. McCave, M. Maslin, and N. J. Shackleton (1995), Chronology for climate change: Developing age models for the Biogeochemical Ocean Flux Study cores, Paleoceanography, 10(3), 513-525, doi:10.1029/94PA03062.

Marcott, S. A., et al. (2011), Ice-shelf collapse from subsurface warming as a trigger for Heinrich events, Proc. Nat. Acad. Sci. U.S.A., 108(33), $13,415-13,419$.

Marcott, S. A., et al. (2014), Centennial-scale changes in the global carbon cycle during the last deglaciation, Nature, 514, 616-619.

Martrat, B., P. Jimenez-Amat, R. Zahn, and J. O. Grimalt (2014), Similarities and dissimilarities between the last two deglaciations and interglaciations in the North Atlantic region, Quat. Sci. Rev., 99, 122-134.

McManus, J. F., G. C. Bond, W. S. Broecker, S. Johnsen, L. Labeyrie, and S. Higgins (1994), High-resolution climate records from the North Atlantic during the last interglacial, Nature, 371, 326-329, doi:10.1038/371326a0.

McManus, J. F., R. F. Anderson, W. S. Broecker, M. Q. Fleisher, and S. M. Higgins (1998), Radiometrically determined sedimentary fluxes in the sub-polar North Atlantic during the last 140,000 years, Earth Planet. Sci. Lett., 155, 29-43.

McManus, J. F., R. Francois, J.-M. Gherardi, L. D. Keigwin, and S. Brown-Leger (2004), Collapse and rapid resumption of Atlantic meridional circulation linked to deglacial climate changes, Nature, 428(6958), 834-837.

Menviel, L., M. H. England, K. J. Meissner, A. Mouchet, and J. Yu (2014), Atlantic-Pacific seesaw and its role in outgassing $\mathrm{CO}_{2}$ during $\mathrm{Heinrich}$ events, Paleoceanography, 29, 58-70, doi:10.1002/2013PA002542.

Naafs, B. D. A., J. Hefter, J. Grützner, and R. Stein (2013), Warming of surface waters in the midlatitude North Atlantic during Heinrich events, Paleoceanography, 28, 153-163, doi:10.1029/2012PA002354.

North Greenland Project Members (2014), High-resolution record of Northern Hemisphere climate extending into the last interglacial period, Nature, 431, 147-151.

Obrochta, S. P., H. Miyahara, Y. Yokoyama, and T. J. Crowley (2012), A re-examination of evidence for the North Atlantic "1500-year cycle" at Site 609, Quat. Sci. Rev., 55, 22-33.

Obrochta, S. P., T. J. Crowley, J. E. T. Channell, D. A. Hodell, P. A. Baker, A. Seki, and Y. Yokoyama (2014), Climate variability and ice-sheet dynamics during the last three glaciations, Earth Planet. Sci. Lett., 406, 198-212.

Peck, V. L., I. R. Hall, R. Zahn, H. Elderfield, F. Grousset, S. R. Hemming, and J. D. Scourse (2006), High resolution evidence for linkages between NW European ice sheet instability and Atlantic Meridional Overturning Circulation, Earth Planet. Sci. Lett., 243, 476-488.

Rashid, H., R. Hesse, and D. J. W. Piper (2003), Origin of unusually thick ice-proximal Heinrich layers H-1 to H-3 in the northwest Labrador Sea, Earth Planet. Sci. Lett., 208, 319-336.

Rashid, H., F. Saint-Ange, D. C. Barber, M. E. Smith, and N. Devalia (2012), Fine scale sediment structure and geochemical signature between eastern and western North Atlantic during Heinrich events 1 and 2, Quat. Sci. Rev., 46, 136-150.

Reimer, P. J., et al. (2013), IntCal13 and Marine13 radiocarbon age calibration curves 0-50,000 years cal BP, Radiocarbon, 50(4), 1869-1887.

Rhodes, R. H., E. J. Brook, J. C. H. Chiang, T. Blunier, O. Maselli, J. R. McConnell, D. Romanini, and J. P. Severinghaus (2015), Enhanced tropical methane production in response to iceberg discharge in the North Atlantic, Science, 348(6238), 1016-1019.

Rignot, E., S. Jacobs, J. Mouginot, and B. Scheuchl (2013), Ice-shelf melting around Antarctica, Science, 341, $266-270$.

Rodríguez-Tovar, F. J., and J. Dorador (2015), Ichnofabric characterization in cores: A method of digital image treatment, Ann. Soc. Geol. Pol., 85, 465-471.

Röhl, U., and L. J. Abrams (2000), High-resolution, downhole and non-destructive core measurements from Sites 999 and 1001 in the Caribbean Sea: Application to the late Paleocene thermal maximum, in Proceedings of the Ocean Drilling Program, vol. 165, edited by R. M. Leckie et al., pp. 191-203, Sci Results, College Station, Tex.

Ruddiman, W. F. (1977), Late Quaternary deposition of ice-rafted sand in the subpolar North Atlantic (lat $40^{\circ}$ to $65^{\circ} \mathrm{N}$ ), Geol. Soc. Am. Bull., 88 , 1813-1827, doi:10.1130/0016-7606(1977)88<1813:LQDOIS > 2.0.CO;2

Sanchez Goñi, M. F., and S. P. Harrison (2010), Millennial-scale climate variability and vegetation changes during the last Glacial: Concepts and terminology, Quat. Sci. Rev., 29, 2823-2827.

Sarnthein, M., S. Balmer, P. M. Grootes, and M. Mudelsee (2015), Planktic and bnethic 14C reservoir ages for three ocean basins, calibrated by a suite of 14C plateaus in the glacial-to-deglacial Suigetsu atmospheric 14C record, Radiocarbon, 57(1), 129-151.

Schindelin, J., I. Arganda-Carreras, and E. Frise (2012), Fiji: An open-source platform for biological-image analysis, Nat. Methods, 9(7), 676-682.

Sierro, F. J., D. A. Hodell, J. Curtis, J. A. Flores, I. Reguera, E. Colmenero-Hidalgo, M. A. Barcena, J. Grimalt, and M. Canals (2005), Impact of iceberg melting during Heinrich events on Mediterranean thermohaline circulation, Paleoceanography, 20, PA2019, doi:10.1029/ 2004PA001051.

Sigman, D., A. M. de Boer, and G. H. Haug (2007), Antarctic stratification, atmospheric water vapor, and Heinrich events: A hypothesis for Late Pleistocene deglaciations (geophysical monograph), in Ocean Circulation: Mechanisms and Impacts Past and Future Changes of Meridional Overturning, edited by A. Schmittner, J. C. H. Chiang, and S. Hemmings, pp. 335-349, AGU, Washington, D. C. 
Skinner, L. C., C. Waelbroeck, A. E. Scrivner, and S. J. Fallon (2014), Radiocarbon evidence for alternating northern and southern sources of ventilation of the deep Atlantic carbon pool during the last deglaciation, Proc. Nat. Acad. Sci. U.S.A., 111(15), 5480-5484, doi:10.1073/ pnas. 1400668111.

Southon, J., A. L. Noronha, H. Cheng, R. L. Edwards, and Y. Wang (2012), A high-resolution record of atmospheric ${ }^{14} \mathrm{C}$ based on Hulu Cave speleothem H82, Quat. Sci. Rev., 33, 32-42.

Spötl, C., and T. W. Vennemann (2003), Continuous flow isotope ratio mass spectrometric analysis of carbonate minerals, Rapid Commun. Mass Spectrom., 17(9), 1004-1006.

Stern, J. V., and L. E. Lisiecki (2013), Termination 1 timing in radiocarbon dated regional benthic $\delta^{18}$ O stacks, Paleoceanography, 29 , 1127-1142, doi:10.1002/2014PA002700.

Stokes, C. R., and C. D. Clark (2001), Palaeo-ice streams, Quat. Sci. Rev., 20, 1437-1457.

Stoner, J. S., J. E. T. Channell, and C. Hillaire-Marcel (1996), The magnetic signature of rapidly deposited detrital layers from the deep Labrador Sea: Relationship to North Atlantic Heinrich layers, Paleoceanography, 11(3), 309-325, doi:10.1029/96PA00583.

Svensson, A., et al. (2008), A 60000 year Greenland stratigraphic ice core chronology, Clim. Past, 4, 47-57.

Syvitski, J. P. M. (1989), On the deposition of sediment within glacier-influenced fjords: Oceanographic controls, Mar. Geol., 85, 301-329.

Tamburini, F., S. Huon, P. Steinmann, F. E. Grousset, T. Adatte, and K. B. Follmi (2002), Dysaerobic conditions during Heinrich events 4 and 5 : Evidence from phosphorus distribution in a North Atlantic deep-sea core, Geochim. Cosmochim. Acta, 66(23), 4069-4083.

Thomson, J., N. C. Higgs, and T. Clayton (1995), A geochemical criterion for the recognition of Heinrich events and estimation of their depositional fluxes by the ${ }^{230} \mathrm{Th}_{\text {excess }}$ profiling method, Earth Planet. Sci. Lett., 135, 41-56.

Thomson, J., N. C. Higgs, and T. Clayton (1996), Diagenetic redistributions of redox-sensitive elements in northeast Atlantic glacial/interglacial transition sediments, Earth Planet. Sci. Lett., 139, 365-377.

Thomson, J., S. Nixon, C. P. Summerhayes, J. Schönfeld, R. Zahn, and P. Grootes (1999), Implications for sedimentation changes on the lberian Margin over the last two glacial/interglacial transitions from ${ }^{230}$ Th $_{\text {excess }}$ systematics, Earth Planet. Sci. Lett., 165, $255-270$.

Tjallingii, R., U. Röhl, M. Koelling, and T. Bickert (2007), Influence of the water content on X-ray fluorescence core-scanning measurements in soft marine sediments, Geochem. Geophys. Geosyst., 8, Q02004, doi:10.1029/2006GC001393.

Toucanne, S., S. Zaragosi, J.-F. Bourillet, V. Marieu, M. Cremer, M. Kageyama, B. Van Vliet-Lano, F. Eynaud, J.-L. Turon, and P. L. Gibbard (2010), The first estimation of Fleuve Manche palaeoriver discharge during the last deglaciation: Evidence for Fennoscandian ice sheet meltwater flow in the English Channel ca 20-18 ka ago, Earth Planet. Sci. Lett., 290, 459-473.

Toucanne, S., G. Soulet, N. Freslon, R. Silva Jacinto, B. Dennielou, S. Zaragosi, F. Eynaud, J.-F. Bourillet, and G. Bayon (2015), Millennial-scale fluctuations of the European Ice Sheet at the end of the last glacial, and their potential impact on global climate, Quat. Sci. Rev., 123, 113-133.

Treble, P. C., A. K. Schmitt, R. L. Edwards, K. D. McKeegan, and T. M. Harrison (2007), High resolution Secondary lonisation Mass Spectrometry (SIMS) $\delta^{18} \mathrm{O}$ analyses of Hulu Cave speleothem at the time of Heinrich Event 1, Chem. Geol., 238, 197-212.

Vautravers, M. J., and N. J. Shackleton (2006), Centennial-scale surface hydrology off Portugal during marine isotope stage 3: Insights from planktonic foraminiferal fauna variability, Paleoceanography, 21, PA3004, doi:10.1029/2005PA001144.

Vautravers, M. J., N. J. Shackleton, C. Lopez-Martinez, and J. O. Grimalt (2004), Gulf Stream variability during marine isotope stage 3, Paleoceanography, 19, PA2011, doi:10.1029/2003PA000966.

Wang, Y. J., H. Cheng, R. L. Edwards, Z. S. An, J. Y. Wu, C. C. Shen, and J. A. Dorale (2001), A high-resolution absolute-dated Late Pleistocene monsoon record from Hulu Cave, China, Science, 294, 2345-2348.

Wolff, E. W., H. Fischer, and R. Röthlisberger (2009), Glacial terminations as southern warmings without northern control, Nat. Geosci., 2 , 206-209.

Wu, J. Y., Y. J. Wang, H. Cheng, and R. L. Edwards (2009), An exceptionally strengthened East Asian summer monsoon event between 19.9 and 17.1 ka BP recorded in a Hulu stalagmite, Sci. China, Ser. D Earth Sci., 52, 360-368.

Zhang, W., W. Jiangying, Y. Wang, Y. Wang, H. Cheng, X. Kong, and F. Duan (2014), A detailed East Asian monsoon history surrounding the "Mystery Interval" derived from three Chinese speleothem records, Quat. Res., 82, 154-163. 


\section{QPAGUPUBLICATIONS \\ Paleoceanography}

Supporting Information for

Anatomy of Heinrich Layer 1 and its Role in the Last Deglaciation

David A. Hodell ${ }^{1 *}$, Joseph A. Nicholl ${ }^{1}$, Tomaso R. R. Bontognali ${ }^{2}$, Steffan Danino, Javier Dorador ${ }^{4}$, Julian A. Dowdeswell ${ }^{3}$, Joshua Einsle ${ }^{1}$, Holger Kuhlmann ${ }^{5}$, Belen Martrat $^{6}$, Maryline J. Mleneck-Vautravers ${ }^{1}$, Francisco Javier Rodríguez-Tovar ${ }^{4}$, and Ursula Röhl ${ }^{5}$

${ }^{1}$ Godwin Laboratory for Palaeoclimate Research, Department of Earth Sciences, University of Cambridge, Downing Street, Cambridge CB2 3EQ, UK

${ }^{2}$ ETH-Zurich, Geological Institute and Institute of Geochemistry and Petrology, Sonneggstrasse 5, Zurich 8092, Switzerland

${ }^{3}$ Scott Polar Research Institute, Department of Geography, University of Cambridge, Lensfield Road, Cambridge CB2 1ER, UK

${ }^{44}$ Departamento de Estratigrafía y Paleontología, Universidad de Granada, 18002 Granada, Spain

${ }^{5}$ MARUM - Center for Marine Environmental Sciences, University of Bremen, Leobener Strasse, 28359 Bremen, Germany

${ }^{6}$ Department of Environmental Chemistry, Institute of Environmental Assessment and Water Research (IDÆA), Spanish Council for Scientific Research

(CSIC), 08034 Barcelona, Spain

*corresponding author; email: dah73@cam.ac.uk

Contents of this file

Text $\mathrm{S} 1$ to $\mathrm{S} 8$

Figures $\mathrm{S} 1$ to $\mathrm{S} 11$

Tables $\mathrm{S} 1$ to $\mathrm{S} 4$

\section{Additional Supporting Information (Files uploaded separately)}

Captions for Datasets S1 to S3

Captions for Movies S1 to S2 


\section{Introduction}

The supplementary information contains details of the methods (Text S1-S8), 10 supplementary figures (Figures S1-S8) and 4 tables (Tables S1-S4) to support the paper. Visualization of the X-ray CT scans are provided by two movies (Movie S1-S2) of false-color density from the CT scans for Heinrich Event 1 in Holes U1308A and U1308B. Visualization of the sediment coarse fraction (>150 $\mu \mathrm{m}$ ) for the interval from 78 to $91 \mathrm{~cm}$ in Section U1308A-1H-1 is provided through a series of digital microscope images at 10x, 60x and 100x (Data Sets S1-S3). All data are archived with Pangaea (https://www.pangaea.de/) and NOAA (https://www.ncdc.noaa.gov/data-access/paleoclimatology-data) information systems.

\section{Text S1.}

X-ray Fluorescence Core Scanning: XRF Core Scanner data were collected every millimeter down-core with a slit size of $1 \mathrm{~mm} \times 12 \mathrm{~mm}$ using generator settings of $10 \mathrm{kV}$ and $30 \mathrm{kV}$, a current of $1 \mathrm{~mA}(0.25 \mathrm{~mA}$ at $5 \mathrm{~mm} / 10 \mathrm{kV}$ run), and a sampling time of 30 seconds directly at the split core surface of the archive half with Avaatech XRF Core Scanner III at the MARUM - Center for Marine Environmental Sciences, University of Bremen. The split core surface was covered with a 4 micron thin SPEXCerti Prep Ultralene1 foil to avoid contamination of the XRF measurement unit and desiccation of the sediment. The data reported here were acquired by a Canberra X-PIPS Silicon Drift Detector (SDD; Model SXD 15C-150500 ) with $150 \mathrm{eV}$ X-ray resolution, the Canberra Digital Spectrum Analyzer DAS 1000 and an Oxford Instruments 100W Neptune X-ray tube with rhodium $(\mathrm{Rh})$ target material. Raw data spectra were processed by the Analysis of X-ray spectra by Iterative Least square software (WIN AXIL) package from Canberra Eurisys.

\section{Text S2.}

$X$-ray Diffraction $(X R D)$ : Samples for XRD were ground manually to a powder with a mortar and pestle. A small quantity was placed on a level glass plate and acetone was added to level the surface before drying, and placing in a level jig in the x-ray diffractometer. Data were collected in Bragg-Brentano geometry on a D8 Bruker diffractometer equipped with primary Gobbel mirrors for parallel $\mathrm{Cu} \mathrm{Ka}$ X-rays and a Vantec position sensitive linear detector at the University of Cambridge. Collection conditions were: $10-70^{\circ}$ in $2 \theta$, 0.02 step size, 450 seconds/step, divergence slit $0.2 \mathrm{~mm}$. Rietveld refinements were performed with software Topas 4.0 (Cohelo, 2007) to estimate relative abundances of quartz, orthoclase, albite, calcite, dolomite and halite. Crystal structures of all phases were retrieved from the ICSD (Allmann and Hinek, 2007). Reitveld analysis is considered unreliable for minor phases ( $<5 \mathrm{wt} \%)$, with an accuracy of $\pm 1-2 \%$ for major phases for the model used here (Madsen and Scarlett, 2008).

\section{Text S3.}

$X$-ray computerized tomography (CT) scanning and Image Processing: X-ray CT images were acquired with the "General Electric CT Prospeed SX" CT scanner at the MARUM - Center for Marine 
Environmental Sciences, University of Bremen. Overview (scout) scans were processed over a 50-cm interval using $51.2 \times 51.2 \mathrm{~cm}$ field of view (FOV) and generator settings of $120 \mathrm{kV}$ and a current of $80 \mathrm{~mA}$ for the tube power (Fig. S1). To enable a complete 3D visualization $1 \mathrm{~mm}$ thick slice images with a FOV of $12 \times 12 \mathrm{~cm}$ have been obtained in $1 \mathrm{~mm}$ down-core resolution using $120 \mathrm{kV}$ and $100 \mathrm{~mA}$ to ensure maximum quality of the images. Images were saved as greyscale DICOM (Digital Imaging and Communication in Medicine) files, in sets of 50 images (50-mm sections of core).

The resulting images were processed with the open source image processing package FIJI that was employed for visualization and quantification of the CT scans of the sediment cores. In order to calculate both particle statistics as well as average core density, the x-ray tomographic volume data was segmented to identify and label pixels as either high-density IRD grains or as low-density background sediment. The first step in the segmentation process creates a mask to isolate the sediment material from the core liner running the length of the core. Once the core liner has been removed, we use the absorption intensity as a proxy for density measurements. We determine the average density of the core by averaging the pixel intensity for each 1-mm slice of the reconstructed volume, removing the background and cracks. We scale each slice density tomogram to the overall mean IRD, which produces the density curve shown in Fig. 4.

Movies of the CT X-ray scans of the two cores were generated by loading X-ray reconstruction image stacks into the open-source, multi-platform data analysis and visualization application, Paraview (Fig. S2 and S3 and Movies S1 and S2). The resulting volume render of the recognition is made using color transfer map based on the normalized x-ray absorption intensity. This gives us a relative density map, with higher density being assigned a low transparency by the color transfer function. Using the animation tools in Paraview we are then able to record a camera orbit around the cores.

IRD particle sizes are determined by segmenting the Heinrich core tomogram for the high density voxels. The exact value of the pixel intensity that corresponds to IRD varies slightly from hole to hole as well as within the core. For analysis, we selected pixel intensities that would extract the largest grains in the Heinrich layers. This allows us to determine how these IRD grains relate to the event at the expense of high spatial resolution of the smallest particles. Owing to the large amount of high-density material in the Heinrich layers, it is a non-trivial task to segment with a single grey scale within and outside of the layer. Moreover as particle size becomes smaller, particles of the same material will absorb less. Advanced image processing methods potentially would allow for the segmentation of small particles within the Heinrich event as well as in sediments on either side of the layer. The resulting binary tomogram of the stack represents the largest most absorbing particles in the core. Using BoneJ we were able to obtain particle volume and orientation information for every particle that it labels [Doube et al., 2010]. For orientation information we use the best-fit ellipsoid unit vectors. The orientation of the ellipsoid axes indicate that the 
majority of the IRD grains are oriented with their major and intermediate axes parallel to the sea floor and their minor axes vertically upwards (Figs. S4, S4, S6).

\section{Text S4.}

Core Sampling and IRD Point Counting: Discrete sampling of the core was carried out at $0.5-\mathrm{cm}$ intervals over the interval of Heinrich Event 1 in Hole U1308A. Samples were taken from the working half of the core, the same half of core that was used for XRF measurements, in order to better correlate the sample measurements and XRF data. Point counting of IRD was carried out using an optical binocular microscope. Samples were sieved and the $>150 \mu \mathrm{m}$ size fraction was split into subsamples of at least 300 grains. Data are expressed as \%IRD and \% detrital carbonate, where \% IRD includes all lithics including detrital carbonate.

\section{Text S5.}

Planktonic foraminfera assemblages: We used a standard method for counting foraminifera (Vautravers et al., 2004; Vautravers and Shackleton, 2006). The size fraction $>150 \mu \mathrm{m}$ was subsampled using a micro-splitter until 1/32 of the original sample remained. This yielded between 300 and 600 grains. Each split-sample was spread on a gridded tray for identification and enumeration of planktonic foraminifera (Table S1). Particles were identified as planktonic foraminifera following the taxonomy of Kennett and Srinivasan (1983), planktonic foraminifer fragments, benthic foraminifera and ostracods, radiolarian, and ice-rafted detritus (undifferentiated).

\section{Text S6.}

Stable isotopes: Oxygen and carbon isotopes were measured on the planktonic foraminifer $N$. pachyderma (sin). Prior to analysis, foraminifer specimens were meticulously cleaned to remove any fine detrital carbonate from the test, which has been shown to have very low $\delta^{18} 0$ values (Hodell and Curtis, 2008). The samples were crushed between two glass plates to break the foraminifer tests, and any obvious detrital material was removed. To remove organic matter, foraminifer tests were either crushed and soaked in a solution of $1 \%$ hydrogen peroxide for $30 \mathrm{~min}$ in individual vials or roasted in vacuo in an oven for 1 hour at $400^{\circ} \mathrm{C}$. The samples were then rinsed with UHQ $\mathrm{H}_{2} \mathrm{O}$ and fine particles were suspended by ultrasonication, before being pipetted off. Acetone was added and the samples placed in an ultra-sonic bath for $10 \mathrm{~s}$, after which the liquid was carefully decanted to remove any contaminants. The samples were dried in an oven at $50^{\circ} \mathrm{C}$ overnight.

For benthic foraminifer, Cibicidoides wuellerstorfi, Cibicidoides kullenbergi, and Uvigerina peregrina were picked from the $>150 \mu \mathrm{m}$ fraction. Oxygen isotopes of Cibicidoides were corrected to Uvigerina by adding $0.64 \%$ (Fig. 10). Carbon isotopes of Uvigerina were disregarded as they reflect pore-water 
values owing to the shallow infaunal habitat of this species. Isotopic ratios of foraminifer calcite were measured using a ThermoScientific MAT253 mass spectrometer fitted with a Kiel device. Analytical precision is estimated to be $\pm 0.08 \%$ for $\delta^{18} 0$ and $\pm 0.06 \%$ for $\delta^{13} \mathrm{C}$, respectively.

Oxygen isotopes of bulk carbonate were measured using a ThermoScientific GasBench II, equipped with a CTC autosampler coupled to a DeltaV mass spectrometer (Spötl and Vennemann, 2003). Analytical precision is estimated to be $\pm 0.1 \%$ for $\delta^{18} 0$ by repeated analysis of the Carrara Marble standard. All isotope measurements were made in the Godwin Laboratory, University of Cambridge, are reported relative to Vienna Pee Dee Belemnite (VPDB).

\section{Text S7.}

Ichnology: Ichnological analysis was performed in Holes U1308A and U1308B in the parts of the cores that contain Heinrich Event 1, corresponding to intervals (7 to 18) in Figure 11. All CT images were analyzed in each of the intervals (12 images per interval) using established methods (Dorador and Rodríguez-Tovar, 2014; Dorador et al., 2014a, b; Rodríguez-Tovar and Dorador, 2015). Ichnological analysis included: (i) differentiation between biodeformational structures and trace fossils, (ii) ichnotaxonomical classification of the trace fossils, (iii) relative abundance, (iv) cross-cutting relationships, (v) bioturbation index (BI, according to Taylor and Goldring, 1993), and (vi) ichnofabric characterization.

\section{Text S8.}

Radiocarbon and Age Model: Samples for dating were analyzed at the NERC radiocarbon facility in East Kilbride, Scotland (UK) and the W. M. Keck Carbon Cycle Accelerator Mass Spectrometry Laboratory in Irvine, California (USA) (Table S2). Prior to analysis, foraminiferal specimens were cleaned using a modified version of the clay- and organic removal cleaning steps described by Barker et al. (2003). This cleaning was performed to remove any organic material and, especially, to remove fine detrital carbonate that, being radiocarbon dead, would contaminate the measurements causing older ages. The samples were crushed between two glass plates to break the foraminifer tests, and any obvious detrital material was removed. The samples were then rinsed with UHQ $\mathrm{H}_{2} \mathrm{O}$ and clay minerals were suspended by ultrasonication, before being pipetted off. This step was performed five times, until the $\mathrm{H}_{2} \mathrm{O}$ in the sample vials appeared clear. The methanol cleaning step in this procedure was omitted to avoid contamination. To remove organic material, the samples were rinsed with $1 \%$ $\mathrm{H}_{2} \mathrm{O}_{2}$ solution and left for 10 minutes in a hot water bath with occasional agitation of the samples by ultrasonification. The liquid was then pipetted away. This step was performed twice. Samples were then dried in an oven. 
The chronology for Section U1308A-1H-1 relies on eight radiocarbon dates of $N$. pachyderma ( $\sin$ ) from Hole U1308A (Table S2) combined with 15 radiocarbon dates from Bond et al. [1992] (Table S3). We have derived the calibrated age model using Marine13 [Reimer et al., 2013] within a Bayesian modeling (BACON) framework [Blaauw and Christen, 2011]. We used estimates of high-latitude North Atlantic reservoir ages and errors given by Stern and Lisiecki [2014]. Model parameters for BACON included an accumulation shape of 1.5 , memory strength of 4 , memory mean of 0.7 that were applied to $150 \times 0.5 \mathrm{~cm}$ sections. The age model was interpolated at $0.25 \mathrm{~cm}$ increments within a Monte Carlo framework and a 95\% confidence interval. Samples are plotted using the weighted mean calibrated years BP (Table S4).

References

Allmann R., and R. Hinek (2007), The introduction of structure types into the Inorganic Crystal Structure Database ICSD, Acta Cryst, A63, 412-417.

Barker, S., M. Greaves, and H. Elderfield (2003), A study of cleaning procedures used for foraminiferal $\mathrm{Mg} / \mathrm{Ca}$ paleothermometry, Geochem. Geophys. Geosyst., 4(9), 8407, doi:10.1029/2003GC000559.

Blaauw, M., and J. A. Christen (2011), Flexible paleoclimate age-depth models using an autoregressive gamma process, Bayesian Analysis, 6, 457-474.

Cohelo, A. (2007), TOPAS-Academic, Coelho Software, Brisbane, Australia.

Dorador, J., and F.J. Rodríguez-Tovar (2014), A novel application of digital image treatment by quantitative pixel analysis to trace fossil research in marine cores, Palaios, 29, 533-538.

Dorador, J., F. J. Rodríguez-Tovar, and IODP Expedition 339 Scientists (2014a), Digital image treatment applied to ichnological analysis of marine core sediments, Facies, 60, 39-44. 
Dorador, J., F. J. Rodríguez-Tovar, and IODP Expedition 339 Scientists (2014b), Quantitative estimation of bioturbation based on digital image analysis, Marine Geology, $349,55-60$.

Doube, M., M. M. Kłosowski, I. Arganda-Carreras, F. P. Cordelieres, R. P. Dougherty, J. S. Jackson, B. Schmid, J. R. Hutchinson, S. J. Shefelbine, (2010), BoneJ: Free and extensible bone image analysis in ImageJ, Bone, 47(6), 1076-1079.

Hodell, D. A., and J. H. Curtis (2008), Oxygen and carbon isotopes of detrital carbonate in North Atlantic Heinrich events, Mar. Geol., 256, 30-35, doi:10.1016/j.margeo.2008.09.010.

Kennett, J. P. and M. S. Srinivasan (1983), Neogene Planktonic Foraminifera: A Phylogenetic Atlas, Hutchinson Ross, Stroudsburg, Pennsylvania.

Madsen, I.C., and N. V. Y Scarlett (2008), Quantitative Phase Analysis. In Powder Diffraction: Theory and Practice, edited by Dinnabier, R.E., Royal Society of Chemistry.

Reimer, P.J., et al. (2013), IntCal13 and Marine13 radiocarbon age calibration curves 050,000 yr cal BP, Radiocarbon 55(4), 1869-1887.

Rodríguez-Tovar, F. J., and J. Dorador (2015), Ichnofabric characterization in cores: A method of digital image treatment, Annales Societatis Geologorum Poloniae, 85, 465471.

Spötl, C. and T. W. Vennemann (2003), Continuous flow isotope ratio mass spectrometric analysis of carbonate minerals, Rapid Communications in Mass Spectrometry, 17 (9), 1004-1006.

Stern, J. V., and L. E. Lisiecki (2014), Termination 1 timing in radiocarbon dated regional benthic $\delta^{18} \mathrm{O}$ stacks, Paleoceanography, 29, 1127-1142. 
doi:10.1002/2014PA002700

Tamburini, F., S. Huon, P. Steinmann, F. E. Grousset, T. Adatte, and K. B. Follmi, K. B. (2002), Dysaerobic conditions during Heinrich events 4 and 5: Evidence from phosphorus distribution in a North Atlantic deep-sea core, Geochim. Cosmochim. Ac., 66(23), 4069-4083.

Vautravers, M. J., N. J. Shackleton, C. Lopez-Martinez, and J. O. Grimalt (2004), Gulf Stream variability during marine isotope stage 3, Paleoceanography, 19, PA2011, doi:10.1029/2003PA000966.

Vautravers, M. J. and N. J. Shackleton (2006), Centennial-scale surface hydrology off Portugal during marine isotope stage 3: Insights from planktonic foraminiferal fauna variability, Paleoceanography, 21, PA3004, doi:10.1029/2005PA001144.

Table S1. Species list of planktonic foraminifera counted in Section U1308A-1H-1

Neogloboquadrina pachyderma (sinistral)

Neogloboquadrina pachyderma (dextral)

Globigerina bulloides

Globorotalia inflata

Globogerinita glutinata

Turborotalia quinqueloba

Globorotalia scitula

Globigerina falconensis

Glogogerina rubescens

Globigerinoides ruber

Globorotalia truncatulinoides

Hastigerina aequilateralis

Beela digitata 
Table S2. Radiocarbon dates in Section U1308A-1H-1.

\begin{tabular}{|c|c|c|c|c|c|c|c|c|c|}
\hline Laboratory ID & Hole-Core-Section & Depth & Species & fraction & \pm & $\mathrm{D}^{14} \mathrm{C}$ & \pm & $14 \mathrm{C}$ years & \pm \\
\hline & & $(\mathrm{cm})$ & & & & & & \begin{tabular}{|l} 
(uncorrected) \\
\end{tabular} & \\
\hline 180648 & U1308A-1H-1 & 78.25 & N. pachyderma (s) & 0.2000 & 0.0007 & -800.0 & 0.7 & 12930 & 30 \\
\hline 180649 & U1308A-1H-1 & 78.25 & G. bulloides & 0.2135 & 0.0007 & -786.5 & 0.7 & 12405 & 25 \\
\hline 180650 & U1308A-1H-1 & 80.25 & N. pachyderma (s) & 0.1874 & 0.0008 & -812.6 & 0.8 & 13450 & 40 \\
\hline 180651 & U1308A-1H-1 & 80.25 & G. bulloides & 0.2065 & 0.0006 & -793.5 & 0.6 & 12675 & 25 \\
\hline 180652 & U1308A-1H-1 & 81.75 & N. pachyderma (s) & 0.1827 & 0.0006 & -817.3 & 0.6 & 13655 & 30 \\
\hline 180653 & U1308A-1H-1 & 81.75 & G. bulloides & 0.2028 & 0.0007 & -797.2 & 0.7 & 12815 & 30 \\
\hline 1517.1010 & U1308A-1H-1 & 82.75 & N. pachyderma (s) & 0.1897 & 0.0010 & & & 13355 & 42 \\
\hline 180655 & U1308A-1H-1 & 85.25 & G. bulloides & 0.2036 & 0.0006 & -796.4 & 0.6 & 12785 & 30 \\
\hline 180654 & U1308A-1H-1 & 85.75 & N. pachyderma $(\mathrm{s})$ & 0.1927 & 0.0006 & -807.3 & 0.6 & 13230 & 30 \\
\hline 180656 & U1308A-1H-1 & 86.75 & N. pachyderma (s) & 0.1769 & 0.0007 & -823.1 & 0.7 & 13915 & 30 \\
\hline 1517.1010 & U1308A-1H-1 & 88.75 & N. pachyderma (s) & 0.1592 & 0.0009 & & & 14762 & 45 \\
\hline 180657 & U1308A-1H-1 & 91.25 & N. pachyderma (s) & 0.1374 & 0.0006 & -862.6 & 0.6 & 15945 & 35 \\
\hline
\end{tabular}

Table S3. Combined radiocarbon dates from Holes U1308A and 609. The reservoir correction is taken from Stern and Lisiecki (2014).

\begin{tabular}{|c|c|c|c|c|c|}
\hline Depth in Section 1308A-1H-1 & depth in 609 & Radiocarbon age & error & Reference & Reservoir Correction \\
\hline (cm) & (cm) & 14C years (uncorrected) & \pm & & (years) \\
\hline 69.6 & 64 & 12380 & 120 & Bond et al. (1992) & 360 \\
\hline 70.184 & 65 & 11580 & 190 & Bond et al. (1992) & 390 \\
\hline 72.965 & 69.5 & 11420 & 190 & Bond et al. (1992) & 390 \\
\hline 78.25 & & 12930 & 30 & this study & 230 \\
\hline 79.258 & 74 & 12750 & 220 & Bond et al. (1992) & 130 \\
\hline 80.25 & & 13450 & 40 & this study & 130 \\
\hline 81.75 & & 13655 & 30 & this study & 245 \\
\hline 82.056 & 76 & 13890 & 220 & Bond et al. (1992) & 150 \\
\hline 82.75 & & 13355 & 42 & this study & 150 \\
\hline 85.75 & & 13230 & 30 & this study & 180 \\
\hline 86.75 & & 13915 & 30 & this study & 150 \\
\hline 88.75 & & 14762 & 45 & this study & 720 \\
\hline 91.25 & & 15945 & 35 & this study & 750 \\
\hline 91.603 & 84.5 & 14990 & 230 & Bond et al. (1992) & 720 \\
\hline 94.305 & 87.5 & 16360 & 240 & Bond et al. (1992) & 440 \\
\hline 94.305 & 90.5 & 16760 & 150 & Bond et al. (1992) & 320 \\
\hline 104.87 & 98.5 & 17360 & 120 & Bond et al. (1992) & 260 \\
\hline 112.08 & 106 & 19340 & 220 & Bond et al. (1992) & -130 \\
\hline 117.35 & 110.5 & 20370 & 330 & Bond et al. (1992) & -340 \\
\hline 118.585 & 111.5 & 20950 & 260 & Bond et al. (1992) & 40 \\
\hline 119.82 & 112.5 & 21510 & 220 & Bond et al. (1992) & 230 \\
\hline 123.26 & 115.5 & 21770 & 220 & Bond et al. (1992) & 230 \\
\hline 127.05 & 119 & 22780 & 340 & Bond et al. (1992) & 190 \\
\hline 142.5 & 139 & 25660 & 440 & Bond et al. (1992) & 300 \\
\hline
\end{tabular}

Table S4. The age model interpolated at $0.25 \mathrm{~cm}$ increments in Section U1308A-1H-1 derived using a Bayesian modeling (BACON) framework (Blaauw and Christen, 2011).

\begin{tabular}{|r|c|c|c|c|}
\hline $\begin{array}{c}\text { depth in } \\
\text { U1308A-1H-1 }\end{array}$ & min Age & max Age & $\begin{array}{c}\text { median } \\
\text { Age }\end{array}$ & $\begin{array}{c}\text { wmean } \\
\text { Age }\end{array}$ \\
\hline \multicolumn{1}{|c|}{$(\mathbf{c m})$} & $\mathbf{( k a )}$ & $\mathbf{( k a )}$ & $\mathbf{( k a )}$ & $\mathbf{( k a )}$ \\
\hline 50 & 5118.7 & 11742.9 & 9206.9 & 9054.4 \\
\hline 50.25 & 5215.4 & 11756 & 9253.2 & 9103.5 \\
\hline 50.5 & 5338.2 & 11781.5 & 9301.7 & 9152.1 \\
\hline 50.75 & 5460.1 & 11807.1 & 9350.2 & 9202.3 \\
\hline 51 & 5522.8 & 11835.4 & 9402.7 & 9252.5 \\
\hline 51.25 & 5620.5 & 11853.6 & 9449.8 & 9300.5 \\
\hline 51.5 & 5699.5 & 11876.2 & 9501.8 & 9351 \\
\hline 51.75 & 5792.5 & 11896.1 & 9549.3 & 9400.5 \\
\hline
\end{tabular}




\begin{tabular}{|c|c|c|c|c|}
\hline 52 & 5866.6 & 11920.2 & 9597.8 & 9449.4 \\
\hline 52.25 & 5965.9 & 11946.2 & 9641.3 & 9499.3 \\
\hline 52.5 & 6034.2 & 11961.3 & 9692.4 & 9547.4 \\
\hline 52.75 & 6108.8 & 11985.3 & 9745.7 & 9597.5 \\
\hline 53 & 6177.5 & 12013.8 & 9798.7 & 9648.3 \\
\hline 53.25 & 6228.7 & 12042.7 & 9851.6 & 9697.6 \\
\hline 53.5 & 6312.5 & 12071.6 & 9899.3 & 9746.4 \\
\hline 53.75 & 6344.5 & 12113.2 & 9952.4 & 9794.5 \\
\hline 54 & 6410 & 12142.7 & 10006.3 & 9845.4 \\
\hline 54.25 & 6476.8 & 12164.7 & 10058 & 9894.3 \\
\hline 54.5 & 6517.1 & 12214.1 & 10102.5 & 9943.1 \\
\hline 54.75 & 6575.7 & 12260 & 10150.9 & 9992.2 \\
\hline 55 & 6663.8 & 12308.7 & 10197.6 & 10042.1 \\
\hline 55.25 & 6751.3 & 12329.3 & 10241.2 & 10087.6 \\
\hline 55.5 & 6842.9 & 12349 & 10283.9 & 10133.4 \\
\hline 55.75 & 6928.6 & 12365.7 & 10329.2 & 10179.2 \\
\hline 56 & 7017.1 & 12383.7 & 10375.8 & 10226 \\
\hline 56.25 & 7085.5 & 12407.9 & 10423.8 & 10273 \\
\hline 56.5 & 7173.2 & 12433.4 & 10469.9 & 10320 \\
\hline 56.75 & 7255.1 & 12457.5 & 10521.1 & 10367.3 \\
\hline 57 & 7335.8 & 12471 & 10566.3 & 10413.6 \\
\hline 57.25 & 7420.4 & 12502.2 & 10616.3 & 10458.7 \\
\hline 57.5 & 7508.7 & 12521.8 & 10660.8 & 10507 \\
\hline 57.75 & 7579.3 & 12550.7 & 10708.8 & 10554 \\
\hline 58 & 7657.8 & 12576.4 & 10756.2 & 10600.7 \\
\hline 58.25 & 7732.2 & 12605.1 & 10804.3 & 10646.9 \\
\hline 58.5 & 7820.5 & 12635.1 & 10847.3 & 10694.2 \\
\hline 58.75 & 7898.1 & 12669.5 & 10901.8 & 10743.9 \\
\hline 59 & 7973.1 & 12705.2 & 10946.8 & 10789.9 \\
\hline 59.25 & 8036.6 & 12743.7 & 10993.3 & 10836.6 \\
\hline 59.5 & 8087.4 & 12777.4 & 11040.3 & 10882.9 \\
\hline 59.75 & 8148.5 & 12828.6 & 11087.1 & 10931 \\
\hline 60 & 8206 & 12881.2 & 11131.7 & 10979 \\
\hline 60.25 & 8305.9 & 12893.8 & 11179.9 & 11027.5 \\
\hline 60.5 & 8390 & 12905.9 & 11225.1 & 11075.8 \\
\hline 60.75 & 8483.5 & 12920.7 & 11270.2 & 11124.6 \\
\hline 61 & 8568.7 & 12937.9 & 11318.1 & 11172.2 \\
\hline 61.25 & 8659 & 12956.6 & 11364.1 & 11221.4 \\
\hline 61.5 & 8738 & 12973.4 & 11413.5 & 11271.4 \\
\hline 61.75 & 8821.2 & 12993.8 & 11464.9 & 11321.6 \\
\hline 62 & 8889.4 & 13011.5 & 11516.6 & 11370.8 \\
\hline
\end{tabular}




\begin{tabular}{|c|c|c|c|c|}
\hline 62.25 & 8960.8 & 13038.9 & 11567.9 & 11420 \\
\hline 62.5 & 9039.5 & 13057.8 & 11618.9 & 11467.4 \\
\hline 62.75 & 9106 & 13080.2 & 11669.6 & 11517.6 \\
\hline 63 & 9179.2 & 13106 & 11716.6 & 11566.6 \\
\hline 63.25 & 9247.4 & 13131.7 & 11769.1 & 11615.7 \\
\hline 63.5 & 9315 & 13163.3 & 11817.9 & 11664.7 \\
\hline 63.75 & 9366.7 & 13192.8 & 11869 & 11714.1 \\
\hline 64 & 9429.4 & 13230.9 & 11917.2 & 11764.6 \\
\hline 64.25 & 9491.8 & 13264.3 & 11967.3 & 11814 \\
\hline 64.5 & 9541.7 & 13300.8 & 12012.5 & 11861 \\
\hline 64.75 & 9597.4 & 13339.5 & 12061 & 11910 \\
\hline 65 & 9644.9 & 13393.4 & 12110.6 & 11959.7 \\
\hline 65.25 & 9797.1 & 13401.7 & 12153.6 & 12007 \\
\hline 65.5 & 9924 & 13423 & 12187 & 12053.1 \\
\hline 65.75 & 10065.3 & 13447.7 & 12230.5 & 12101.7 \\
\hline 66 & 10208.3 & 13448.7 & 12269.7 & 12148.6 \\
\hline 66.25 & 10335.2 & 13467 & 12306.7 & 12196.3 \\
\hline 66.5 & 10462.2 & 13487.9 & 12347.3 & 12243.8 \\
\hline 66.75 & 10580.4 & 13503.5 & 12384.9 & 12290.4 \\
\hline 67 & 10716.4 & 13519.4 & 12427.4 & 12337.4 \\
\hline 67.25 & 10816.2 & 13533.9 & 12465.2 & 12385.4 \\
\hline 67.5 & 10929.1 & 13562.4 & 12508.5 & 12433.3 \\
\hline 67.75 & 11026.7 & 13577.1 & 12551.1 & 12480.7 \\
\hline 68 & 11107.7 & 13594.9 & 12591.1 & 12528.1 \\
\hline 68.25 & 11187.2 & 13622.7 & 12632.5 & 12575.6 \\
\hline 68.5 & 11267.1 & 13644.9 & 12675.8 & 12623.4 \\
\hline 68.75 & 11343.8 & 13673.9 & 12719.6 & 12672.5 \\
\hline 69 & 11427.1 & 13711.4 & 12768.5 & 12723.6 \\
\hline 69.25 & 11493.6 & 13746.5 & 12819.7 & 12774.9 \\
\hline 69.5 & 11560.2 & 13789.4 & 12866.3 & 12825.9 \\
\hline 69.75 & 11602.4 & 13840.7 & 12915.9 & 12876.2 \\
\hline 70 & 11659.6 & 13883.2 & 12967.6 & 12926.8 \\
\hline 70.25 & 11744.5 & 13906.3 & 12997.3 & 12961.3 \\
\hline 70.5 & 11818.2 & 13931.9 & 13029.7 & 12997.1 \\
\hline 70.75 & 11880 & 13950 & 13060.7 & 13032.7 \\
\hline 71 & 11946.1 & 13979.3 & 13092.3 & 13068.6 \\
\hline 71.25 & 12014 & 14000.6 & 13124.9 & 13104.2 \\
\hline 71.5 & 12071.2 & 14036 & 13154.5 & 13140.5 \\
\hline 71.75 & 12128.1 & 14056.1 & 13187 & 13176.4 \\
\hline 72 & 12183.7 & 14096 & 13217.6 & 13212.2 \\
\hline 72.25 & 12238.9 & 14129.8 & 13249.5 & 13248.3 \\
\hline
\end{tabular}




\begin{tabular}{|c|c|c|c|c|}
\hline 72.5 & 12296.2 & 14164.6 & 13280.8 & 13284.4 \\
\hline 72.75 & 12348.6 & 14204.2 & 13314.1 & 13320.6 \\
\hline 73 & 12394.3 & 14249.2 & 13346.9 & 13357.4 \\
\hline 73.25 & 12433.5 & 14294 & 13378.5 & 13393.7 \\
\hline 73.5 & 12471.1 & 14344.6 & 13409.9 & 13429.6 \\
\hline 73.75 & 12507.4 & 14401.2 & 13443.5 & 13465.9 \\
\hline 74 & 12541.4 & 14456.4 & 13477.4 & 13502.9 \\
\hline 74.25 & 12578.8 & 14522.6 & 13511.1 & 13539.3 \\
\hline 74.5 & 12601.5 & 14588.6 & 13542.7 & 13575.4 \\
\hline 74.75 & 12631.5 & 14655.4 & 13574.3 & 13611.9 \\
\hline 75 & 12661.1 & 14725.4 & 13608 & 13648.8 \\
\hline 75.25 & 12757.3 & 14756.6 & 13663 & 13705.1 \\
\hline 75.5 & 12851.6 & 14780.1 & 13720.2 & 13762.3 \\
\hline 75.75 & 12941.1 & 14804.3 & 13778.3 & 13819.8 \\
\hline 76 & 13031.4 & 14828.5 & 13833.8 & 13876.4 \\
\hline 76.25 & 13117 & 14864.1 & 13895 & 13933.7 \\
\hline 76.5 & 13193.2 & 14899.2 & 13956.7 & 13990.3 \\
\hline 76.75 & 13262.2 & 14939.8 & 14015.6 & 14047.6 \\
\hline 77 & 13327.9 & 14972.1 & 14077.1 & 14105 \\
\hline 77.25 & 13384.8 & 15017.5 & 14139 & 14162.2 \\
\hline 77.5 & 13444.7 & 15060.4 & 14200.8 & 14219.6 \\
\hline 77.75 & 13495.9 & 15102.8 & 14261.6 & 14277 \\
\hline 78 & 13551.9 & 15149.4 & 14322.7 & 14335.5 \\
\hline 78.25 & 13603.6 & 15202 & 14383.6 & 14393.4 \\
\hline 78.5 & 13653.8 & 15253.9 & 14443.9 & 14450.9 \\
\hline 78.75 & 13699.1 & 15322.8 & 14505.1 & 14509 \\
\hline 79 & 13743.5 & 15391.8 & 14562.5 & 14566.7 \\
\hline 79.25 & 13778.4 & 15472.5 & 14620.2 & 14624 \\
\hline 79.5 & 13806.7 & 15555 & 14676.7 & 14681.5 \\
\hline 79.75 & 13833.7 & 15640.1 & 14732.6 & 14738.8 \\
\hline 80 & 13862.9 & 15725.7 & 14788 & 14795.8 \\
\hline 80.25 & 13954.1 & 15753 & 14838.5 & 14846.4 \\
\hline 80.5 & 14038.8 & 15781.1 & 14886.2 & 14896.2 \\
\hline 80.75 & 14113.3 & 15800.9 & 14939.5 & 14945.8 \\
\hline 81 & 14180 & 15826.7 & 14989.8 & 14995.8 \\
\hline 81.25 & 14244.6 & 15853.9 & 15042.2 & 15045.7 \\
\hline 81.5 & 14304.2 & 15881 & 15096.7 & 15096.8 \\
\hline 81.75 & 14363.7 & 15913.5 & 15150.5 & 15147.5 \\
\hline 82 & 14414.5 & 15949.8 & 15204.2 & 15198.6 \\
\hline 82.25 & 14460.8 & 15991.9 & 15258.2 & 15249.2 \\
\hline 82.5 & 14500.7 & 16031.2 & 15314.4 & 15299.3 \\
\hline
\end{tabular}




\begin{tabular}{|c|c|c|c|c|}
\hline 82.75 & 14541.5 & 16083.6 & 15368.3 & 15349.5 \\
\hline 83 & 14582.2 & 16128 & 15421.5 & 15399.4 \\
\hline 83.25 & 14617.1 & 16182.3 & 15472.9 & 15449.4 \\
\hline 83.5 & 14649.6 & 16239.7 & 15522.8 & 15500 \\
\hline 83.75 & 14675.5 & 16299.5 & 15573.5 & 15550.3 \\
\hline 84 & 14703 & 16370.4 & 15620 & 15600.4 \\
\hline 84.25 & 14729.4 & 16448.5 & 15670.9 & 15650.9 \\
\hline 84.5 & 14751.3 & 16534.7 & 15720.6 & 15701.3 \\
\hline 84.75 & 14782.7 & 16618.5 & 15765.1 & 15751.3 \\
\hline 85 & 14808.6 & 16705.9 & 15811.5 & 15801.8 \\
\hline 85.25 & 14885.7 & 16732.1 & 15859.4 & 15850.5 \\
\hline 85.5 & 14963.8 & 16760 & 15901.2 & 15898.7 \\
\hline 85.75 & 15032.3 & 16793.6 & 15949.9 & 15947.5 \\
\hline 86 & 15108.8 & 16833.6 & 15998.1 & 15996.8 \\
\hline 86.25 & 15183.2 & 16874.7 & 16044.2 & 16045.4 \\
\hline 86.5 & 15247.3 & 16913.6 & 16092.1 & 16094.8 \\
\hline 86.75 & 15307.6 & 16953.6 & 16140.7 & 16144 \\
\hline 87 & 15351.7 & 16994.6 & 16186.9 & 16192.8 \\
\hline 87.25 & 15404 & 17044 & 16234.2 & 16241.7 \\
\hline 87.5 & 15451.2 & 17095 & 16285.6 & 16291.4 \\
\hline 87.75 & 15491.1 & 17143.8 & 16333.2 & 16340.7 \\
\hline 88 & 15538 & 17201.7 & 16380 & 16389.2 \\
\hline 88.25 & 15576.4 & 17265.9 & 16428.8 & 16438.2 \\
\hline 88.5 & 15609.3 & 17334.8 & 16477.6 & 16485.8 \\
\hline 88.75 & 15647 & 17409.7 & 16527.1 & 16535.5 \\
\hline 89 & 15683.3 & 17487.2 & 16573.9 & 16584.7 \\
\hline 89.25 & 15715.7 & 17562.7 & 16620.4 & 16633.6 \\
\hline 89.5 & 15751.9 & 17645.6 & 16666.8 & 16682.6 \\
\hline 89.75 & 15781.3 & 17731.4 & 16711.6 & 16731 \\
\hline 90 & 15811.9 & 17816.8 & 16755.7 & 16780.5 \\
\hline 90.25 & 15963.8 & 17864.4 & 16850.7 & 16874.7 \\
\hline 90.5 & 16105.9 & 17908.9 & 16946.7 & 16969.4 \\
\hline 90.75 & 16239.8 & 17962.3 & 17043.4 & 17064 \\
\hline 91 & 16372.2 & 18011.7 & 17141.9 & 17159 \\
\hline 91.25 & 16491.9 & 18069.9 & 17239.8 & 17254.3 \\
\hline 91.5 & 16605.5 & 18133.5 & 17336.8 & 17350.2 \\
\hline 91.75 & 16715.3 & 18197.4 & 17432.8 & 17446.1 \\
\hline 92 & 16819.8 & 18269.1 & 17529 & 17541.4 \\
\hline 92.25 & 16914.1 & 18357.9 & 17627.9 & 17638 \\
\hline 92.5 & 16999.9 & 18450.5 & 17727.5 & 17733.4 \\
\hline 92.75 & 17075.4 & 18543.5 & 17827.9 & 17829.2 \\
\hline
\end{tabular}




\begin{tabular}{|r|r|r|r|r|}
\hline 93 & 17145.2 & 18647.4 & 17924.5 & 17924.4 \\
\hline 93.25 & 17210.2 & 18753.6 & 18024 & 18019.3 \\
\hline 93.5 & 17267.3 & 18868 & 18119 & 18114.2 \\
\hline 93.75 & 17320.4 & 18992.4 & 18216.4 & 18208.8 \\
\hline 94 & 17377.5 & 19120.9 & 18310.4 & 18303.6 \\
\hline 94.25 & 17427 & 19259.1 & 18403.1 & 18398.1 \\
\hline 94.5 & 1746.3 & 19400.9 & 18498.5 & 18492.9 \\
\hline 94.75 & 17527.6 & 19539.8 & 18591.7 & 18586.9 \\
\hline 95 & 17563.2 & 19687.8 & 18685.7 & 18681.6 \\
\hline 95.25 & 17674 & 19727.7 & 18744.5 & 18743.9 \\
\hline 95.5 & 17777.5 & 19771.9 & 18805.1 & 18805.8 \\
\hline 95.75 & 17877.3 & 19809.4 & 18866.9 & 18867.7 \\
\hline 96 & 17960.7 & 19854.8 & 18929.2 & 18929.3 \\
\hline 96.25 & 18033.5 & 19902.9 & 18993.5 & 18991.3 \\
\hline 96.5 & 18095.5 & 19954 & 19058.4 & 19053.4 \\
\hline 96.75 & 18151.2 & 20013.8 & 19122.3 & 19114.7 \\
\hline 97 & 18192.5 & 20080.9 & 19187 & 19176.3 \\
\hline 97.25 & 18240.4 & 20157.1 & 19249.3 & 19238.2 \\
\hline 97.5 & 18285.4 & 20249.4 & 19310.4 & 19300.2 \\
\hline 97.75 & 18322.6 & 20356.7 & 19365.6 & 19361.8 \\
\hline 98 & 18354.9 & 20462.8 & 19426.8 & 19425 \\
\hline 98.25 & 18390.2 & 20565 & 19481.3 & 19485.4 \\
\hline 98.5 & 18424.5 & 20685.3 & 19538.1 & 19548.1 \\
\hline 98.75 & 18444.7 & 20813.2 & 19593.2 & 19608.7 \\
\hline 99 & 18469.2 & 20953.9 & 19645.7 & 19670.5 \\
\hline 99.25 & 18489.7 & 21093 & 19696.6 & 19730.9 \\
\hline 99.5 & 18515.5 & 21224.7 & 19748.4 & 19791.9 \\
\hline 99.75 & 18533.7 & 21361.5 & 19802.8 & 19852.8 \\
\hline 100 & 18552.4 & 21504.9 & 19853.6 & 19913.2 \\
\hline 100.25 & 18619.5 & 21528.1 & 19899.7 & 19957.7 \\
\hline 100.5 & 18673.2 & 21551.6 & 19942.9 & 20002.4 \\
\hline 100.75 & 18725.7 & 21585.8 & 19985.3 & 20046.8 \\
\hline 101 & 18780.1 & 21616.7 & 20029.8 & 20091.5 \\
\hline 101.25 & 18832.9 & 21641.8 & 20071.9 & 20136.3 \\
\hline 101.5 & 18885.6 & 21671.5 & 20119.5 & 20180.5 \\
\hline 101.75 & 18929.3 & 21709.9 & 20165.3 & 20225.8 \\
\hline 102 & 18974.5 & 21743.9 & 20211.7 & 20271.1 \\
\hline 102.25 & 19019.2 & 21778 & 20260.6 & 20315.4 \\
\hline 102.5 & 19058.8 & 21824.7 & 20307 & 20360.4 \\
\hline 103 & 19097.6 & 21876.9 & 20350.2 & 20405.7 \\
\hline & 19137.1 & 21919.6 & 20392.6 & 20449.9 \\
\hline & & & \\
\hline
\end{tabular}




\begin{tabular}{|c|c|c|c|c|}
\hline 103.25 & 19175 & 21976.8 & 20436 & 20495.2 \\
\hline 103.5 & 19206.4 & 22040.2 & 20482.9 & 20540.3 \\
\hline 103.75 & 19238.9 & 22089.9 & 20529 & 20585.6 \\
\hline 104 & 19269.8 & 22157.1 & 20570.9 & 20630.1 \\
\hline 104.25 & 19296.2 & 22213.7 & 20614.2 & 20674.1 \\
\hline 104.5 & 19324.4 & 22279.9 & 20657.6 & 20719.7 \\
\hline 104.75 & 19355.1 & 22351.9 & 20701.4 & 20764.2 \\
\hline 105 & 19384.4 & 22416.3 & 20743.8 & 20808.2 \\
\hline 105.25 & 19486.7 & 22459 & 20798 & 20867.7 \\
\hline 105.5 & 19576 & 22493.6 & 20855.3 & 20926 \\
\hline 105.75 & 19657.9 & 22524.3 & 20913.5 & 20984.8 \\
\hline 106 & 19738.3 & 22559.2 & 20972.8 & 21044 \\
\hline 106.25 & 19815.4 & 22600.5 & 21035.7 & 21103.9 \\
\hline 106.5 & 19876.7 & 22638.8 & 21097.9 & 21163.6 \\
\hline 106.75 & 19938.7 & 22677.5 & 21163.6 & 21224.6 \\
\hline 107 & 19991.7 & 22729.2 & 21226.2 & 21284.3 \\
\hline 107.25 & 20051.4 & 22775.6 & 21287.5 & 21343.9 \\
\hline 107.5 & 20102.3 & 22826.1 & 21352.7 & 21404.6 \\
\hline 107.75 & 20149.8 & 22882.4 & 21415 & 21464.9 \\
\hline 108 & 20200.5 & 22924.3 & 21482.4 & 21524.8 \\
\hline 108.25 & 20246.1 & 22981.8 & 21541.3 & 21583.2 \\
\hline 108.5 & 20287.2 & 23048.8 & 21601.9 & 21643.6 \\
\hline 108.75 & 20333.8 & 23129.6 & 21661.6 & 21702.1 \\
\hline 109 & 20376 & 23215.5 & 21722.7 & 21761.9 \\
\hline 109.25 & 20411.6 & 23296.8 & 21780.4 & 21819.9 \\
\hline 109.5 & 20441.9 & 23381.2 & 21841.4 & 21879.2 \\
\hline 109.75 & 20475.6 & 23478.6 & 21898.9 & 21938 \\
\hline 110 & 20510.8 & 23579.1 & 21955.6 & 21997.1 \\
\hline 110.25 & 20632.9 & 23618.5 & 22035.7 & 22075.2 \\
\hline 110.5 & 20756.5 & 23656.2 & 22111.9 & 22154.7 \\
\hline 110.75 & 20888.1 & 23684.7 & 22189.6 & 22232.6 \\
\hline 111 & 21005.1 & 23726.2 & 22266.8 & 22311.6 \\
\hline 111.25 & 21114 & 23759.6 & 22347.1 & 22389.8 \\
\hline 111.5 & 21218.6 & 23801.1 & 22427.2 & 22470 \\
\hline 111.75 & 21327.2 & 23844.3 & 22510.9 & 22551 \\
\hline 112 & 21426.6 & 23897.5 & 22596.2 & 22632 \\
\hline 112.25 & 21523.7 & 23948.2 & 22679.7 & 22712.4 \\
\hline 112.5 & 21620.2 & 24000.8 & 22765.4 & 22793.4 \\
\hline 112.75 & 21689.9 & 24064.4 & 22848.1 & 22874.5 \\
\hline 113 & 21768.2 & 24122.6 & 22931.4 & 22954.7 \\
\hline 113.25 & 21833.9 & 24183.7 & 23017.2 & 23035.8 \\
\hline
\end{tabular}




\begin{tabular}{|c|c|c|c|c|}
\hline 113.5 & 21901.1 & 24270.6 & 23097.8 & 23116.1 \\
\hline 113.75 & 21949.3 & 24351.8 & 23181.1 & 23196.3 \\
\hline 114 & 22013.3 & 24439.7 & 23264.8 & 23277.9 \\
\hline 114.25 & 22061.7 & 24524.1 & 23348.1 & 23358.6 \\
\hline 114.5 & 22120.7 & 24612.6 & 23431.7 & 23439.7 \\
\hline 114.75 & 22169.5 & 24711.2 & 23514.3 & 23520.3 \\
\hline 115 & 22218.6 & 24823.1 & 23591.2 & 23598.6 \\
\hline 115.25 & 22342 & 24850.6 & 23656 & 23666 \\
\hline 115.5 & 22478 & 24883.5 & 23720.7 & 23733.1 \\
\hline 115.75 & 22588.6 & 24922.7 & 23787.3 & 23800.4 \\
\hline 116 & 22703.3 & 24958.4 & 23854.5 & 23867.3 \\
\hline 116.25 & 22810.7 & 24997.1 & 23922.9 & 23934.5 \\
\hline 116.5 & 22914.2 & 25041.6 & 23992.1 & 24002.2 \\
\hline 116.75 & 23004.3 & 25080.5 & 24064 & 24069.3 \\
\hline 117 & 23100.5 & 25123.6 & 24134.5 & 24136.9 \\
\hline 117.25 & 23186.4 & 25167.2 & 24199.6 & 24203.4 \\
\hline 117.5 & 23267.8 & 25209.6 & 24269.8 & 24271 \\
\hline 117.75 & 23347 & 25256.5 & 24339.8 & 24338.6 \\
\hline 118 & 23411.2 & 25309.4 & 24407.9 & 24405.8 \\
\hline 118.25 & 23471.2 & 25373.1 & 24478.4 & 24474.2 \\
\hline 118.5 & 23529.9 & 25441.7 & 24548.8 & 24542.1 \\
\hline 118.75 & 23582.9 & 25508.5 & 24619.3 & 24610.1 \\
\hline 119 & 23644.1 & 25595.8 & 24686.9 & 24677.7 \\
\hline 119.25 & 23702.5 & 25691.8 & 24755.8 & 24744.5 \\
\hline 119.5 & 23743.6 & 25774.3 & 24824.3 & 24811.6 \\
\hline 119.75 & 23800.9 & 25864.8 & 24891.8 & 24879.4 \\
\hline 120 & 23846.6 & 25963.6 & 24954.5 & 24946.2 \\
\hline 120.25 & 23936.9 & 25981 & 25005.8 & 24999.9 \\
\hline 120.5 & 24037.1 & 26007.7 & 25057.1 & 25054 \\
\hline 120.75 & 24131.5 & 26027.8 & 25108.5 & 25108.7 \\
\hline 121 & 24226 & 26056.1 & 25158.4 & 25162.9 \\
\hline 121.25 & 24312.1 & 26084.5 & 25211.9 & 25216.6 \\
\hline 121.5 & 24391 & 26108.7 & 25264.2 & 25271.4 \\
\hline 121.75 & 24471.5 & 26139.8 & 25316.8 & 25325.3 \\
\hline 122 & 24549.3 & 26176.4 & 25369.9 & 25379.7 \\
\hline 122.25 & 24625.4 & 26213.5 & 25423.2 & 25433.5 \\
\hline 122.5 & 24680.9 & 26259.8 & 25478.3 & 25488.3 \\
\hline 122.75 & 24748.2 & 26300.6 & 25534.6 & 25541.9 \\
\hline 123 & 24800.1 & 26356.4 & 25589.2 & 25595.7 \\
\hline 123.25 & 24851.3 & 26413 & 25643 & 25648.5 \\
\hline 123.5 & 24892.8 & 26472.9 & 25696 & 25701.7 \\
\hline
\end{tabular}




\begin{tabular}{|c|c|c|c|c|}
\hline 123.75 & 24931.8 & 26534 & 25750.3 & 25755.1 \\
\hline 124 & 24969.8 & 26604.5 & 25805.8 & 25808.8 \\
\hline 124.25 & 25000.7 & 26682.1 & 25857.9 & 25862.1 \\
\hline 124.5 & 25027.1 & 26768.2 & 25911.4 & 25916.1 \\
\hline 124.75 & 25061.4 & 26865.9 & 25963.2 & 25970.2 \\
\hline 125 & 25087.6 & 26955.2 & 26013.9 & 26023.2 \\
\hline 125.25 & 25159.4 & 26991.5 & 26057.9 & 26069.5 \\
\hline 125.5 & 25236.3 & 27006.8 & 26103.5 & 26117.3 \\
\hline 125.75 & 25302.2 & 27037.7 & 26151.1 & 26164.7 \\
\hline 126 & 25367.3 & 27063 & 26197.8 & 26212.7 \\
\hline 126.25 & 25437.7 & 27099.4 & 26246.1 & 26260.3 \\
\hline 126.5 & 25492.1 & 27133.4 & 26295.2 & 26308.4 \\
\hline 126.75 & 25542.3 & 27176.8 & 26343.4 & 26356.8 \\
\hline 127 & 25593 & 27218 & 26394.3 & 26404.9 \\
\hline 127.25 & 25639.3 & 27260.5 & 26446 & 26453.1 \\
\hline 127.5 & 25680.1 & 27313.4 & 26495.3 & 26500.3 \\
\hline 127.75 & 25719.3 & 27375.7 & 26542.9 & 26548.3 \\
\hline 128 & 25755.3 & 27436.3 & 26589.2 & 26595.9 \\
\hline 128.25 & 25784.2 & 27495.4 & 26632.3 & 26643.5 \\
\hline 128.5 & 25815 & 27559.1 & 26679.1 & 26691.6 \\
\hline 128.75 & 25848.1 & 27629.9 & 26725.5 & 26740.3 \\
\hline 129 & 25877.8 & 27706.3 & 26770.1 & 26787.6 \\
\hline 129.25 & 25902.1 & 27788.3 & 26818.4 & 26835.2 \\
\hline 129.5 & 25925.3 & 27862.4 & 26860.9 & 26882.7 \\
\hline 129.75 & 25948 & 27941.2 & 26902.7 & 26929.7 \\
\hline 130 & 25961.6 & 28021.5 & 26947.8 & 26976.1 \\
\hline 130.25 & 26030.6 & 28067.5 & 26997.5 & 27026.6 \\
\hline 130.5 & 26094.3 & 28113.2 & 27046.9 & 27077.8 \\
\hline 130.75 & 26149.5 & 28155.1 & 27095.5 & 27127.8 \\
\hline 131 & 26197.6 & 28197.4 & 27145.9 & 27178.3 \\
\hline 131.25 & 26245.5 & 28258.9 & 27199.8 & 27229.1 \\
\hline 131.5 & 26284.7 & 28310.5 & 27254.4 & 27279.3 \\
\hline 131.75 & 26323.2 & 28365.4 & 27305.3 & 27330.4 \\
\hline 132 & 26362.5 & 28427.5 & 27356.1 & 27381.5 \\
\hline 132.25 & 26395.8 & 28487.2 & 27403.5 & 27431.1 \\
\hline 132.5 & 26420.2 & 28554.4 & 27454.6 & 27480.7 \\
\hline 132.75 & 26451.3 & 28621.6 & 27498.6 & 27529.6 \\
\hline 133 & 26467.7 & 28698.4 & 27545.6 & 27578.1 \\
\hline 133.25 & 26495.3 & 28786.7 & 27590.7 & 27626.7 \\
\hline 133.5 & 26509.3 & 28871 & 27639.8 & 27674.8 \\
\hline 133.75 & 26533 & 28959.5 & 27687.3 & 27723.4 \\
\hline
\end{tabular}




\begin{tabular}{|c|c|c|c|c|}
\hline 134 & 26549.4 & 29054 & 27730 & 27773.2 \\
\hline 134.25 & 26568.4 & 29145.1 & 27775 & 27821.3 \\
\hline 134.5 & 26582.8 & 29252.7 & 27817.1 & 27869.9 \\
\hline 134.75 & 26601.6 & 29359.6 & 27863 & 27918.7 \\
\hline 135 & 26624.4 & 29475.7 & 27900.9 & 27967.9 \\
\hline 135.25 & 26677.3 & 29499.2 & 27952.1 & 28014.6 \\
\hline 135.5 & 26731 & 29526.7 & 28000.4 & 28062.7 \\
\hline 135.75 & 26785.6 & 29554.2 & 28045.9 & 28109.7 \\
\hline 136 & 26840.8 & 29585 & 28094.7 & 28157.4 \\
\hline 136.25 & 26883.8 & 29625.6 & 28140.1 & 28205.4 \\
\hline 136.5 & 26937.6 & 29669.5 & 28190.1 & 28253.2 \\
\hline 136.75 & 26973.5 & 29713 & 28244.4 & 28300.8 \\
\hline 137 & 27018.5 & 29760.3 & 28297.6 & 28347.2 \\
\hline 137.25 & 27055.4 & 29808.3 & 28349.6 & 28395.5 \\
\hline 137.5 & 27093.4 & 29868.2 & 28399.7 & 28442.7 \\
\hline 137.75 & 27132 & 29914.7 & 28457.4 & 28491.9 \\
\hline 138 & 27159.5 & 29974.1 & 28507.2 & 28538.6 \\
\hline 138.25 & 27198.2 & 30031.1 & 28554 & 28586.5 \\
\hline 138.5 & 27224.4 & 30081.6 & 28607.2 & 28633.3 \\
\hline 138.75 & 27253 & 30150 & 28656.9 & 28681.2 \\
\hline 139 & 27279.5 & 30213.9 & 28701.8 & 28729 \\
\hline 139.25 & 27305.5 & 30293.3 & 28750.7 & 28777 \\
\hline 139.5 & 27328.9 & 30369.9 & 28797.9 & 28824.5 \\
\hline 139.75 & 27354.2 & 30448.7 & 28842.2 & 28873.6 \\
\hline 140 & 27379.8 & 30532.6 & 28888.3 & 28921.8 \\
\hline 140.25 & 27451.4 & 30557.5 & 28935.7 & 28967.6 \\
\hline 140.5 & 27524.4 & 30581.8 & 28978.9 & 29014.9 \\
\hline 140.75 & 27582.3 & 30608.4 & 29024.9 & 29061.7 \\
\hline 141 & 27658.8 & 30634.6 & 29073.5 & 29109.1 \\
\hline 141.25 & 27723.2 & 30661.8 & 29120.5 & 29155.9 \\
\hline 141.5 & 27792.2 & 30685.3 & 29166.2 & 29202.6 \\
\hline 141.75 & 27853.4 & 30715.7 & 29215.8 & 29248.9 \\
\hline 142 & 27896.2 & 30744.4 & 29268.1 & 29297.2 \\
\hline 142.25 & 27952.8 & 30783 & 29317.1 & 29343.3 \\
\hline 142.5 & 27998 & 30814.1 & 29364.3 & 29390.4 \\
\hline 142.75 & 28044 & 30845.5 & 29415.6 & 29437.1 \\
\hline 143 & 28078.6 & 30886.6 & 29464.2 & 29483.8 \\
\hline 143.25 & 28123.4 & 30925.8 & 29516.2 & 29531.8 \\
\hline 143.5 & 28154.6 & 30971.6 & 29568.2 & 29579.1 \\
\hline 143.75 & 28195.3 & 31009.2 & 29614.1 & 29625.7 \\
\hline 144 & 28238 & 31061.2 & 29663.9 & 29671.9 \\
\hline
\end{tabular}




\begin{tabular}{|r|r|r|r|r|}
\hline 144.25 & 28278.5 & 31113.9 & 29711.2 & 29719 \\
\hline 144.5 & 28308.9 & 31170.8 & 29757.1 & 29763.5 \\
\hline 144.75 & 28341.6 & 31223.5 & 29801.8 & 29809.1 \\
\hline 145 & 28364.5 & 31284.7 & 29844.8 & 29854.4 \\
\hline
\end{tabular}




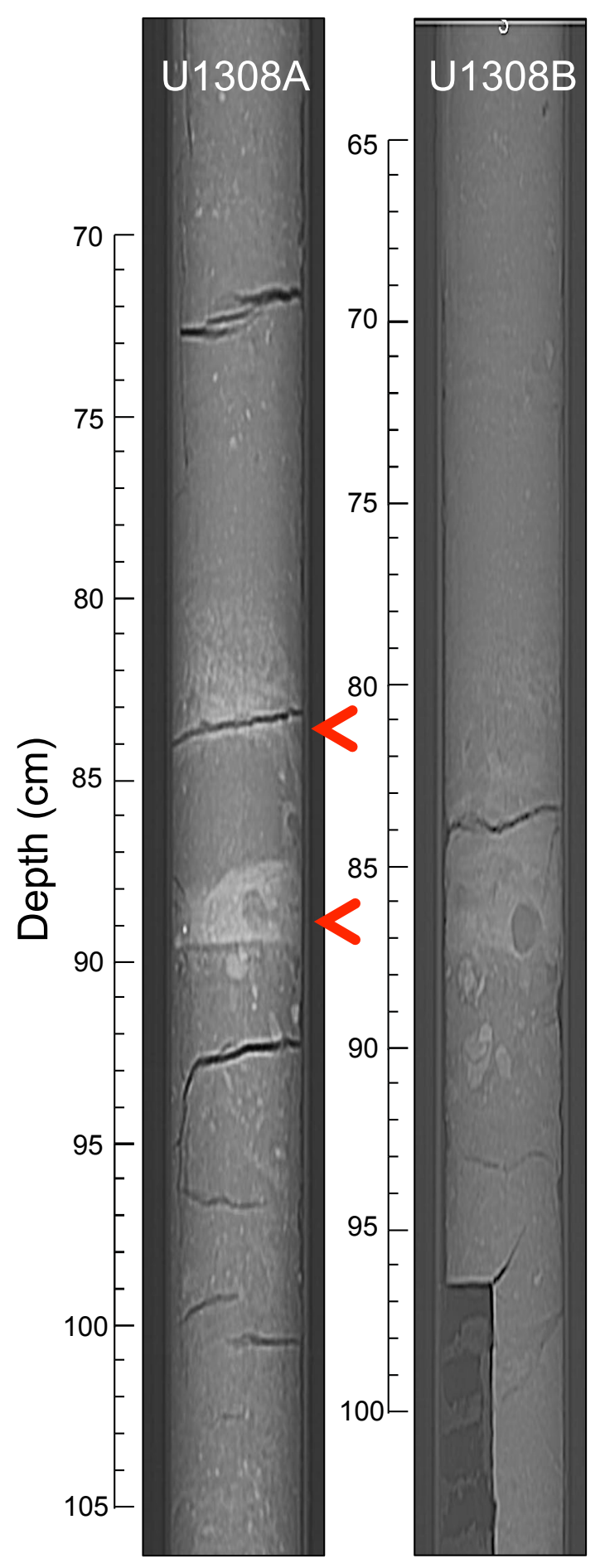

Figure S1. Overview (scout) X-ray CT scans of Section 1 in Holes U1308A and U1308B. Two distinct layers of dense sediment are visible in Hole U1308A (red arrows) whereas a single mixed layer occurs in Hole U1308B. 


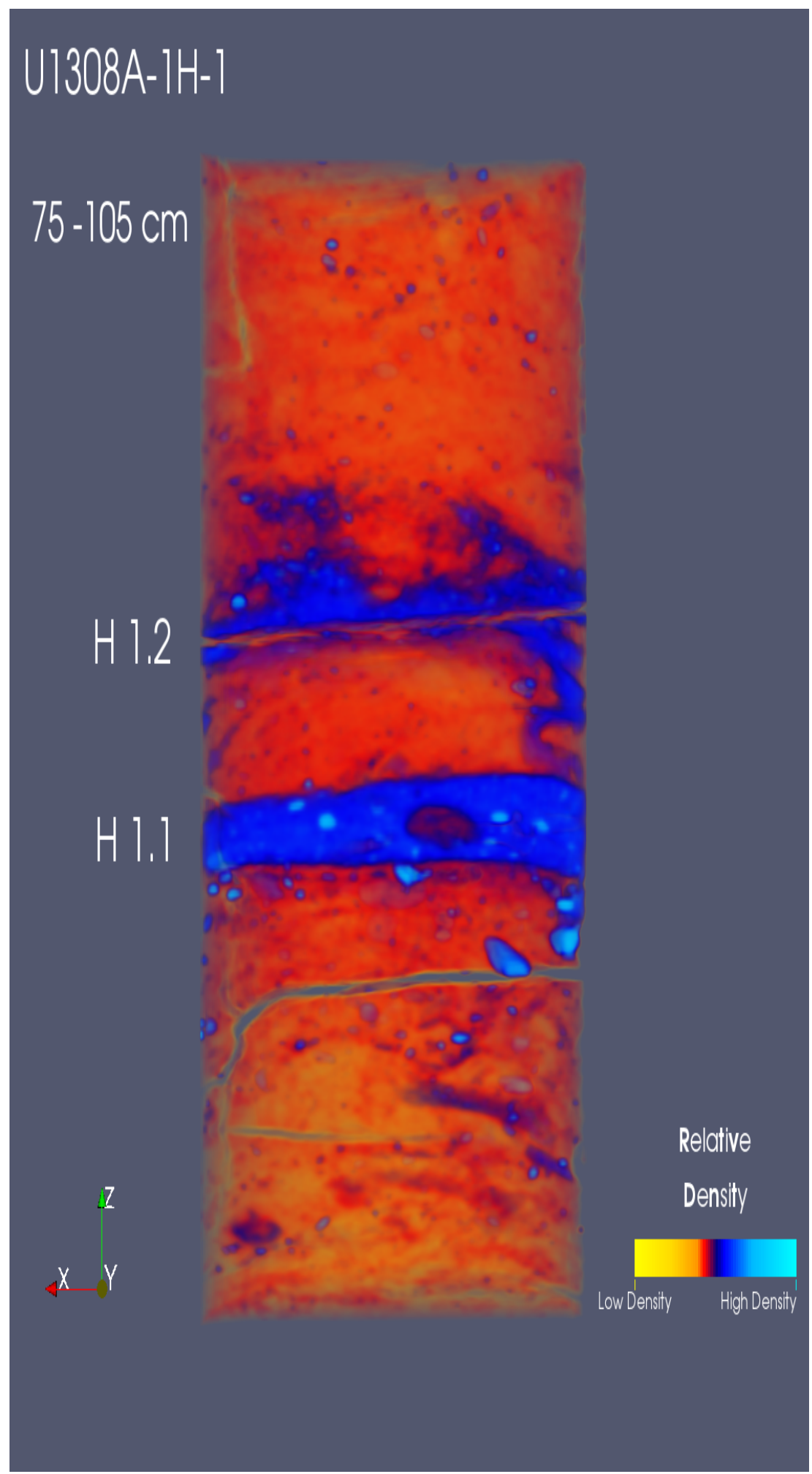

Figure S2. Frame shot of Movie S1 for Section U1308A-1H-1, 75-105 cm. Note the two distinct high-density layers associated with H1.1 and H1.2. 


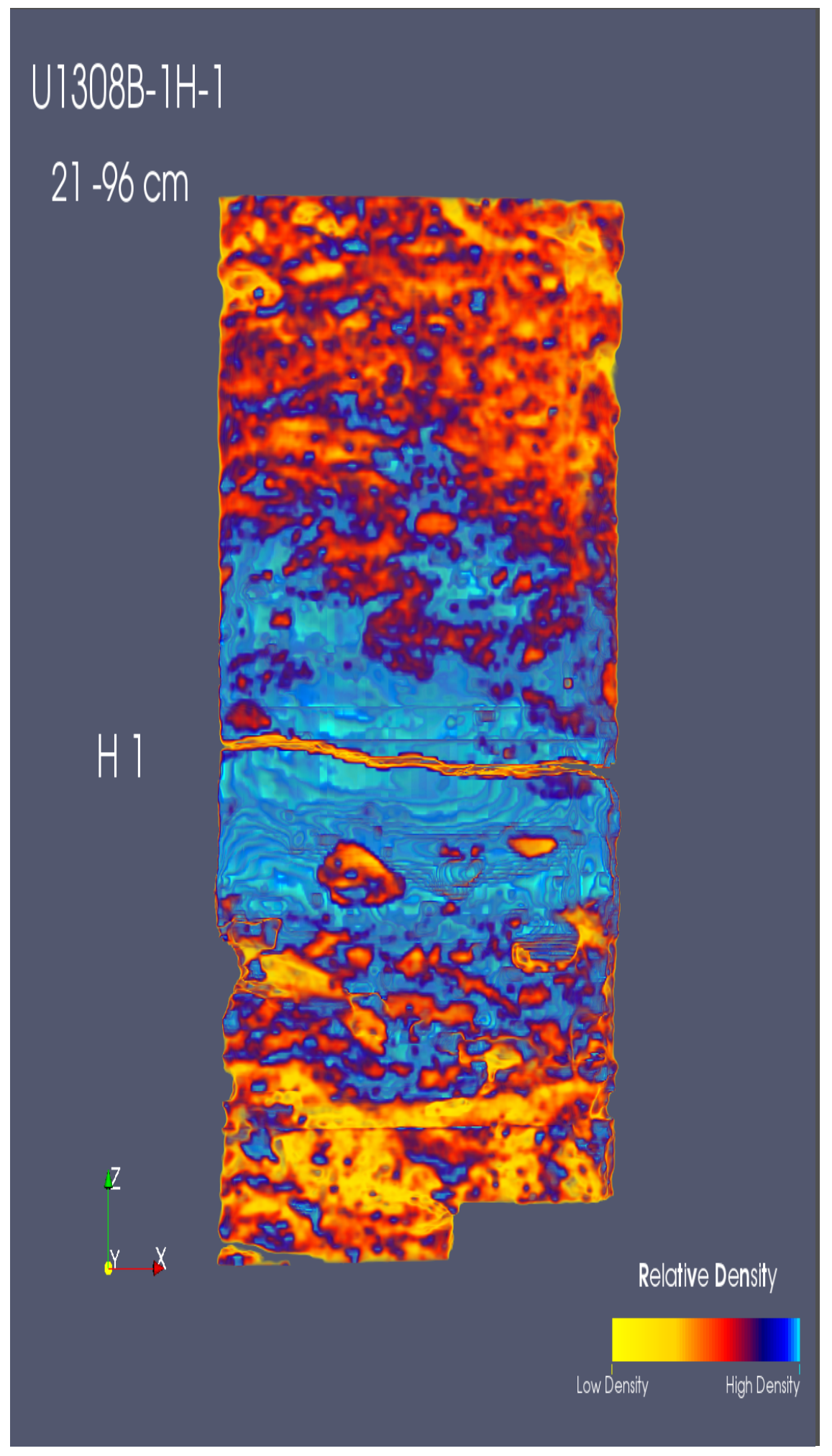

Figure S3. Frame shot of Movie S2 for Section U1308B-1H-1, 21-96 cm. Note that bioturbation has obliterated the internal structure of $\mathrm{H} 1$ in this hole. 


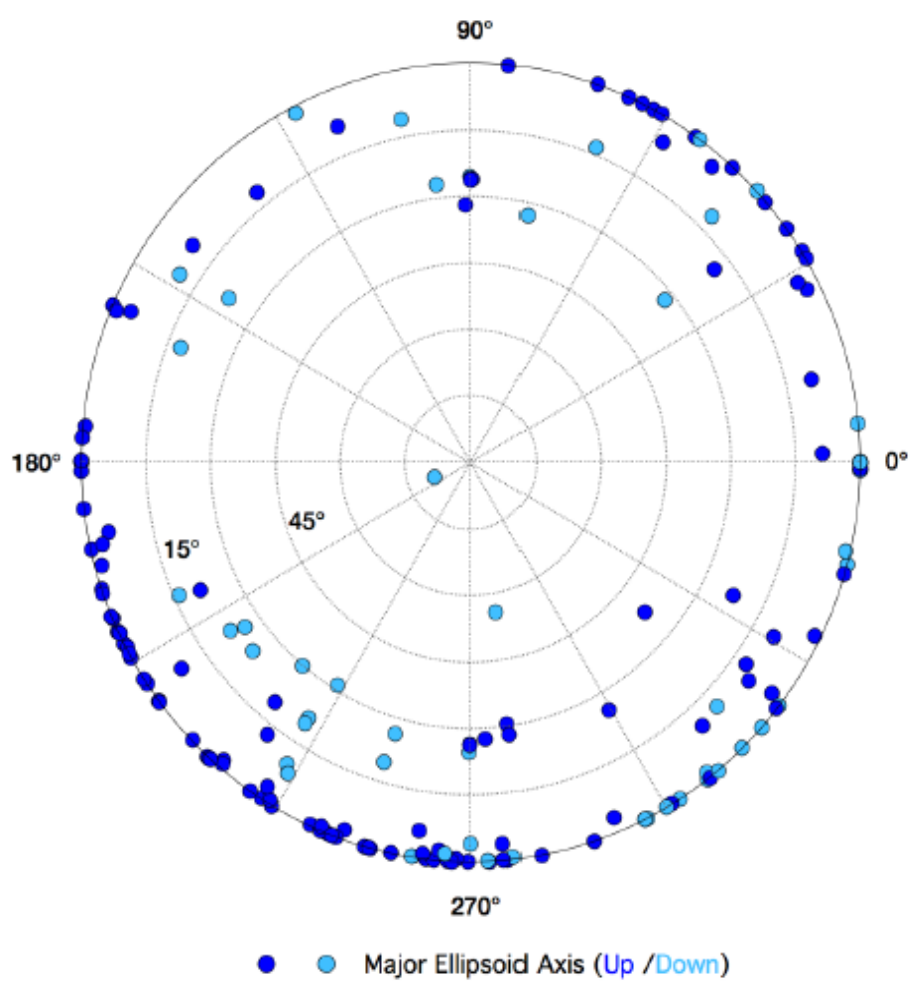

Figure S4. Stereonet of the major ellipsoid axes of the IRD grains in the CT scan of Section U1308A-1 H-1. The distribution indicates that the majority of the ellipsoid axes are oriented vertically upwards. 


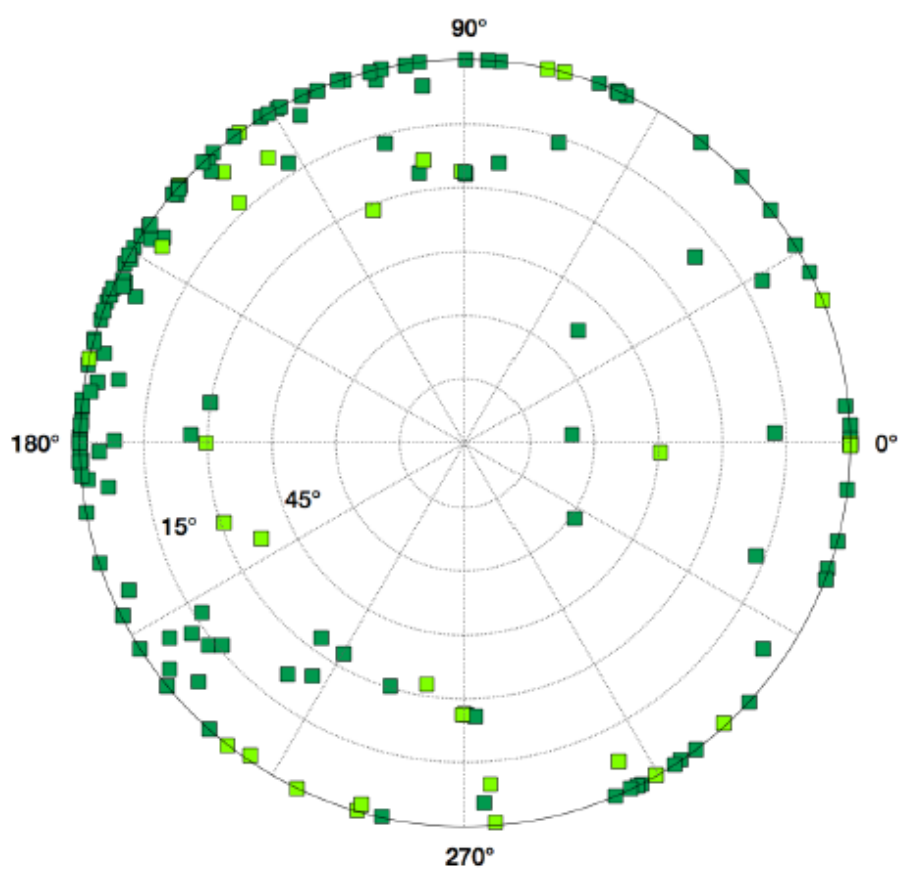

$\square \quad \square \quad$ Intermediate Ellipsoid Axis (Up /Down

Figure S5. Stereonet of the intermediate ellipsoid axes of the IRD grains in the CT scan of Section U1308A-1H-1. The orientation of the intermediate ellipsoid axes indicates that most grains lie parallel to the sea floor. 


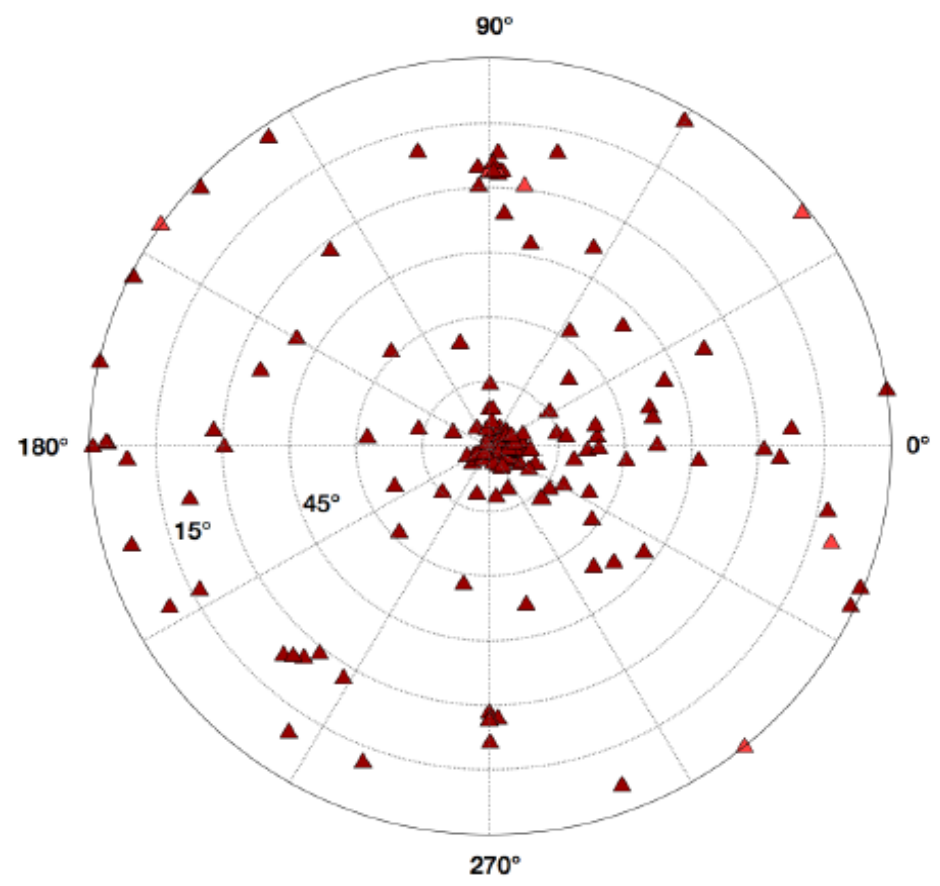

- $\Delta$ Minor Ellipsoid Axis (Up /Down)

Figure S6. Stereonet of the minor ellipsoid axes of the IRD grains in the CT scan of Section U1308A-1 $\mathrm{H}-1$. The orientation of the minor ellipsoid axes indicates that most grains lie parallel to the sea floor. 


\section{$609 *$ $1 \mathrm{H}-1$}
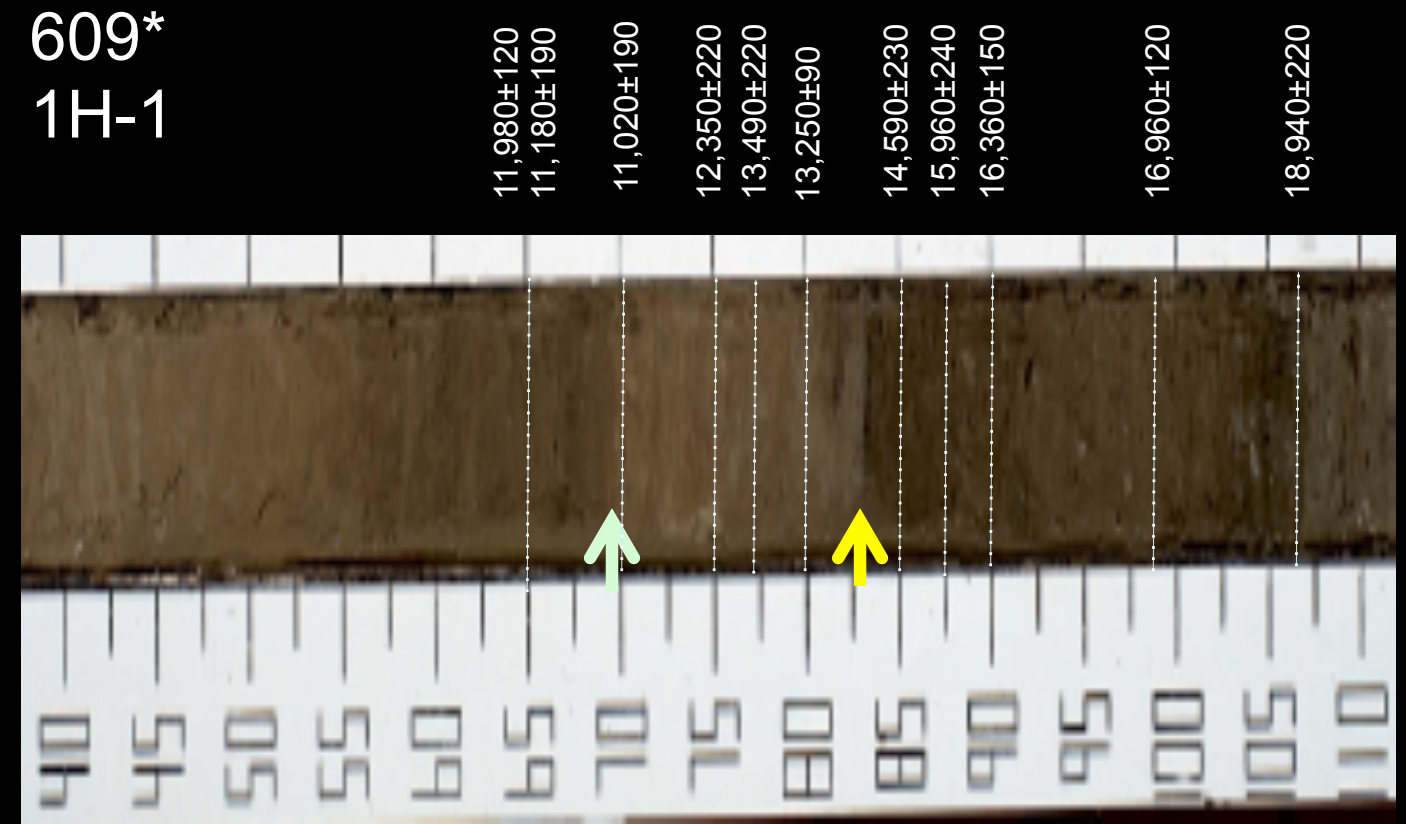

\section{B}

\section{$1 \mathrm{H}-1$}

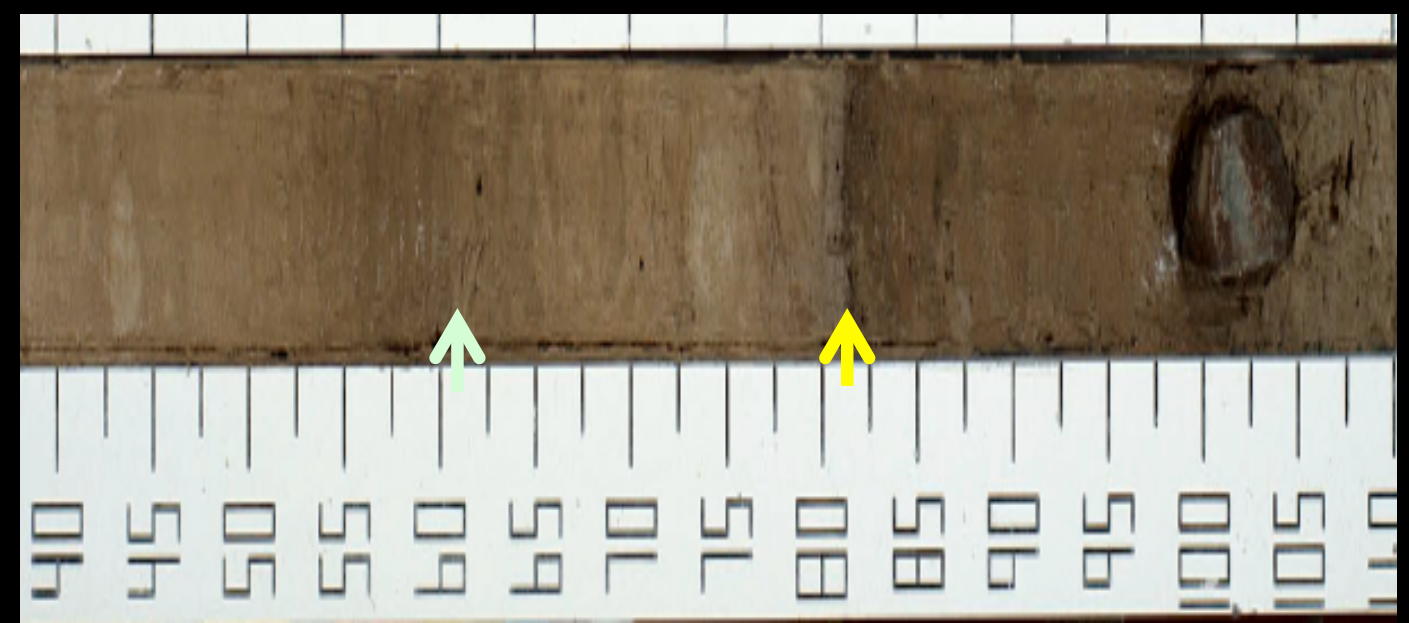

\section{figS07}

Figure S7. Core photos of Sections $609-1 \mathrm{H}-1$ and 609B-1H-1 indicating the positions of radiocarbon dates (dashed lines). Yellow arrows indicate the base of Heinrich Layer 1 and green arrows the base of the Younger Dryas. The images are similar to those of Site U1308 (Fig. 2). 

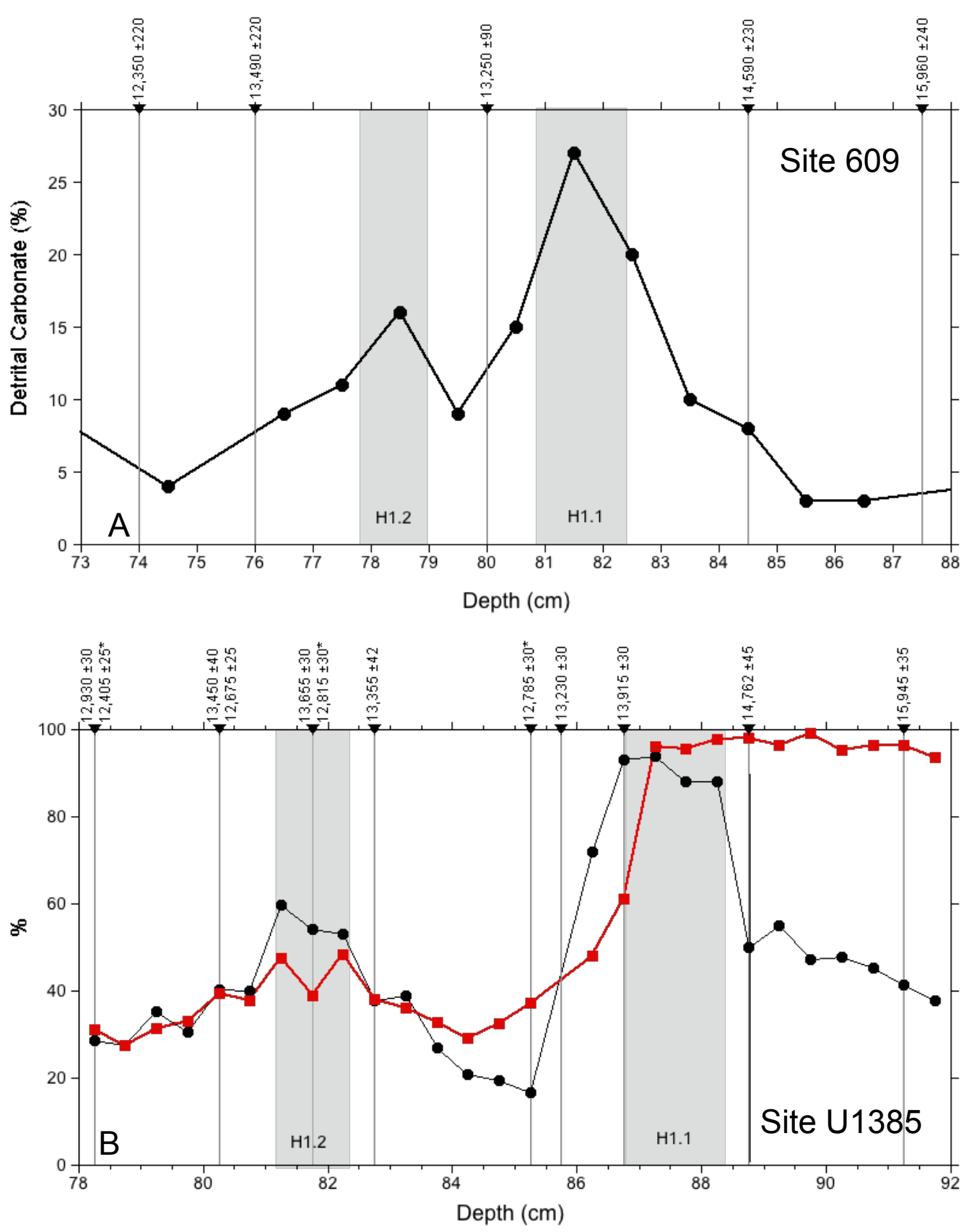

Figure S8 (A.) Percent detrital carbonate at Site 609 (black) [Bond et al., 1992] with position of radiocarbon dates indicated by vertical lines. (B.) Percent IRD (black) and N. pachyderma (sin) (red) in Section U1308A-1H-1 relative to the position of radiocarbon dates. The position of HL1.1 and HL 1.2 are indicated by gray shading. Note the similarity of the radiocarbon ages at the base of the two detrital carbonate peaks. 


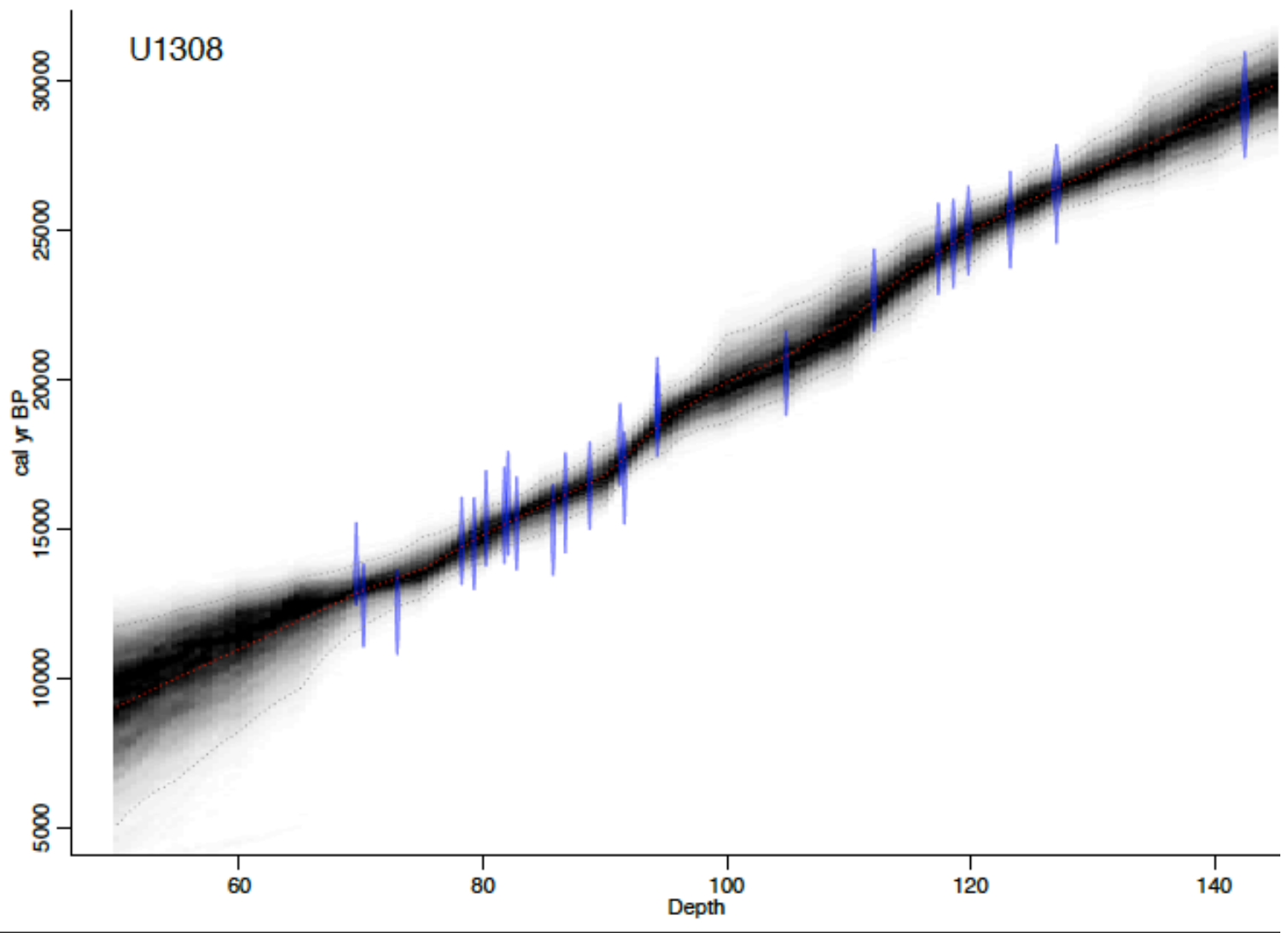

Figure S9. Calibrated radiocarbon dates (blue vertical lines) and the age-depth model using Bacon v. 2.2 versus depth (cm) in Section U1308A-1H-1. Darker greys indicate more likely calendar ages; grey stippled lines show $95 \%$ confidence intervals; red curve shows single 'best' model based on the weighted mean age for each depth. 


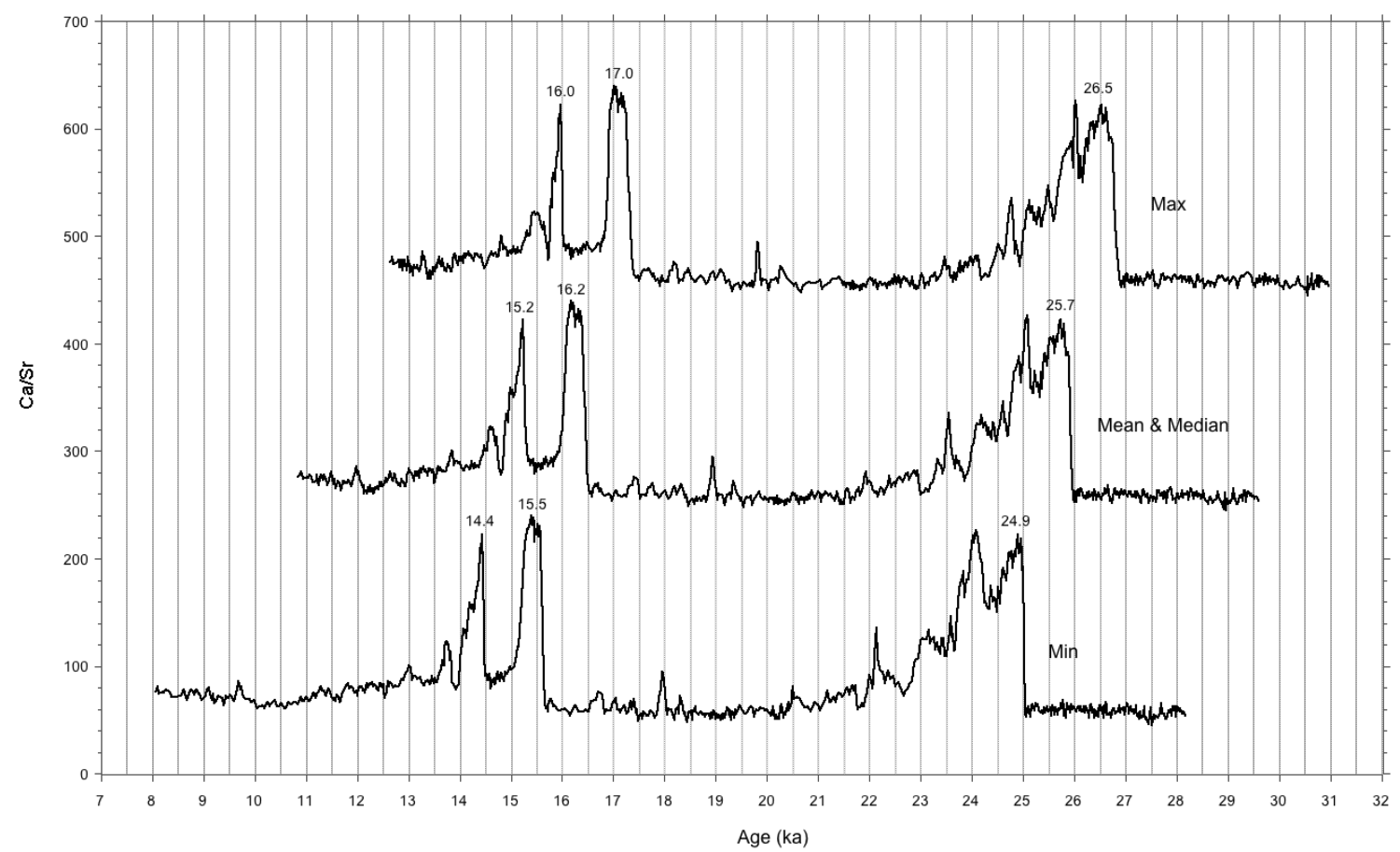

Figure S10. Ca/Sr record for Section U1308A-1H-1 using the minimum, mean/median, and maximum ages estimated using Bacon. The mean and median ages were indistinguishable from one another and are plotted together. The ages of the peaks are given for $\mathrm{H} 1.1, \mathrm{H} 1.2$ and $\mathrm{H} 2$. 


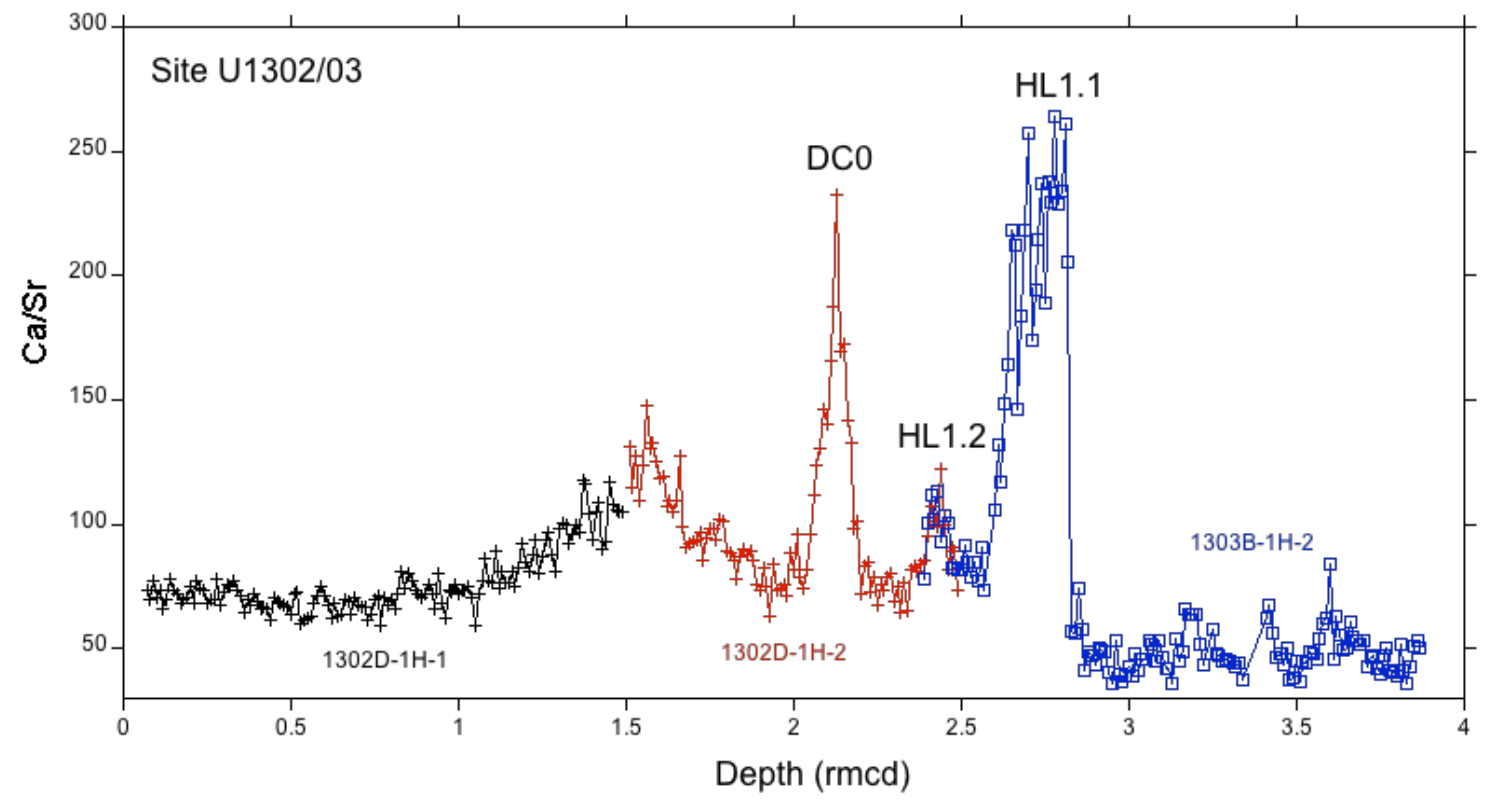

Figure S11. Ca/Sr from IODP Site U1302/03 located in a water depth of 3600m on Orphan Knoll. DCO $=$ Detrital Carbonate Event 0 associated with the Younger Dryas. The small $\mathrm{Ca} / \mathrm{Sr}$ peak between HL1.1 and DC0 might represent HL1.2. 

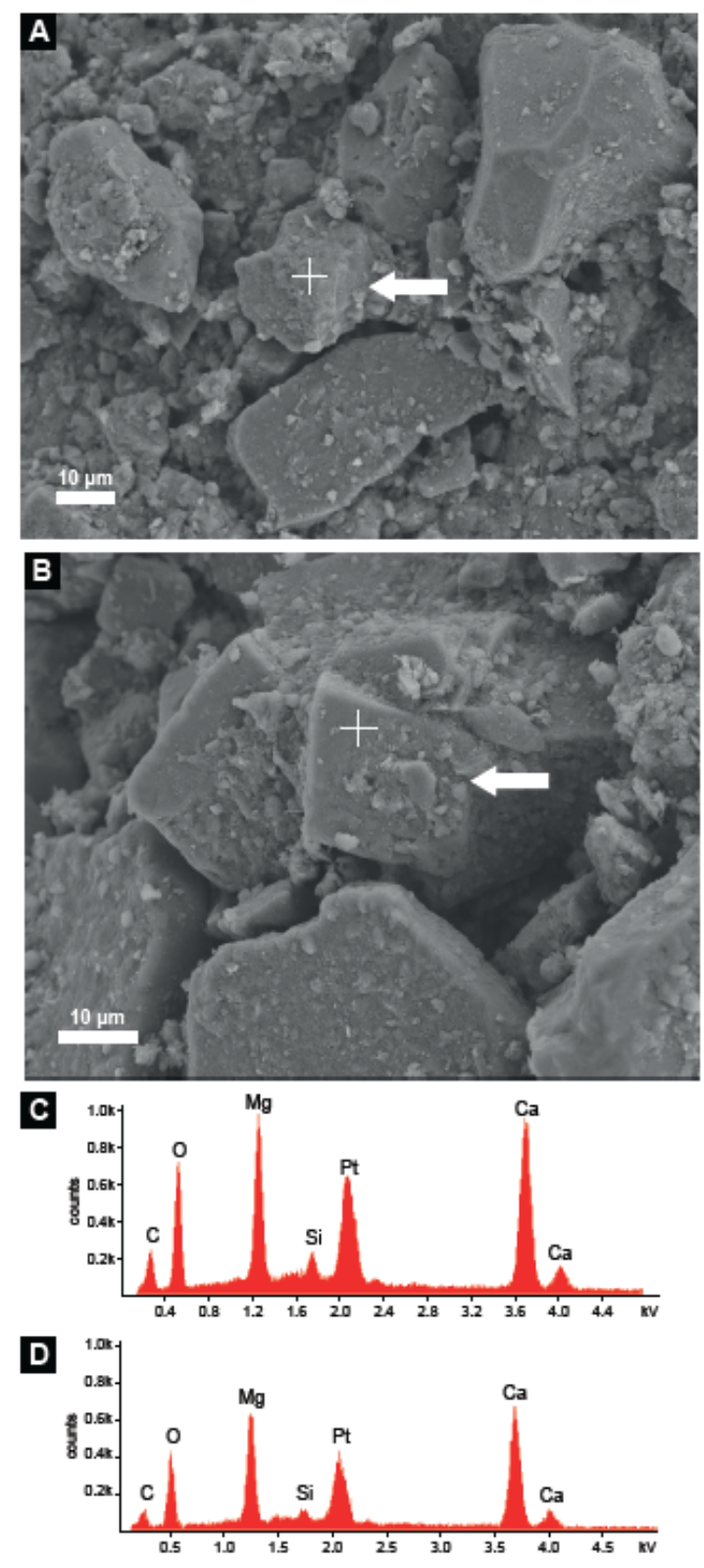

Figure S11. Scanning electron microscopy (SEM) photomicrographs showing that both detrital and authigenic dolomite is present in Heinrich layers. (A) Particle of detrital dolomite (arrow) characterized by irregular surfaces that likely result from mechanical reworking and transport. (B) Crystal displaying a rhombohedral habit (arrow) that commonly characterizes authigenic dolomite. The preservation of the rhombohedral crystals suggests that part of the dolomite present in the sample has not been transported but, rather, precipitated in situ, contributing in the cementation of the detrital carbonate particles (Tamburini et al., 2002). (C) and (D) Energy dispersive X-ray analyses confirming the dolomitic composition of the investigated minerals. The position of the spot analysis is indicated by the white cross in (A) for spectrum (C) and by the white cross in (B) for spectrum (D). The Si peaks are likely due to the presence of small clay minerals that stick to the dolomite, contaminating the EDX signal. Pt peaks correspond to coating applied during sample preparation. Analyses were performed with a Zeiss Supra 50 VP equipped with an energy dispersive $X$-ray detector for element 
analysis, using a secondary electron detector, applying an accelerating voltage of $15 \mathrm{kV}$, and a working distance of $7.5 \mathrm{~mm}$.

Data Set S1. Visualization of sediment coarse fraction $(>150 \mu \mathrm{m})$ at 1-cm intervals between 78 and $91 \mathrm{~cm}$ in Section U1308A-1H-1 at 10X magnification.

Data Set S2. Visualization of sediment coarse fraction $(>150 \mu \mathrm{m})$ for $78,82,85,87$, and $91 \mathrm{~cm}$ in Section U1308A-1H-1 at 62.5X magnification.

Data Set S3. Visualization of sediment coarse fraction $(>150 \mu \mathrm{m})$ for $78,82,85,87$, and $91 \mathrm{~cm}$ in Section U1308A-1H-1 at 125X magnification.

Movie S1. Movie of Section U1308A-1 H-1, 75-105 cm showing two distinct high-density layers associated with $\mathrm{H} 1.1$ and $\mathrm{H} 1.2$.

Movie S2. Movie for Section U1308B-1H-1, 21-96 cm. Note that bioturbation has obliterated the internal structure of $\mathrm{H} 1$ in this hole. 